\title{
Marine Pharmacology in 2014-2015: Marine Compounds with Antibacterial, Antidiabetic, Antifungal, Anti-Inflammatory, Antiprotozoal, Antituberculosis, Antiviral, and Anthelmintic Activities; Affecting the Immune and Nervous Systems, and Other Miscellaneous Mechanisms of Action
}

\author{
Alejandro M. S. Mayer ${ }^{1, *}$, Aimee J. Guerrero ${ }^{1}$, Abimael D. Rodríguez ${ }^{2}$, \\ Orazio Taglialatela-Scafati ${ }^{3} \mathbb{D}$, Fumiaki Nakamura ${ }^{4}$ and Nobuhiro Fusetani ${ }^{5}$ \\ 1 Department of Pharmacology, College of Graduate Studies, Midwestern University, 555 31st Street, \\ Downers Grove, IL 60515, USA; aguerrero89@midwestern.edu \\ 2 Molecular Sciences Research Center, University of Puerto Rico, 1390 Ponce de León Avenue, \\ San Juan, PR 00926, USA; abimael.rodriguez1@upr.edu \\ 3 Department of Pharmacy, University of Naples "Federico II", Via D. Montesano 49, I-80131 Napoli, Italy; \\ scatagli@unina.it \\ 4 Department of Chemistry and Biochemistry, Graduate School of Advanced Science and Engineering, \\ Waseda University, 3-4-1 Okubo, Shinjuku-ku, Tokyo 169-8555, Japan; what-will_be.x2@akane.waseda.jp \\ $5 \quad$ Fisheries and Oceans Hakodate, Hakodate 041-8611, Japan; anobu@fish.hokudai.ac.jp \\ * Correspondence: amayer@midwestern.edu; Tel.: +1-630-515-6951; Fax: +1-630-515-6295
}

Received: 27 November 2019; Accepted: 14 December 2019; Published: 19 December 2019

\begin{abstract}
The systematic review of the marine pharmacology literature from 2014 to 2015 was completed in a manner consistent with the 1998-2013 reviews of this series. Research in marine pharmacology during 2014-2015, which was reported by investigators in 43 countries, described novel findings on the preclinical pharmacology of 301 marine compounds. These observations included antibacterial, antifungal, antiprotozoal, antituberculosis, antiviral, and anthelmintic pharmacological activities for 133 marine natural products, 85 marine compounds with antidiabetic, and anti-inflammatory activities, as well as those that affected the immune and nervous system, and 83 marine compounds that displayed miscellaneous mechanisms of action, and may probably contribute to novel pharmacological classes upon further research. Thus, in 2014-2015, the preclinical marine natural product pharmacology pipeline provided novel pharmacology as well as new lead compounds for the clinical marine pharmaceutical pipeline, and thus continued to contribute to ongoing global research for alternative therapeutic approaches to many disease categories.
\end{abstract}

Keywords: drug; marine; chemical; metabolite; natural product; pharmacology; pharmaceutical; review; toxicology; pipeline

\section{Introduction}

The aim of the present review is to consolidate 2014-2015 preclinical marine pharmacology, with a format similar to the previous nine reviews of this series, which cover the period 1998-2013 [1-9]. The peer-reviewed articles were retrieved from searches in the following databases: MarinLit, PubMed, Chemical Abstracts ${ }^{\circledR}$, ISI Web of Knowledge, and Google Scholar. As in our previous work, we have limited our review to include bioactivity and/or pharmacology of structurally characterized marine 
chemicals, which we have classified using a modification of Schmitz's chemical classification [10] into six major chemical classes, namely, polyketides, terpenes, peptides, alkaloids, shikimates, and sugars. The preclinical antibacterial, antifungal, antiprotozoal, antituberculosis, antiviral, and anthelmintic pharmacology of marine chemicals is reported in Table 1, with the structures shown in Figure 1. Marine compounds that affected the immune and nervous systems, with antidiabetic and anti-inflammatory effects, are exhibited in Table 2, with their respective structures consolidated in Figure 2. Finally, marine compounds affecting a variety of cellular and molecular targets are noted in Table 3 , and their structures are shown in Figure 3.

Several publications during 2014-2015 reported on several marine extracts or structurally uncharacterized compounds, with novel preclinical and/or clinical pharmacology: in vitro phenotype-guided the discovery of natural products using cytological profiling to predict modes of action of bioactive constituents in extracts [11]; Colombian and Brazilian marine organisms as source of antibacterial extracts with bacterial quorum sensing inhibitory activity [12]; a first report describing antimicrobial activity in extracts from cultivable fungi associated with Antarctic marine sponges [13]; an extensive study on the antimicrobial activity of crude extracts from several species of red algae from Madagascar [14]; bioactive compounds along with a purified macrolactin with broad spectrum antibacterial activity in crude extracts from B. subtilis MTCC10403 associated with the Indian brown seaweed A. longifolius [15]; potential $\beta$-lactamase inhibitory activity in a Bay of Bengal marine Streptomyces sp. PM49 with antibacterial properties on multidrug-resistant pathogens [16]; in vitro anti-inflammatory activity of an extract and individual components in the spiny seastar M. glacialis that inhibited "different levels of the inflammation pathway" [17]; in vitro anti-inflammatory activity of several galactolipids isolated from methanol extracts of cultivated red alga Chondrus crispus that were proposed "to counter inflammation associated with NO-mediated disorders" [18]; in vitro immunomodulatory activity of an extract of the Bohai sea ascidian Styela clava that exhibited proliferative activity and promoted nitric oxide (NO) release from mouse lymphocytes and macrophages [19]; in vivo anti-inflammatory activity of a new nucleoside, dragmacidoside isolated from an extract of a marine Red sea sponge Dragmacidon coccinea [20]; in vivo anti-inflammatory and analgesic activities of an organic extract and its semipurified fractions from the Tunisian gorgonian Eunicella singularis, which suggested that "components of the active fraction can be used to treat various anti-inflammatory diseases" [21]; in vitro anti-inflammatory activity of 30 compounds in a methanol extract of the digestive gland of the Mediterranean sea hare Aplysia depilans, which could provide "beneficial anti-inflammatory effects" [22]; and, as part of anti-obesity nutraceuticals research, the anti-adipogenic activity of phlorotannins isolated from the edible brown alga Ecklonia cava were reported to be a "promising source for utilization against obesity and related complications" [23].

2. Marine Compounds with Antibacterial, Antifungal, Antiprotozoal, Antituberculosis, Antiviral, and Anthelmintic Activities

Table 1 presents 2014-2015 preclinical pharmacological research on the antibacterial, antifungal, antiprotozoal, antituberculosis, antiviral, and anthelmintic activities of marine natural products (1-133) shown in Figure 1. 
Table 1. Marine pharmacology in 2014-2015: marine compounds with antibacterial, antifungal, antituberculosis, antiprotozoal, antiviral, and anthelmintic activities.

\begin{tabular}{|c|c|c|c|c|c|c|c|}
\hline Drug Class & Compound/Organism ${ }^{a}$ & Chemistry & Pharmacologic Activity & $\mathrm{IC}_{50} \mathrm{~b}$ & MMOA $^{b}$ & Country $^{c}$ & References \\
\hline Antibacterial & axinellamines $\mathrm{A}$ and $\mathrm{B}(\mathbf{1}, \mathbf{2}) /$ sponge & Alkaloid $^{\mathrm{f}}$ & Gram-positive and negative inhibition & $0.5-32 \mu \mathrm{g} / \mathrm{mL}^{+}$ & $\begin{array}{l}\text { Normal cellular } \\
\text { division inhibition }\end{array}$ & USA & {$[24]$} \\
\hline Antibacterial & buanmycin (3)/bacterium & Polyketide $^{\mathrm{d}}$ & S. enterica inhibition & $0.7 \mu \mathrm{M}^{+}$ & Sortase A inhibition & S. KOR & [25] \\
\hline Antibacterial & cathelicidin (4)/sea snake & Peptide ${ }^{f}$ & Gram-positive and negative inhibition & $0.16-20.7 \mu \mathrm{g} / \mathrm{mL}^{+}$ & $\begin{array}{l}\text { Membrane } \\
\text { morphology } \\
\text { alteration }\end{array}$ & $\mathrm{CHN}$ & [26] \\
\hline Antibacterial & clavanin A (5)/ascidian & Peptide $^{\mathrm{f}}$ & S. aureus and E. coli infection inhibition & $10 \mathrm{mg} / \mathrm{kg}^{* * *}$ & $\begin{array}{l}\text { IL- } 6 \text { and TNF- } \alpha \\
\text { inhibition }\end{array}$ & BRA & [27] \\
\hline Antibacterial & gelliusterol E (6)/sponge & Terpenoid $^{\mathrm{e}}$ & C. trachomatis inhibition & $2.34 \mu \mathrm{M}$ & $\begin{array}{l}\text { OmpA protein } \\
\text { inhibition }\end{array}$ & EGY, GBR & {$[28]$} \\
\hline Antibacterial & $\begin{array}{l}\text { ianthelliformisamimes B and C ( } 7 \text {, } \\
8) / \text { sponge }\end{array}$ & Alkaloid $^{\mathrm{f}}$ & $\begin{array}{l}\text { Enhanced antibiotics against } E \text {. } \\
\text { aerogenes, P. aeruginosa, K. Pneumoniae } \\
\text { MDR strains in vitro }\end{array}$ & $3.12-12.5 \mu \mathrm{M}$ * & $\begin{array}{l}\text { Enhancement of } \\
\text { drug transporters }\end{array}$ & FRA & [29] \\
\hline Antibacterial & pardaxin (9)/flatfish & Peptide $^{\mathrm{f}}$ & MR S. aureus inhibition in vivo & $8 \mathrm{mg} / \mathrm{mL}^{*}$ & $\begin{array}{l}\text { MCP-1, IL-6, and } \\
\text { TNF- } \alpha \text { inhibition }\end{array}$ & TWN & {$[30]$} \\
\hline Antibacterial & phlorofucofuroeckol-A (10)/alga & Polyketide $^{\mathrm{d}}$ & MR S. aureus inhibition & $32 \mu \mathrm{g} / \mathrm{mL}^{+}$ & PBP2a suppresion & S. KOR & [31] \\
\hline Antibacterial & salinamide $\mathrm{F}(\mathbf{1 1}) /$ bacterium & Peptide $^{\mathrm{f}}$ & E. coli inhibition & $0.2 \mu \mathrm{g} / \mathrm{mL}^{+}$ & RNAP inhibition & USA & [32] \\
\hline Antibacterial & piscidins $(\mathbf{1 2}, \mathbf{1 3}) /$ fish & Peptide ${ }^{f}$ & $\begin{array}{l}\text { K. pneumonia and A. baumannii } \\
\text { inhibition in vitro }\end{array}$ & $1.5-3.1 \mu \mathrm{M}^{+}$ & Undetermined & TWN & {$[33]$} \\
\hline Antibacterial & adametizine $\mathrm{A}(\mathbf{1 4}) /$ fungus & Terpenoid $^{\mathrm{e}}$ & S. aureus inhibition & $8 \mu \mathrm{g} / \mathrm{mL}^{+}$ & Undetermined & $\mathrm{CHN}$ & [34] \\
\hline Antibacterial & agelamadins $\mathrm{A}$ and $\mathrm{B}(\mathbf{1 5}, \mathbf{1 6}) /$ sponge & Alkaloid $^{\mathrm{f}}$ & M. luteus and C. neoformans inhibition & $5-8 \mu \mathrm{g} / \mathrm{mL}^{+}$ & Undetermined & AUS, JPN & [35] \\
\hline Antibacterial & $\begin{array}{l}\text { Aspergillus sp. butyrolactone } \\
\text { (17)/fungus }\end{array}$ & Terpenoid $^{\mathrm{e}}$ & S. aureus and B. cereus inhibition & $1.56 \mu \mathrm{M}^{+}$ & Undetermined & $\mathrm{CHN}$ & [36] \\
\hline Antibacterial & aszonapyrone A (18)/fungus & Terpenoid $^{\mathrm{e}}$ & S. aureus and B. subtilis inhibition & $8 \mu \mathrm{g} / \mathrm{mL}^{+}$ & Undetermined & PRT, THAI & {$[37]$} \\
\hline Antibacterial & austalide R (19)/fungus & Terpenoid $^{\mathrm{e}}$ & Marine bacteria inhibition & $0.1 \mu \mathrm{g} / \mathrm{mL}^{+}$ & Undetermined & $\begin{array}{l}\text { CHN, DEU, } \\
\text { GBR }\end{array}$ & [38] \\
\hline Antibacterial & citrifelin B (20)/fungus & Polyketide $^{\mathrm{d}}$ & S. aureus inhibition & $4 \mu \mathrm{g} / \mathrm{mL}^{+}$ & Undetermined & $\mathrm{CHN}$ & [39] \\
\hline Antibacterial & desmethylisaridin C1 (21)/fungus & Peptide $^{f}$ & E. coli inhibition & $8 \mu \mathrm{g} / \mathrm{mL}$ & Undetermined & $\mathrm{CHN}$ & {$[40]$} \\
\hline Antibacterial & $\begin{array}{l}\text { D. granulosa diphenyl ethers (22, } \\
\text { 23)/sponge }\end{array}$ & Polyketide $^{\mathrm{d}}$ & Gram-positive and negative inhibition & $1-16 \mu \mathrm{g} / \mathrm{mL}^{+}$ & Undetermined & USA & {$[41]$} \\
\hline Antibacterial & diaporthalasin (24)/fungus & Terpenoid $^{\mathrm{e}}$ & MR S. aureus inhibition & $2 \mu \mathrm{g} / \mathrm{mL}^{+}$ & Undetermined & THAI & [42] \\
\hline Antibacterial & D. pulchra furanones $(25,26) /$ alga & Alkaloid $^{\mathrm{f}}$ & P. aeruginosa biofilm inhibition & $1.3 \mu \mathrm{M}^{+}$ & Undetermined & $\begin{array}{l}\text { BRA, FRA, } \\
\text { USA }\end{array}$ & [43] \\
\hline Antibacterial & aureol B (27)/ sponge & Terpenoid $^{\mathrm{e}}$ & Gram-positive and negative inhibition & $1 \mu \mathrm{g} / \mathrm{mL}^{+}$ & Undetermined & S. KOR & [44] \\
\hline Antibacterial & dysidinoid A (28)/sponge & Terpenoid $^{\mathrm{e}}$ & MR S. aureus inhibition & $8 \mu \mathrm{g} / \mathrm{mL}^{* *}$ & Undetermined & $\mathrm{CHN}$ & [45] \\
\hline Antibacterial & Eunicea sp. compounds $(29,30) /$ sponge & Terpenoid $^{\mathrm{e}}$ & $\begin{array}{l}\text { P. aeruginosa and S. aureus biofilm } \\
\text { inhibition }\end{array}$ & $0.5 \mathrm{mg} / \mathrm{mL}^{+}$ & Undetermined & COL & [46] \\
\hline
\end{tabular}


Table 1. Cont.

\begin{tabular}{|c|c|c|c|c|c|c|c|}
\hline Drug Class & Compound/Organism ${ }^{a}$ & Chemistry & Pharmacologic Activity & $\mathrm{IC}_{50} \mathrm{~b}$ & MMOA $^{b}$ & Country $^{c}$ & References \\
\hline Antibacterial & flavipesin A (31)/fungus & Polyketide $^{\mathrm{d}}$ & S. aureus and B. subtillis inhibition & $0.25-8 \mu \mathrm{g} / \mathrm{mL}^{+}$ & Undetermined & $\mathrm{CHN}$ & [47] \\
\hline Antibacterial & gageopeptides A-D (32-35)/bacterium & Peptide $^{f}$ & S. aureus and B. subtillis inhibition & $0.04-0.08 \mu \mathrm{M}^{+}$ & Undetermined & $\begin{array}{l}\text { BGD, S. } \\
\text { KOR }\end{array}$ & [48] \\
\hline Antibacterial & gageotetrins $\mathrm{A}-\mathrm{C}(\mathbf{3 6}-38) /$ bacterium & Peptide $^{\mathrm{f}}$ & S. aureus and B. subtillis inhibition & $0.02-0.04 \mu \mathrm{M}^{+}$ & Undetermined & $\begin{array}{l}\text { BGD, S. } \\
\text { KOR }\end{array}$ & [49] \\
\hline Antibacterial & hormaomycin B (39)/bacterium & Peptide $^{f}$ & S. aureus and K. rhizophila inhibition & $0.4-7 \mu \mathrm{M}^{+}$ & Undetermined & S. KOR & {$[50]$} \\
\hline Antibacterial & ieodoglucomide C (40)/bacterium & Glycolipid & Gram-positive and negative inhibition & $0.01-0.05 \mu \mathrm{M}^{+}$ & Undetermined & S. KOR & {$[51]$} \\
\hline Antibacterial & isoikarugamycin (41)/bacterium & $\begin{array}{l}\text { Alkaloid }{ }^{\mathrm{f}} / \\
\text { Terpenoid }^{\mathrm{e}}\end{array}$ & MR S.aureus & $2-4 \mu \mathrm{g} / \mathrm{mL}^{+}$ & Undetermined & ESP & [52] \\
\hline Antibacterial & keramadine (42)/sponge & Alkaloid $^{\mathrm{f}}$ & M. luteus inhibition & $4 \mu \mathrm{g} / \mathrm{mL}^{+}$ & Undetermined & AUS, JPN & [53] \\
\hline Antibacterial & Ircinia sp. secosterols $(43,44) /$ sponge & Terpenoid $\mathrm{e}$ & M. luteus and S. epidermidis inhibition & $3.1,6.3 \mu \mathrm{g} / \mathrm{mL}$ & Undetermined & S. KOR & {$[54,55]$} \\
\hline Antibacterial & L. dendyi terpenoids $(45,46) /$ sponge & Polyketide $^{\mathrm{d}}$ & MR S. aureus inhibition & $0.05-0.29 \mu \mathrm{M}$ & Undetermined & USA & {$[56]$} \\
\hline Antibacterial & lindgomycin $(47) /$ fungus & Polyketide $^{\mathrm{d}}$ & MR S. aureus inhibition & $5.1 \mu \mathrm{M}$ & Undetermined & CHN, DEU & {$[57]$} \\
\hline Antibacterial & marformysin $\mathrm{D}(48) /$ bacterium & Peptide $^{\mathrm{f}}$ & M. luteus inhibition & $0.063 \mu \mathrm{g} / \mathrm{mL}^{+}$ & Undetermined & $\mathrm{CHN}$ & [58] \\
\hline Antibacterial & mollemycin A (49)/bacterium & Polyketide $^{\mathrm{d}}$ & S. aureus and S. epidermidis inhibition & $0.05 \mu \mathrm{M}$ & Undetermined & AUS & [59] \\
\hline Antibacterial & neolaurene (50)/alga & Terpenoid ${ }^{\mathrm{e}}$ & S. typhi and S. aureus inhibition & $7.5 \mu \mathrm{g} / \mathrm{mL}$ & Undetermined & MYS & [60] \\
\hline Antibacterial & penicyclone $\mathrm{A}(51) /$ fungus & Polyketide $^{\mathrm{d}}$ & S. aureus inhibition & $0.3 \mu \mathrm{g} / \mathrm{mL}^{+}$ & Undetermined & $\mathrm{CHN}$ & [61] \\
\hline Antibacterial & P. oxalicum enamide (52)/fungus & Polyketide ${ }^{\mathrm{d}}$ & S. aureus inhibition & $2 \mu \mathrm{g} / \mathrm{mL}^{+}$ & Undetermined & $\mathrm{CHN}$ & [62] \\
\hline Antibacterial & puupehenol (53)/ sponge & Terpenoid ${ }^{\mathrm{e}}$ & B. cereus and S. aureus inhibition & $10 \mu \mathrm{g} / \mathrm{disk}^{+}$ & Undetermined & AUS, USA & [63] \\
\hline Antibacterial & phyllospongin E (54)/sponge & Terpenoid e & B. cereus and S. aureus inhibition & $2.5-3.3 \mu \mathrm{g} / \mathrm{mL}^{+}$ & Undetermined & EGY, GBR & [64] \\
\hline Antibacterial & sarcotrocheliols $(55,56) /$ soft coral & Terpenoid ${ }^{\mathrm{e}}$ & MR S. aureus inhibition & $1.5-4.3 \mu \mathrm{M}^{+}$ & Undetermined & SAU & [65] \\
\hline Antibacterial & spiromastixone J (57)/fungus & Polyketide $^{\mathrm{d}}$ & MR S. aureus inhibition & $2 \mu \mathrm{M}$ & Undetermined & CHN, DEU & {$[66]$} \\
\hline Antibacterial & stachyin B (58)/fungus & $\begin{array}{l}\text { Alkaloid }{ }^{\mathrm{f}} \\
\text { /Terpenoid }^{\mathrm{e}}\end{array}$ & MR S. aureus and B. subtillis inhibition & $1.4-1.7 \mu \mathrm{M}$ & Undetermined & $\mathrm{CHN}, \mathrm{DEU}$ & {$[67]$} \\
\hline Antibacterial & $\begin{array}{l}\text { Streptomyces sp. glycoside } \\
\text { (59)/bacterium }\end{array}$ & Polyketide $^{\mathrm{d}}$ & C. trachomatis inhibition & $4.03 \mu \mathrm{M}$ & Undetermined & EGY, DEU & {$[68]$} \\
\hline Antibacterial & $\begin{array}{l}\text { subergosterones A-C } \\
(\mathbf{6 0 - 6 2 ) / g o r g o n i a n ~ c o r a l ~}\end{array}$ & Terpenoid ${ }^{\mathrm{e}}$ & B. cereus inhibition & $1.6-3.1 \mu \mathrm{M}^{+}$ & Undetermined & $\mathrm{CHN}$ & [69] \\
\hline Antibacterial & vitroprocine A (63)/bacterium & Polyketide $^{\mathrm{d}}$ & A. baumannii inhibition & $8 \mu \mathrm{g} / \mathrm{mL}^{+}$ & Undetermined & TWN, USA & {$[70]$} \\
\hline Antibacterial & xestospongiamide $(64) /$ sponge & Polyketide $^{\mathrm{d}}$ & Gram-positive and negative inhibition & $2.5 \mu \mathrm{M}^{+}$ & Undetermined & EGY, SAU & {$[71]$} \\
\hline Antifungal & bahamaolide A (65)/bacterium & Polyketide $^{\mathrm{d}}$ & C. albicans inhibition & $1.5-3.1 \mu \mathrm{g} / \mathrm{mL}^{+}$ & ICL inhibition & S. KOR & {$[72]$} \\
\hline Antifungal & heronamide C (66)/bacterium & $\begin{array}{l}\text { Polyketal/ } \\
\text { alkaloid }^{\mathrm{f}}\end{array}$ & S. pombe cell inhibition & $5.8 \mu \mathrm{M}^{+}$ & $\begin{array}{l}\text { Alteration of } \\
\text { membrane } \\
\text { microdomains }\end{array}$ & JPN & [73] \\
\hline Antifungal & forazoline A (67)/bacterium & Polyketide $^{\mathrm{d}}$ & C. albicans inhibition & $16 \mu \mathrm{g} / \mathrm{mL}^{+}$ & $\begin{array}{l}\text { Affected membrane } \\
\text { integrity }\end{array}$ & USA & [74] \\
\hline Antifungal & aaptamine derivative (68)/sponge & Alkaloid $^{\mathrm{f}}$ & T. rubrum inhibition & $4 \mu \mathrm{g} / \mathrm{mL}^{+}$ & Undetermined & $\mathrm{CHN}$ & [75] \\
\hline
\end{tabular}


Table 1. Cont.

\begin{tabular}{|c|c|c|c|c|c|c|c|}
\hline Drug Class & Compound/Organism $^{a}$ & Chemistry & Pharmacologic Activity & $\mathrm{IC}_{50} \mathrm{~b}$ & MMOA $^{b}$ & Country $^{c}$ & References \\
\hline Antifungal & amphidinin G (69)/dinoflagellate & Polyketide $^{\mathrm{d}}$ & T. mentagrophytes inhibition & $8 \mu \mathrm{g} / \mathrm{mL}$ & Undetermined & JPN & [76] \\
\hline Antifungal & amphidinol 18 (70)/dinoflagellate & Polyketide $^{\mathrm{d}}$ & C. albicans inhibition & $9 \mu \mathrm{g} / \mathrm{mL}^{+}$ & Undetermined & ITA & [77] \\
\hline Antifungal & $\begin{array}{l}\text { crambescin homologues } \\
(71-73) / \text { sponge }\end{array}$ & Alkaloid $^{\mathrm{f}}$ & C. neoformans var. gattii inhibition & $0.85-2.6 \mu \mathrm{M}^{+}$ & Undetermined & USA & [78] \\
\hline Antifungal & $\begin{array}{l}\text { coustesides } \mathrm{C} \text { and } \mathrm{D}(\mathbf{7 4}, \mathbf{7 5}) / \mathrm{sea} \\
\text { cucumber }\end{array}$ & $\begin{array}{l}\text { Terpenoid } \\
\text { glycoside }^{\mathrm{e}}\end{array}$ & C. albicans inhibition & $1 \mathrm{mg} / \mathrm{mL}^{++}$ & Undetermined & $\begin{array}{l}\text { EGY, } \\
\text { S.KOR }\end{array}$ & [79] \\
\hline Antifungal & L. okamurai laurenes (76-78)/alga & Terpenoid ${ }^{\mathrm{e}}$ & C. glabrata inhibition & $2-4 \mu \mathrm{g} / \mathrm{mL}^{* *}$ & Undetermined & $\mathrm{CHN}$ & {$[80,81]$} \\
\hline Antifungal & mohangamide A (79)/bacterium & Peptide $^{\mathrm{f}}$ & C. albicans isocitrate lyase inhibition & $4.4 \mu \mathrm{M}$ & Undetermined & S. KOR & {$[82]$} \\
\hline Antifungal & pleosporallin E (80)/fungus & Polyketide $^{\mathrm{d}}$ & C. albicans inhibition & $7.44 \mu \mathrm{g} / \mathrm{mL}^{+}$ & Undetermined & $\mathrm{CHN}$ & [83] \\
\hline Antifungal & $\begin{array}{l}\text { S. purpurea lysophospholipid } \\
\text { (81)/sponge }\end{array}$ & Phospholipid & C. glabrata and C. neoformans inhibition & $4 \mu \mathrm{g} / \mathrm{mL}^{+}$ & Undetermined & $\mathrm{CHN}$ & [84] \\
\hline Antifungal & taurospongin A (82)/sponge & Polyketide $^{\mathrm{d}}$ & C. neoformans inhibition & $1 \mu \mathrm{g} / \mathrm{mL}^{+}$ & Undetermined & AUS, JPN & [85] \\
\hline Antifungal & variegatuside $\mathrm{D}(83) /$ sea cucumber & $\begin{array}{l}\text { Terpenoid } \\
\text { glycoside }^{\mathrm{e}}\end{array}$ & Several Candida species inhibition & $3.4-13.6 \mu \mathrm{g} / \mathrm{mL}^{+}$ & Undetermined & $\mathrm{CHN}$ & {$[86]$} \\
\hline Antifungal & xestospongiamide (64)/sponge & Polyketide ${ }^{\mathrm{d}}$ & A. niger and C. albicans inhibition & $>5 \mu \mathrm{M}^{+}$ & Undetermined & EGY, SAU & [71] \\
\hline Antimalarial & C. hooperi isonitrile (84)/sponge & Terpenoid ${ }^{\mathrm{e}}$ & $\begin{array}{l}\text { P. falciparum D6 and W2 strain } \\
\text { inhibition }\end{array}$ & $4.3-4.7 \mathrm{nM}$ & $\beta$-hematin inhibition & USA, ZAF & {$[87]$} \\
\hline Antimalarial & actinoramide A (85)/bacterium & Peptide ${ }^{f}$ & P. falciparum strains inhibition & $0.2 \mu \mathrm{M}$ & Undetermined & CRI, USA & {$[88]$} \\
\hline Antimalarial & diacarperoxide J (86)/sponge & Terpenoid ${ }^{\mathrm{e}}$ & $\begin{array}{l}\text { P. falciparum D6 and W2 strain } \\
\text { inhibition }\end{array}$ & $1.6-1.8 \mu \mathrm{M}$ & Undetermined & CHN, USA & [89] \\
\hline Antimalarial & laevigatol A (87)/soft coral & Terpenoid $^{\mathrm{e}}$ & P. falciparum NF54 strain inhibition & $3.0 \mu \mathrm{M}$ & Undetermined & $\begin{array}{l}\text { CHE, DEU, } \\
\text { S. KOR, } \\
\text { VNM }\end{array}$ & [90] \\
\hline Antimalarial & mollemycin A (49)/bacterium & Polyketide $^{\mathrm{d}}$ & $\begin{array}{l}\text { P. falciparum 3D7and Dd2 strain } \\
\text { inhibition }\end{array}$ & $7-9 \mathrm{nM}$ & Undetermined & AUS & [59] \\
\hline Antimalarial & $\begin{array}{l}\text { mon amphilectines B and C (88, } \\
\text { 89)/sponge }\end{array}$ & Terpenoid ${ }^{\mathrm{e}}$ & P. falciparum 3D7strain inhibition & $44 \mathrm{nM}$ & Undetermined & USA & [91] \\
\hline Antimalarial & netamine $\mathrm{K}(\mathbf{9 0}) /$ sponge & Alkaloid $^{\mathrm{f}}$ & P. falciparum inhibition & $2.4 \mu \mathrm{M}$ & Undetermined & $\begin{array}{l}\text { BEL, FRA, } \\
\text { ISR }\end{array}$ & [92] \\
\hline Antimalarial & 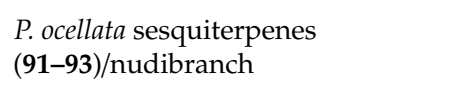 & Terpenoid ${ }^{\mathrm{e}}$ & P. falciparum inhibition & $0.26-0.3 \mu \mathrm{M}$ & Undetermined & AUS, ITA & [93] \\
\hline Antimalarial & P. simplex polyketide (94)/sponge & Polyketide $^{\mathrm{d}}$ & $\begin{array}{l}\text { P. falciparum D10 and W2 strain } \\
\text { inhibition }\end{array}$ & $2.7-4.0 \mu \mathrm{M}$ & Undetermined & CHN, ITA & [94] \\
\hline Antiprotozoal & plakortide E (95)/sponge & Polyketide $^{\mathrm{d}}$ & T. brucei inhibition & $5 \mu \mathrm{M}$ & Rhodesain inhibition & EGY, DEU & [95] \\
\hline Antiprotozoal & batzelladine L (96)/sponge & Alkaloid ${ }^{\mathrm{f}}$ & T. cruzi and L. infantum inhibition & $2 \mu \mathrm{M}$ & $\begin{array}{l}\text { Enhanced ROS } \\
\text { generation }\end{array}$ & BRA, CAN & [96] \\
\hline
\end{tabular}


Table 1. Cont

\begin{tabular}{|c|c|c|c|c|c|c|c|}
\hline Drug Class & Compound/Organism ${ }^{a}$ & Chemistry & Pharmacologic Activity & $\mathrm{IC}_{50} \mathrm{~b}$ & MMOA $^{b}$ & Country $^{c}$ & References \\
\hline Antiprotozoal & actinoporin A (97)/ bacterium & Polyketide $^{\mathrm{d}}$ & T. b. brucei inhibition & $15 \mu \mathrm{M}$ & Undetermined & $\begin{array}{l}\text { AUS, DEU, } \\
\text { EGY, GBR } \\
\text { DEU, }\end{array}$ & [97] \\
\hline Antiprotozoal & astropectenol A (98)/soft coral & Terpenoid ${ }^{\mathrm{e}}$ & T. brucei inhibition & $1.6 \mu \mathrm{M}$ & Undetermined & $\begin{array}{l}\text { VNM, S. } \\
\text { KOR }\end{array}$ & {$[98]$} \\
\hline Antiprotozoal & H. simulans sterol (99) sponge & Terpenoid ${ }^{\mathrm{e}}$ & T. b. brucei inhibition & $4.6 \mu \mathrm{M}^{+}$ & Undetermined & IRL, GBR & [99] \\
\hline Antiprotozoal & lobosamide A (100)/bacterium & Alkaloid $^{\mathrm{f}}$ & T. b. brucei inhibition & $0.8 \mu \mathrm{M}$ & Undetermined & USA & [100] \\
\hline Antiprotozoal & $\begin{array}{l}\text { lobocrasols } A \text { and } C(\mathbf{1 0 1}, \mathbf{1 0 2}) / \text { soft } \\
\text { corals }\end{array}$ & Terpenoid ${ }^{\mathrm{e}}$ & L. donovani inhibition & $0.18 \mu \mathrm{M}$ & Undetermined & $\begin{array}{l}\text { CHE, DEU, } \\
\text { S. KOR, } \\
\text { VNM }\end{array}$ & {$[90]$} \\
\hline Antiprotozoal & mangromicin A (103)/fungus & Polyketide $^{\mathrm{d}}$ & T. $b$. brucei inhibition & $2.44 \mu \mathrm{g} / \mathrm{mL}$ & Undetermined & JPN & {$[101]$} \\
\hline Antiprotozoal & $\begin{array}{l}\text { crassumols D and E }(\mathbf{1 0 4}, \mathbf{1 0 5}) / \text { soft } \\
\text { corals }\end{array}$ & Terpenoid ${ }^{\mathrm{e}}$ & T. $b$. rhodesiense inhibition & 0.61 and $0.72 \mu \mathrm{M}$ & Undetermined & $\begin{array}{l}\text { CHE, DEU, } \\
\text { S. KOR, } \\
\text { VNM }\end{array}$ & {$[90]$} \\
\hline Antiprotozoal & sesterstamide (106)/sponge & Terpenoid ${ }^{\mathrm{e}}$ & L. donovani inhibition & $32.9 \mu \mathrm{g} / \mathrm{mL}$ & Undetermined & $\mathrm{CHN}$ & [102] \\
\hline Antiprotozoal & shagene A (107)/soft coral & Terpenoid ${ }^{\mathrm{e}}$ & L. donovani inhibition & $5 \mu \mathrm{M}$ & Undetermined & AUS, USA & [103] \\
\hline Antituberculosis & aaptamine analog (108)/sponge & Alkaloid $^{\mathrm{f}}$ & M. smegmatis inhibition & $6.25 \mu \mathrm{g} / \mathrm{mL}^{+}$ & Undetermined & JPN & {$[104]$} \\
\hline Antituberculosis & callyaerins $\mathrm{A}$ and $\mathrm{B}(\mathbf{1 0 9}, \mathbf{1 1 0}) /$ sponge & Peptide $^{\mathrm{f}}$ & M. tuberculosis inhibition & $2,5 \mu \mathrm{M}^{* *}$ & Undetermined & $\begin{array}{l}\text { CHN, DEU, } \\
\text { NLD }\end{array}$ & {$[105]$} \\
\hline Antituberculosis & denigrin C (111)/sponge & Alkaloid $^{\mathrm{f}}$ & M. tuberculosis $\mathrm{H}_{37} \mathrm{Rv}$ inhibition & $4 \mu \mathrm{g} / \mathrm{mL}^{+}$ & Undetermined & IND & {$[106]$} \\
\hline Antituberculosis & oxazinin A (112)/fungus & Polyketide $^{\mathrm{d}}$ & M. tuberculosis inhibition & $2.9 \mu \mathrm{M}$ & Undetermined & USA & [107] \\
\hline Antiviral & pateamine A (113)/sponge & $\begin{array}{l}\text { Mixed } \\
\text { Biogenesis }\end{array}$ & $\begin{array}{l}\text { Sindbis virus mRNA translation } \\
\text { inhibition }\end{array}$ & $>100 \mathrm{nM}$ & $\begin{array}{l}\mathrm{nsP} 1 \text { or nsP2 viral } \\
\text { protein synthesis } \\
\text { inhibition }\end{array}$ & $\begin{array}{l}\text { CAN, ESP, } \\
\text { NZL }\end{array}$ & [108] \\
\hline Antiviral & abyssomicin 2 (114)/bacterium & Polyketide $^{\mathrm{d}}$ & HIV-1 reactivation & $13.9 \mu \mathrm{M}$ & $\begin{array}{l}\text { Increased viral RNA } \\
\text { in CD4 }{ }^{+} \mathrm{T} \text { cells } \\
\text { Reverse }\end{array}$ & USA & [109] \\
\hline Antiviral & 8,4'"-dieckol (115)/alga & Polyketide $^{\mathrm{d}}$ & HIV-1 inhibition & $10 \mu \mathrm{M} *$ & $\begin{array}{l}\text { transcriptase } \\
\text { inhibition }\end{array}$ & S. KOR & {$[110]$} \\
\hline Antiviral & truncateol M (116)/fungus & Terpenoid ${ }^{\mathrm{e}}$ & H1N1 influenza A virus inhibition & $8.8 \mu \mathrm{M}$ & $\begin{array}{l}\text { Virion } \\
\text { assembly/release } \\
\text { inhibition }\end{array}$ & CHN, DEU & [111] \\
\hline Antiviral & neoechinulin B (117)/fungus & Alkaloid $^{\mathrm{f}}$ & $\begin{array}{l}\text { H3N2, H1N1 A influenza virus } \\
\text { inhibition }\end{array}$ & $17-22 \mu \mathrm{M}$ & $\begin{array}{l}\text { Hemagglutinin } \\
\text { inhibition }\end{array}$ & CHN, DEU & {$[112]$} \\
\hline Antiviral & thaixylomolin I (118)/mangrove & Terpenoid ${ }^{\mathrm{e}}$ & H1N1 influenza A virus inhibition & $77 \mu \mathrm{M}$ & Undetermined & $\begin{array}{l}\text { CHN, DEU, } \\
\text { THAI }\end{array}$ & {$[113]$} \\
\hline
\end{tabular}


Table 1. Cont.

\begin{tabular}{|c|c|c|c|c|c|c|c|}
\hline Drug Class & Compound/Organism $^{\text {a }}$ & Chemistry & Pharmacologic Activity & $\mathrm{IC}_{50} \mathrm{~b}$ & MMOA $^{b}$ & Country $^{c}$ & References \\
\hline Antiviral & aaptamine derivative (68)/sponge & Alkaloid $^{\mathrm{f}}$ & HIV-1 inhibition & $10 \mu \mathrm{M}^{*}$ & Undetermined & $\mathrm{CHN}$ & [75] \\
\hline Antiviral & aflaquinolone B derivative (119)/fungus & $\begin{array}{l}\text { Mixed } \\
\text { biogenesis }\end{array}$ & RSV inhibition & $0.042 \mu \mathrm{M}$ & Undetermined & $\mathrm{CHN}$ & [114] \\
\hline Antiviral & A. terreus lactones $(\mathbf{1 2 0}, \mathbf{1 2 1}) /$ fungus & $\begin{array}{l}\text { Polyketide } \\
\text { Alkaloid }\end{array}$ & HSV-1 inhibition & $6.34 \mu \mathrm{g} / \mathrm{mL}$ & Undetermined & $\mathrm{CHN}$ & [115] \\
\hline Antiviral & chartarutine B (122)/fungus & $\mathrm{e}_{\mathrm{e}}^{\mathrm{f}}$ terpenoid & HIV-1 inhibition & $4.9 \mu \mathrm{M}$ & Undetermined & $\mathrm{CHN}, \mathrm{DEU}$ & [116] \\
\hline Antiviral & $\begin{array}{l}\text { debromoaplysiatoxin } \\
\text { (123)/cyanobacterium }\end{array}$ & Polyketide $^{\mathrm{d}}$ & CHIKV inhibition & $1.4 \mu \mathrm{M}$ & Undetermined & NZL, SGP & [117] \\
\hline Antiviral & dolabelladienol A (124)/alga & Terpenoid $^{\text {e }}$ & HIV-1 inhibition & $2.9 \mu \mathrm{M}$ & Undetermined & $\begin{array}{l}\text { BRA, COL, } \\
\text { ESP }\end{array}$ & [118] \\
\hline Antiviral & D. plectens diterpene (125)/alga & Terpenoid $^{\mathrm{e}}$ & HIV-1 inhibition & $16.1 \mu \mathrm{M}$ & Undetermined & $\mathrm{CHN}$ & [119] \\
\hline Antiviral & Dysidea sp. PBDEs $(\mathbf{2 2}, \mathbf{2 3}) /$ sponge & Polyketide $^{\mathrm{d}}$ & Hepatitis B inhibition & $0.23-0.80 \mu \mathrm{M}$ & $\begin{array}{l}\text { Core promoter } \\
\text { inhibition }\end{array}$ & $\begin{array}{l}\text { IDN, JPN, } \\
\text { NLD }\end{array}$ & [120] \\
\hline Antiviral & echrebsteroid C (126)/gorgonian & Terpenoid ${ }^{\text {e }}$ & RSV inhibition & $0.19 \mu \mathrm{M}$ & Undetermined & $\mathrm{CHN}$ & [121] \\
\hline Antiviral & (+)-pestaloxazine $\mathrm{A}(\mathbf{1 2 7}) /$ fungus & Alkaloid $^{\mathrm{f}}$ & Enterovirus 71 inhibition & $14.2 \mu \mathrm{M}$ & Undetermined & $\mathrm{CHN}$ & [122] \\
\hline Antiviral & phlorofucofuroeckol-A(10)/alga & Polyketide ${ }^{d}$ & MNV inhibition & $0.9 \mu \mathrm{M}$ & Undetermined & S. KOR & {$[123]$} \\
\hline Antiviral & secocrassumol (128)/soft coral & Terpenoid $\mathrm{e}$ & HCMV inhibition & $5 \mu \mathrm{g} / \mathrm{mL}$ & Undetermined & TWN & [124] \\
\hline Antiviral & sporolide B (129)/bacterium & Polyketide $^{\mathrm{d}}$ & HIV-reverse transcriptase inhibition & $14 \mu \mathrm{M}$ & Undetermined & IND & [125] \\
\hline Antiviral & $\begin{array}{l}\text { stellettapeptins A and B (130, } \\
\text { 131)/sponge }\end{array}$ & Peptide $^{f}$ & HIV-1 infection inhibition & $23-27 \mathrm{nM}$ & Undetermined & USA & [126] \\
\hline Antiviral & trichobotrysin $\mathrm{A}(\mathbf{1 3 2}) /$ fungus & $\begin{array}{l}\text { Polyketide }{ }^{\mathrm{d}} \\
\text { /Alkaloid }^{\mathrm{f}}\end{array}$ & HSV-1 inhibition & $3.08 \mu \mathrm{M}$ & Undetermined & $\mathrm{CHN}$ & [127] \\
\hline Anthelmintic & phorioadenine A (133)/sponge & Alkaloid ${ }^{\mathrm{f}}$ & H. contortus inhibition & $31 \mu \mathrm{g} / \mathrm{mL}^{+++}$ & Undetermined & AUS & [128] \\
\hline
\end{tabular}

a Organism: Kingdom Animalia: ascidian, flatfish, sea snakes (Phylum Chordata), gorgonian, coral (Phylum Cnidaria), sea cucumber (Phylum Echinodermata), nudibranch (Phylum Mollusca), sponge (Phylum Porifera); Kingdom Monera: bacterium (Phylum Cyanobacteria); Kingdom Fungi: fungus; Kingdom Plantae: alga, mangrove, seagrass; Kingdom Protista: dinoflagellates; ${ }^{b}$ IC $_{50}$ : concentration of a compound required for $50 \%$ inhibition in vitro, ${ }^{*}$ : estimated IC $\mathrm{IC}_{50}, * *$ : MIC $\mathrm{M}_{80}$, MIC $\mathrm{M}_{90}$, or IC $\mathrm{IC}_{90}$, ***: in vivo study; ${ }^{+}$MIC: minimum inhibitory concentration, ${ }^{++}$MID: minimum inhibitory concentration per disk; ${ }^{+++}$LC $_{90}$ : concentration of a compound required for $90 \%$ lethality; ${ }^{b}$ MMOA: molecular mechanism of action c Country: AUS: Australia; BEL: Belgium; BGD: Bangladesh; BRA: Brazil; CAN: Canada; CHE: Switzerland; CHN: China; COL: Colombia; CRI: Costa Rica; DEU: Germany; EGY: Egypt; ESP: Spain; FRA: France; GBR: United Kingdom; IDN: Indonesia; IND: India; IRL: Ireland; ISR: Israel; ITA: Italy; JPN: Japan; MYS: Malaysia; NLD: The Netherlands; NZL: New Zealand; PRT: Portugal; SAU: Saudi Arabia; SGP: Singapore; S. KOR: South Korea; THAI: Thailand; TWN: Taiwan; VNM: Vietnam; ZAF: S. Africa; Chemistry: ${ }^{\mathrm{d}}$ polyketide; ${ }^{\mathrm{e}}$ terpene; ${ }^{f}$ nitrogen-containing compound; ${ }^{g}$ polysaccharide; ${ }^{\text {h }}$ shikimate; Abbreviations: CHIKV: chikungunya virus; HCMV: human cytomegalovirus; MNV: murine norovirus; HSV: herpes simplex virus; ICL: isocitrate lyase; MR: methicillin-resistant; PBP2a: penicillin-binding protein 2a; RNAP: RNA-polymerase; RSV: respiratory syncytial virus; TNF- $\alpha$ : tumor necrosis factor $\alpha$. 


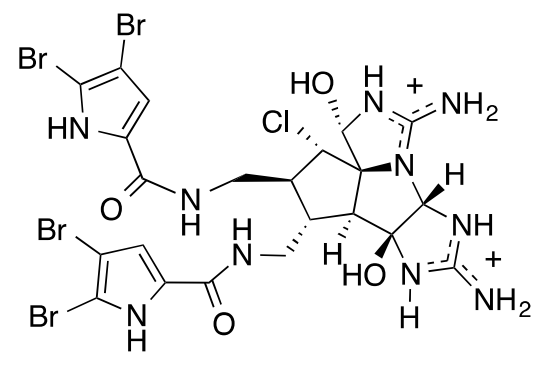

axinellamine $\mathrm{A}(\mathbf{1})$

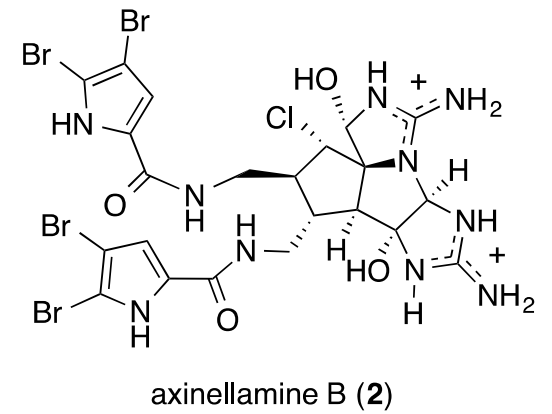

axinellamine B (2)<smiles>C[C@](CO)(NC=O)C(=O)O</smiles><smiles>COc1ccc2oc3c(O)c4c(c(O)c3c(=O)c2c1O)-c1c(cc(CC(C)=O)c(C(N)=O)c1O)CC4</smiles>

buanmycin (3)<smiles>COc1c(Br)cc(/C=C/C(=O)NCCCNCCCCN)cc1Br</smiles><smiles>CC#CC[C@H](C)C1=CC[C@H]2[C@@H]3C(O)C=C4C[C@@H](O)CC[C@]4(C)C3CC[C@]12C</smiles>

gelliusterol E (6)
GFFALIPKIISSPLFKTLLSAVGSALSSSGGQE

pardaxin (9)

H-FIHHIIGGLFSAGKAIHRLIRRRRR-OH TP4 (13)<smiles>COc1c(Br)cc(/C=C/C(=O)NCCCNCCCCNCCCNC(=O)/C=C/c2cc(Br)c(OC)c(Br)c2)cc1Br</smiles>

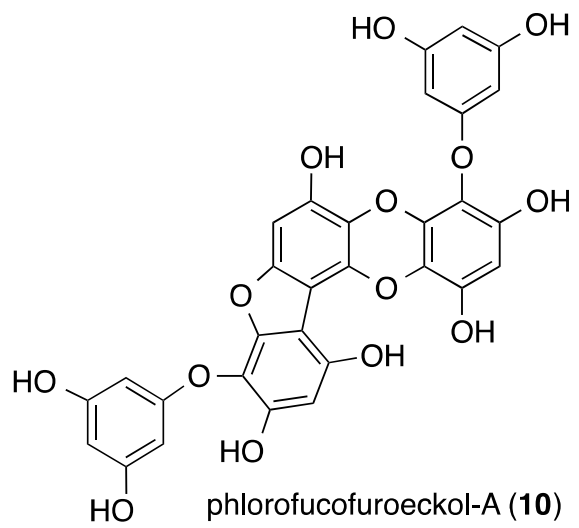

H-FIHHIIGGLFSVGKHIHSLIHGH-OH TP3 (12)

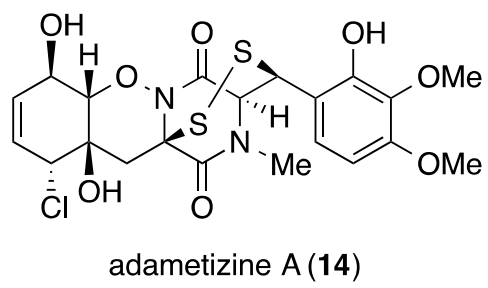

Figure 1. Cont. 


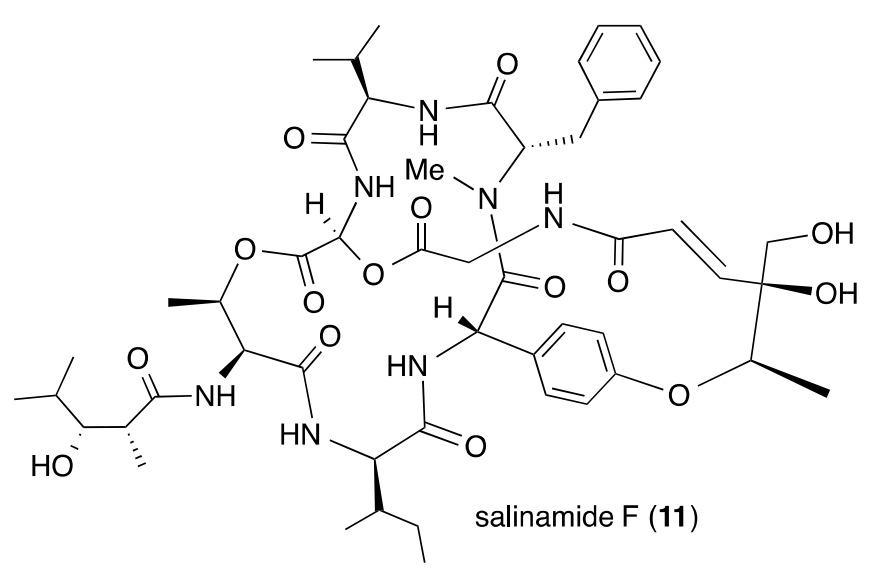<smiles>COC1=C(c2ccc(O)cc2)[C@@](C)(Cc2ccc(O)c(CC=C(C)C)c2)OC1=O</smiles>

2-O-methylbutyrolactone I (17)

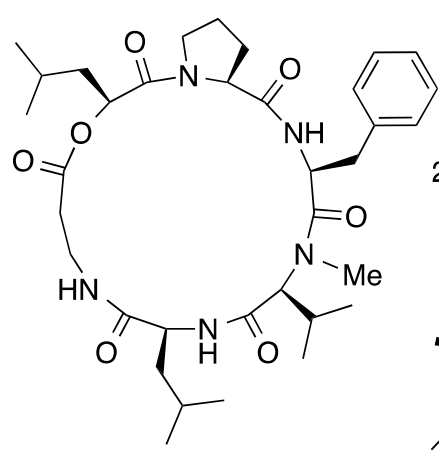

desmethylisaridin $\mathrm{C} 1$ (21)<smiles>Oc1cc(Br)c(Br)c(Br)c1Oc1ccc(Br)cc1Br</smiles>

2-(2',4'-dibromophenoxy)-3,4,5-tribromophenol (23)

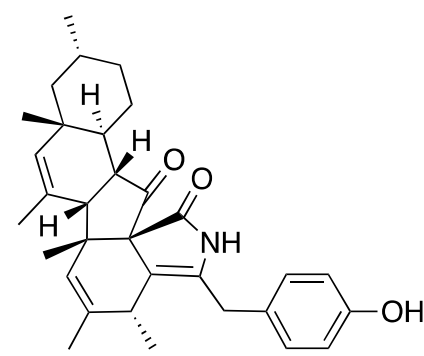
diaporthalasin (24)

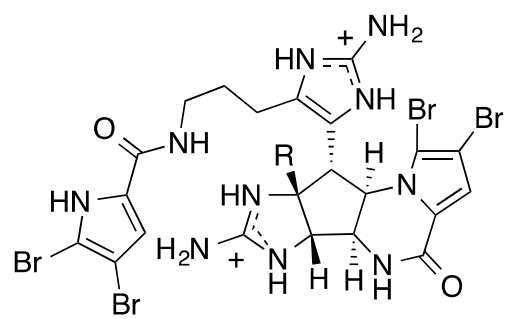

agelamadin $A(15) R=O M e$ agelamadin $B$ (16) $R=O H$

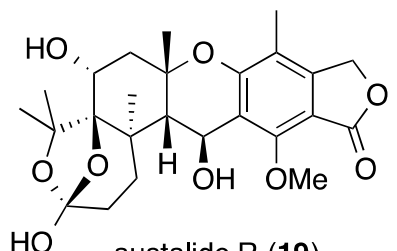

$\mathrm{HO}$ austalide R (19)<smiles>COc1cc(C2CC3O[C@H](C)[C@H](C)c4c(cc(O)c(C)c43)O2)ccc1O</smiles>
2-(2',4'-dibromophenoxy)-3,5-dibromophenol (22)<smiles>COc1ccc(C)cc1C1=C(Br)C(=O)N(CC(C)C)/C1=C\c1cccc(Cl)c1</smiles>

(Z)- $\gamma$-alkylidene- $\gamma$-lactam 25<smiles>COc1ccc(Cl)cc1C1=C(Br)C(=O)N(CC(C)C)/C1=C\c1ccccc1Br</smiles>

(Z)- $\gamma$-alkylidene- $\gamma$-lactam 26

Figure 1. Cont. 


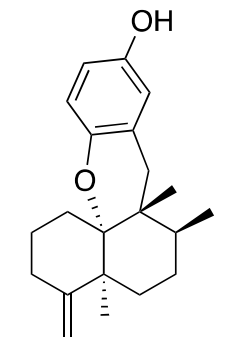

aureol B (27)

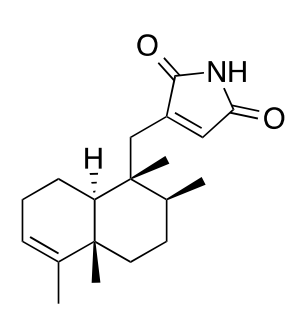

dysidinoid $\mathrm{A}$ (28)

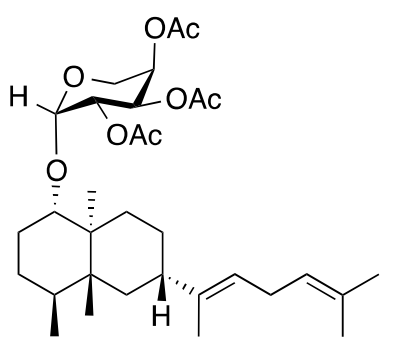

fuscoside E peracetate (29)<smiles>CCCCCCCCCCCCCCCCCCOC[C@H](O)CO</smiles><smiles>CCC(C)C(C)(C)CC(=O)NCC(=O)NC(CCC(=O)O)C(=O)NC(CC(C)C)C(=O)NC(CC(C)C)C(=O)O</smiles>

gageopeptide $A$ (32)<smiles>CCCCOC(=O)C1(Cc2ccccc2)C=C(O)C(=O)O1</smiles>

flavipesin A (31)<smiles>CCC(C)C(C)(C)C(C)(O)CC(=O)N[C@@H](CCOC(C)=O)C(=O)NC(CC(C)C)C(=O)NCC(=O)NC(CC(C)C)C(=O)NC(CC(C)C)C(=O)O</smiles><smiles></smiles>

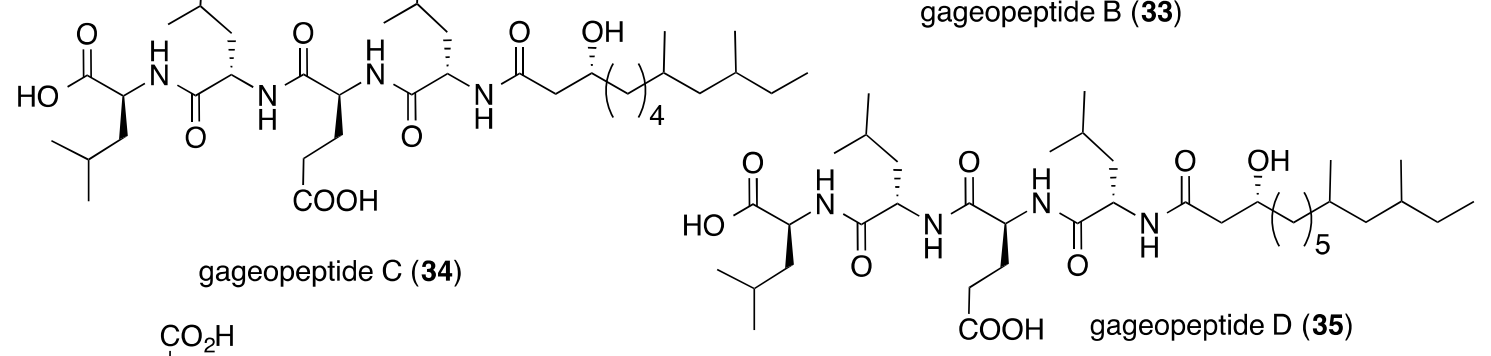<smiles>CCC(C)(C)C(C)(C)CC(=O)N[C@@H](CCC(C)=O)C(=O)NC(CC(C)C)C(=O)NC(CC(C)C)C(=O)N[C@@H](CC(C)C)C(=O)O</smiles><smiles>CCC(C)CC(C)(C)C(C)(C)CC(=O)N[C@@H](CCC(=O)O)C(=O)NC(CC(C)C)C(=O)N[C@@H](CC(C)C)C(=O)NC(CC(C)C)C(=O)O</smiles>

Figure 1. Cont. 

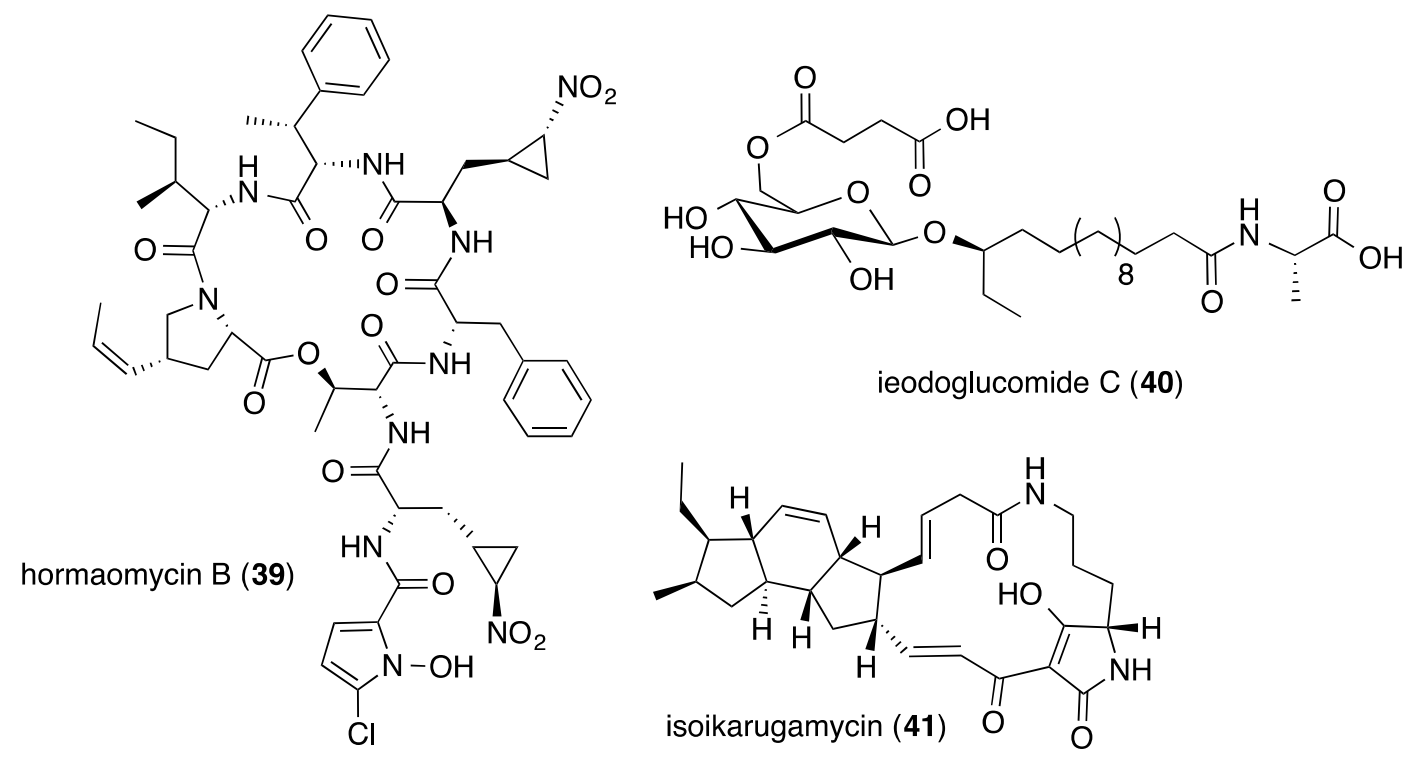

ieodoglucomide C (40)<smiles>C[14C](=O)[14CH2]c1c[nH][n+](N)c1/C=C\CNC(=O)c1cc(Br)c[nH]1</smiles>

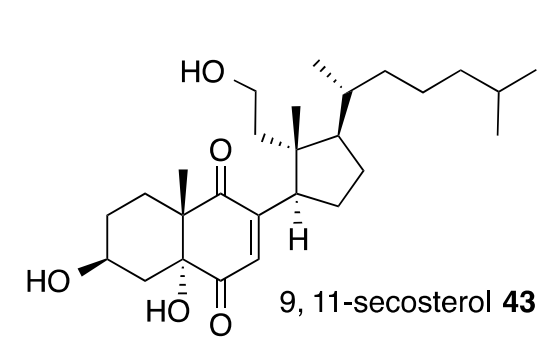<smiles>Oc1c(Br)cc(Br)cc1Oc1c(O)c(Br)c(Br)c(Br)c1Br</smiles>

45<smiles>CC(C)C(C)/C=C\[C@H](C)C1CC[C@H](C2=CC(=O)[C@@]3(O)C[C@@H](O)CC[C@]3(C)C2=O)[C@]1(C)CCO</smiles>

9, 11-secosterol 44

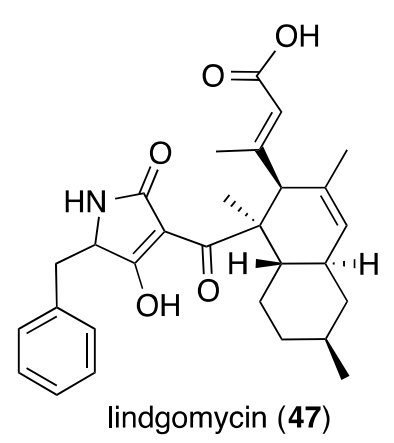<smiles>CC[C@H](C)CCN1NCCC[C@H]1CN</smiles>
penicyclone $\mathrm{A}$ (51)<smiles>CC1=CC(=O)[C@]2(CC[C@@H](C)C(=O)O2)[C@H](O)[C@@H]1O</smiles><smiles>COC(=O)/C(=C/c1ccc(O)c(O)c1)NC=O</smiles>
enamide 52<smiles>Oc1c(Br)cc(Br)cc1Oc1cc(Br)c(Br)c(Br)c1O</smiles><smiles>CC1=CC[C@](C)(c2ccc(C)cc2)[C@H]1C</smiles>
neolaurene (50)

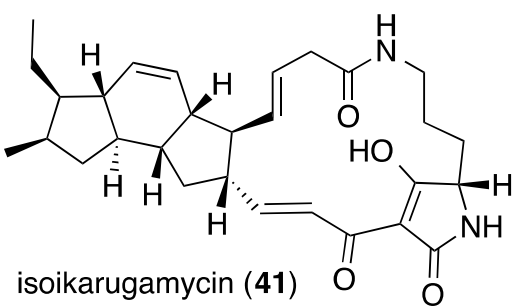

HO 9 9, 11-secosterol 43 


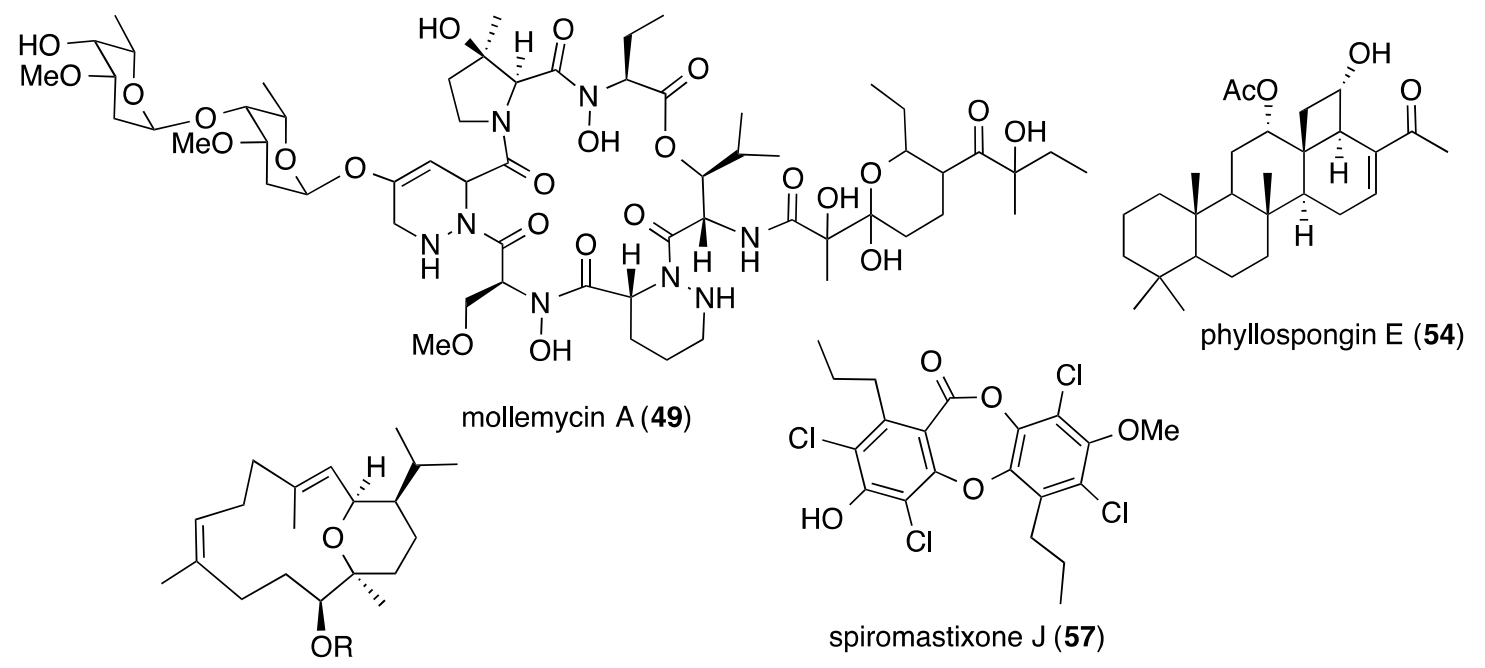

sarcotrocheliol acetate (55) $\mathrm{R}=\mathrm{Ac}$ sarcotrocheliol (56) $\mathrm{R}=\mathrm{H}$

$\mathrm{HO}$<smiles>CC1CCC2C(C)(C)CCCC2(C)C12CC2</smiles><smiles>CC1CCC2C(CCC(O)C2(C)C)C12Cc1c(O)cc3c(c1O2)COC3</smiles><smiles>O=C1c2cc(O)c3c(c2CCO3)OC1C1OCc2cc(O)c3c(c21)OCC3</smiles>
stachyin B (58)<smiles>CCCCCCCCCCC1CCCC1C1CCC2CC(=O)C=CC21C</smiles><smiles>CC(C)C/C=C\C(C)[C@H]1CC[C@H]2[C@@H]3CC[C@H]4CC(=O)C=C[C@]4(C)[C@H]3CC[C@]21C</smiles><smiles>COC(=O)c1c(C)cc2c(c1O)[C@]1(O)C(=O)c3cc4c(c(O)c3C(=O)[C@@]1(OC)O2)C(=O)C=C(NC1OC(C)C(OC)C(OC)C1OC)C4=O</smiles>

SF2446A2 (59)

HO<smiles>CCCCCCCCCCCCCC(=O)CCc1ccccc1</smiles><smiles>C#CCCCC/C=C/C#CCCCCCC(=O)NC(N)CCl</smiles>

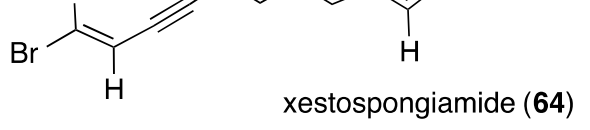

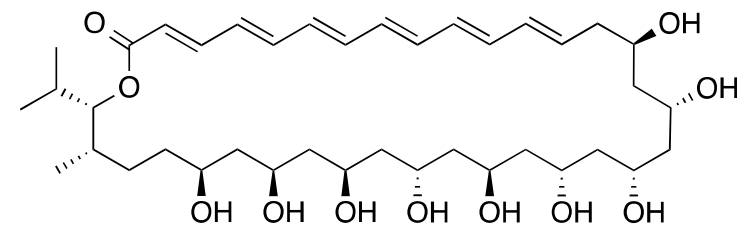
bahamaolide $\mathrm{A}(65)$

Figure 1. Cont. 
<smiles>C/C=C/C=C/C(=O)NC(C/C=C/C=C/CCC)C/C=C/C=C(C)/C=C/C=C\C(C)=C/C=C\C(O)CO</smiles>

heronamide $\mathrm{C}(\mathbf{6 6})$<smiles>COC(=O)C1=CC2=CC=Nc3c(NCCc4ccccc4)cnc(c31)C2=O</smiles>

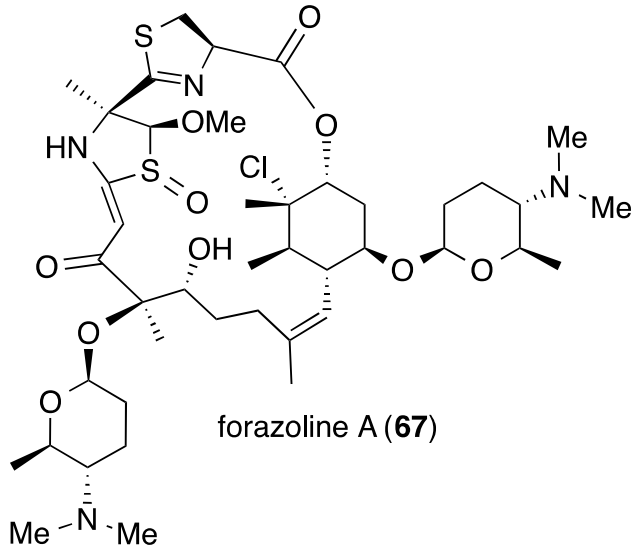<smiles>C=C(C)C/C=C/C(O)C(C)C/C(C)=C/C(=C)C(C)CC(O)CC(O)CO</smiles>

amphidinin G (69)

aaptamine derivative 68

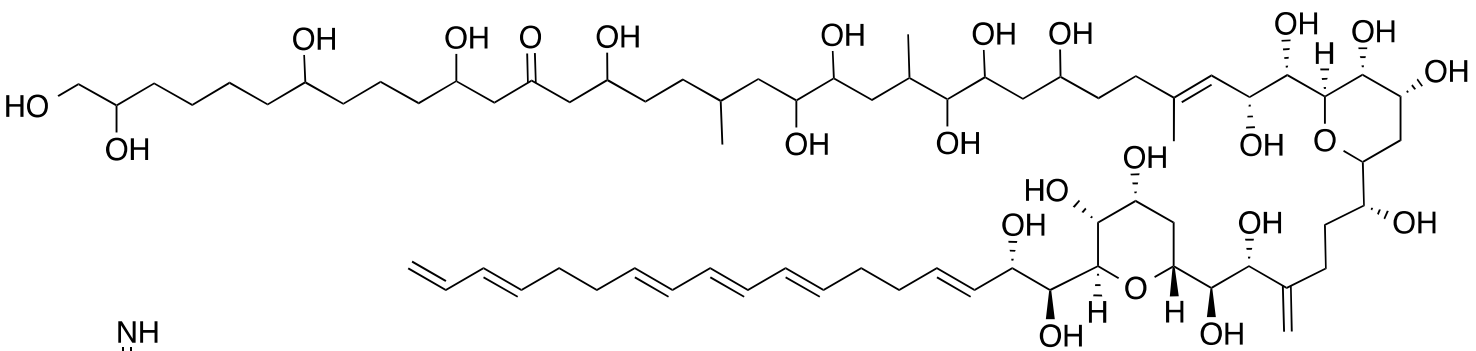
amphidinol 18 (70)<smiles>CCCCC1NC(=N)N2CCCC2=C1C(=O)OCCCCNC(=N)N</smiles>

crambescin A2 392 (71) $n=4$ crambescin A2 406 (72) $n=5$ crambescin A2 420 (73) $n=6$<smiles>CC/C=C\C/C=C\C/C=C\C/C=C\C/C=C\CCCCCCCC</smiles>

laurepoxyene (76)<smiles>Cc1cc2c(cc1Br)[C@@]1(C)CC[C@](C)(O)[C@@]1(C)O2</smiles>

3ß-hydroperoxyaplysin (77)<smiles>COc1c(C)c(O)cc(O)c1CC1=C(C)C(=O)C(O)=C(C)C1=O</smiles>

Figure 1. Cont. 

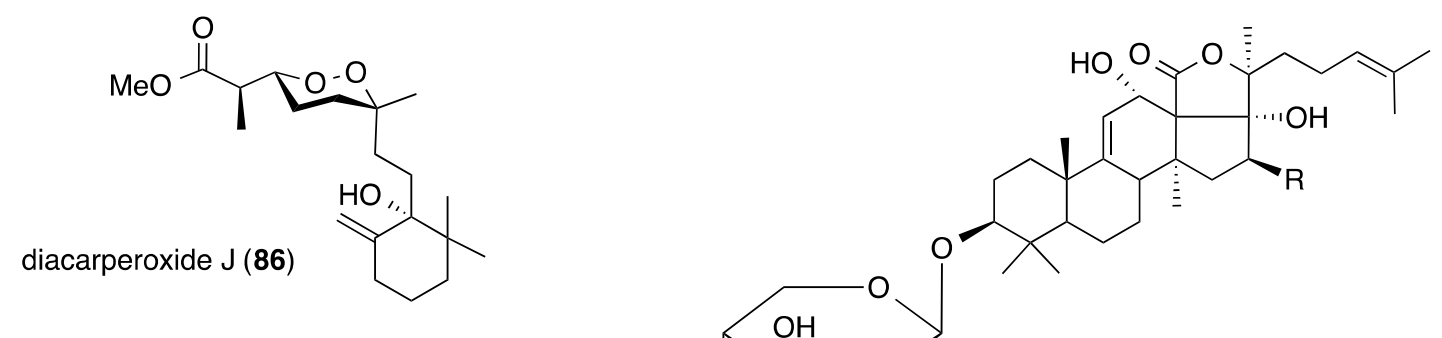

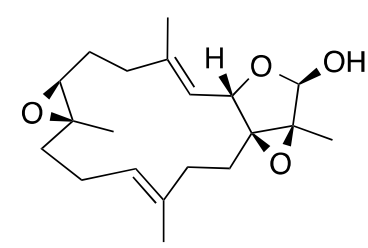

laevigatol $\mathrm{A}(\mathbf{8 7})$

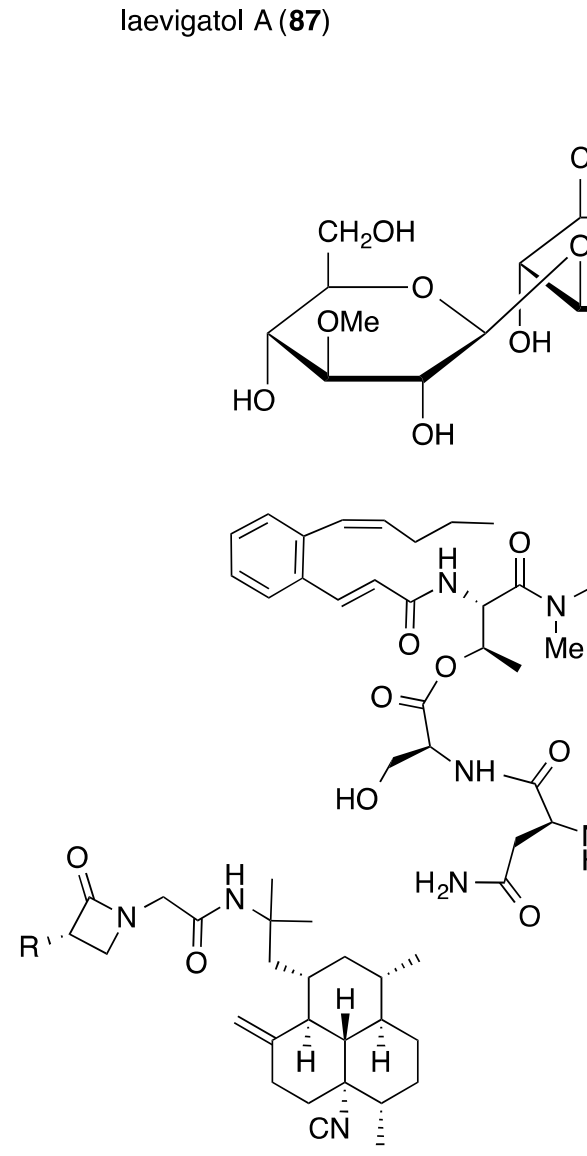

cousteside $\mathrm{C}(74) \mathrm{R}=\mathrm{OH}$ cousteside $D(75) R=O A c$

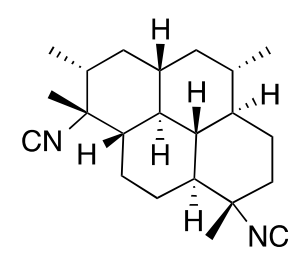

7,20-diisocyanoadociane (84)

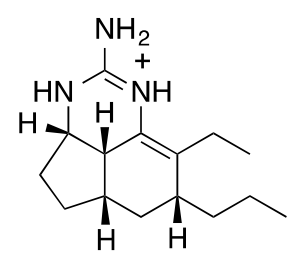

netamine $\mathrm{K}(90)$

monamphilectine $\mathrm{B}(\mathbf{8 8}) \mathrm{R}=\mathrm{CH}_{3}$

monamphilectine $\mathrm{C}(89) \mathrm{R}=\mathrm{OMe}$<smiles>CCC(C)(C)C/C=C\CCC#CCCC(=O)O[C@H](C)C[C@@H](CCC[C@H](O)CC(=O)NCCS(=O)(=O)O)OC(=O)OC(C)(C)C</smiles>

Figure 1. Cont. 


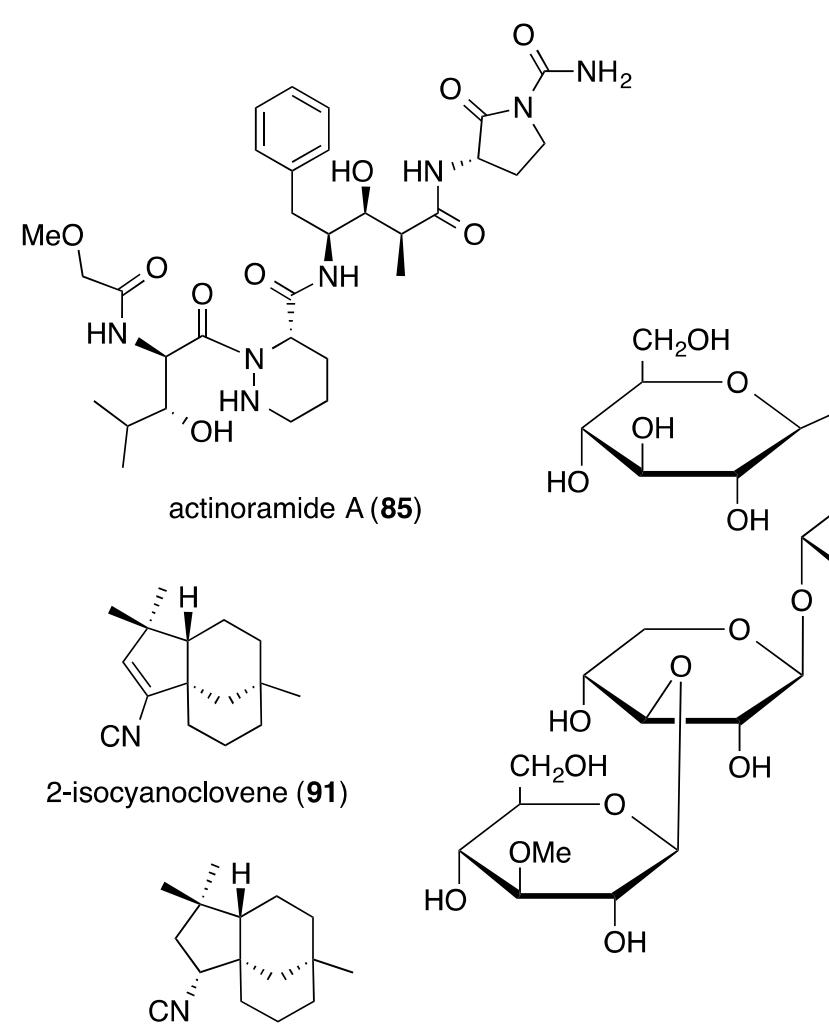

2-isocyanoclovane (92)<smiles>CCCC[C@H](CC)C[C@@](/C=C(/CC)[C@@H](CCOC)OO)(CC)OO</smiles>
endoperoxide polyketide 94

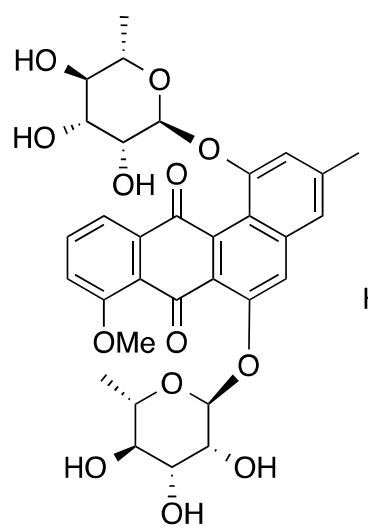

actinosporin $A(97)$

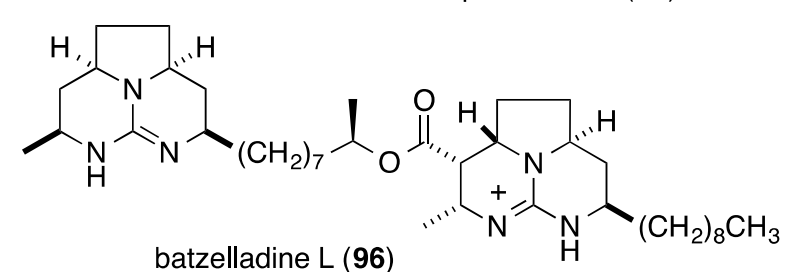<smiles>C=CC(O)(CCC(C)C1CCC2C3CCC4C[C@@H](O)CC[C@]4(C)C3=CC[C@@]12C)C(C)C</smiles><smiles>CC/C=C/C(CC)C/C(C)=C/[C@@H]1C[C@@](/C=C/C(=O)O)(CC)OO1</smiles>

plakortide $\mathrm{E}$ (95)

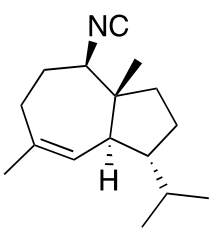

4,5-epi-10-isocyanoisodauc-6-ene (93)

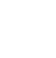




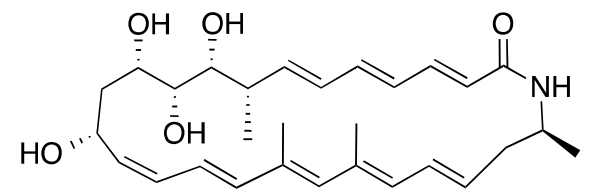

lobosamide A (100)

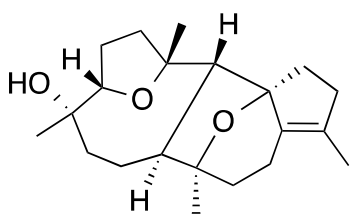

crassumol D (104)<smiles>CC1(C)CCC[C@@]2(C)C1CC[C@@]1(C)C2C[C@H](O)[C@@]2(C)C3=C(CCC12)C(=O)NC3=O</smiles>

sesterstamide (106)

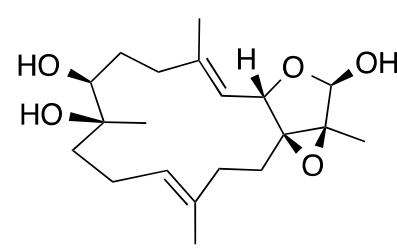

lobocrasol A (101)

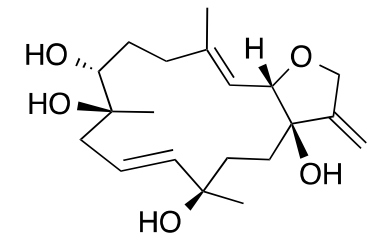

lobocrasol C (102)

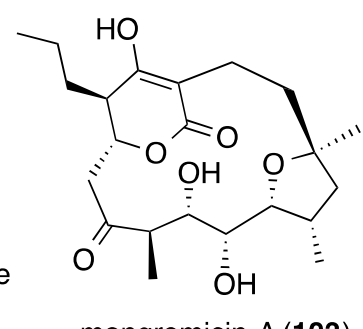<smiles>C=C(C)[C@@H]1[C@@H](OC(C)=O)C[C@@H](C)[C@H]2[C@@H](OC)C=C(C)[C@]12C</smiles>

shagene $A(\mathbf{1 0 7})$<smiles>C=C1CC[C@]2(O)C(=C)CO[C@H]2/C=C(\C)CCC[C@@]2(C)CC[C@H]1O2</smiles>
crassumol E (105)<smiles>C=C(OC)C(=CC)OC</smiles>

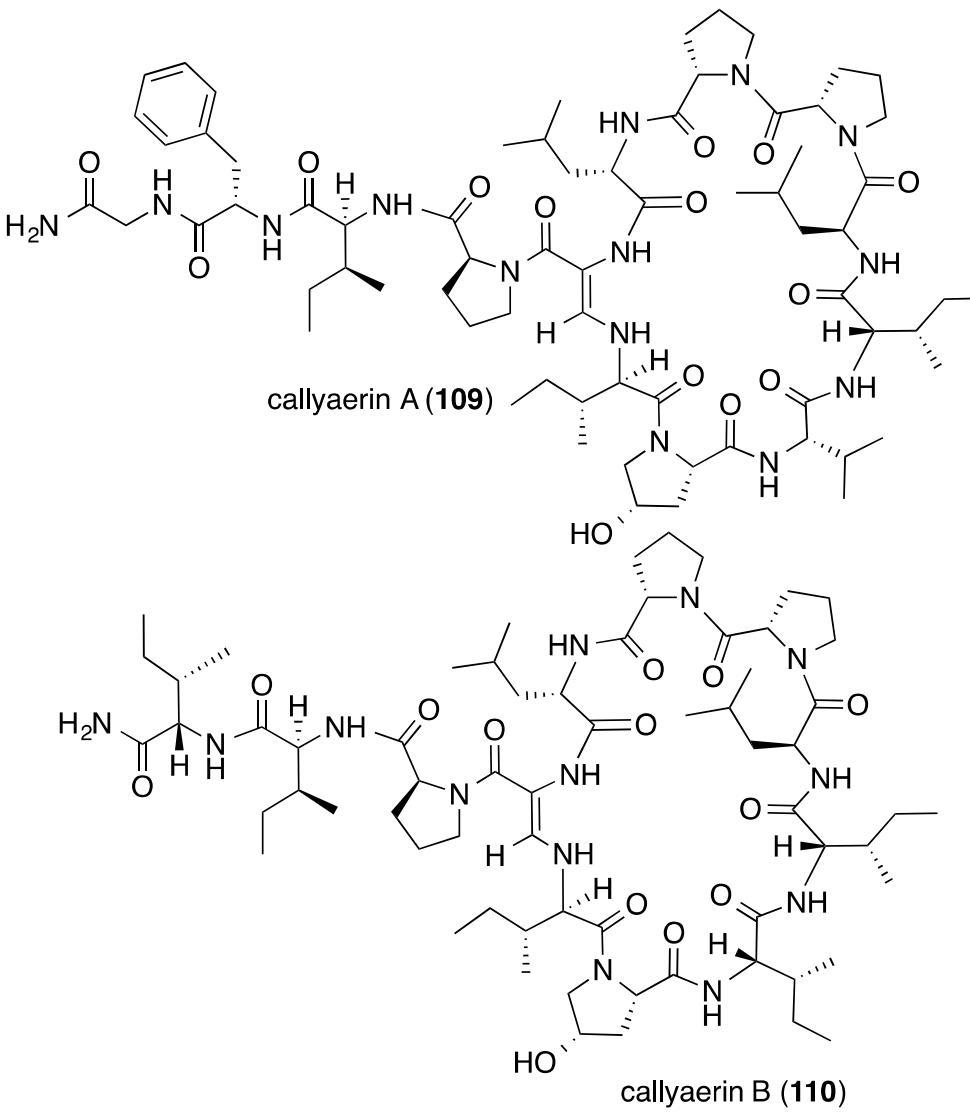
2-methoxy-3-oxoaaptamine (108)

$\mathrm{HO}$<smiles>[2H]c1ccc(C2=C3C(=C(c4ccc(O)cc4)C(=O)c4cc(O)ccc43)N(CCc3ccc(O)cc3)C2=O)cc1</smiles>

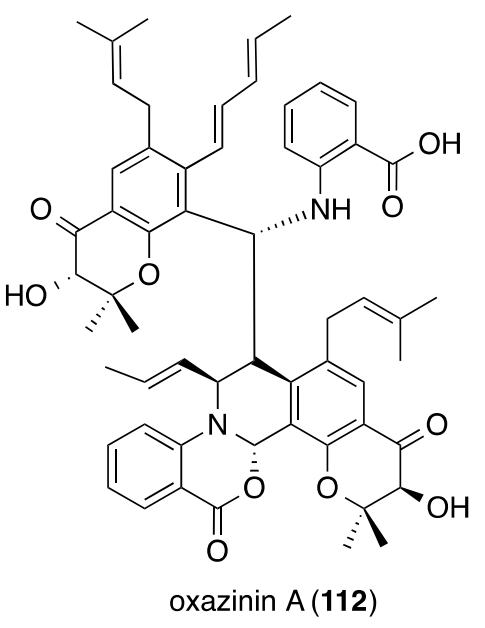

Figure 1. Cont. 


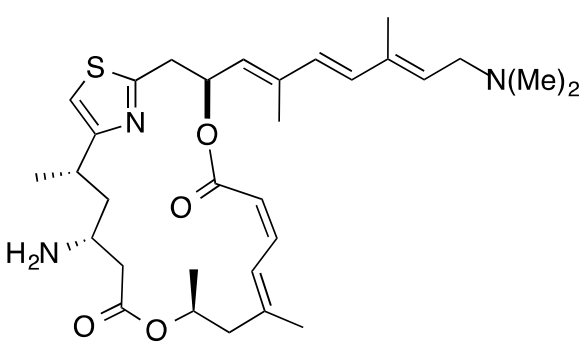

pateamine $A(\mathbf{1 1 3})$<smiles>CC1(C)CC(=O)C2=C(O1)C(Cl)C(O)[C@@H]1CC(C(C)(C)O)O[C@H]21</smiles>

truncateol M (116)

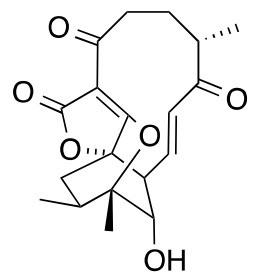

abyssomicin 2 (114)<smiles>C=CC(C)(C)c1[nH]c2ccccc2c1/C=c1\[nH]c(=O)c(=C)[nH]c1=O</smiles>

neoechinulin $B(117)$

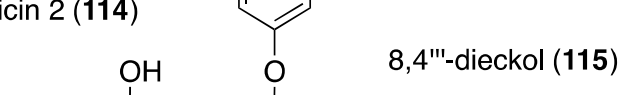

(115)<smiles>Oc1cc(O)c2c(c1)Oc1c(O)cc(O)cc1O2</smiles><smiles>c1ccoc1</smiles>

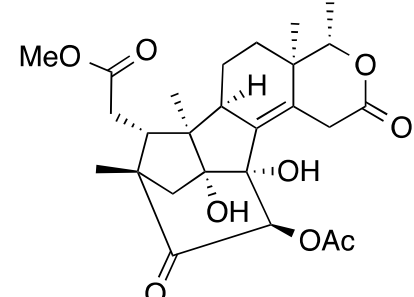

thaixylomolin I (118)

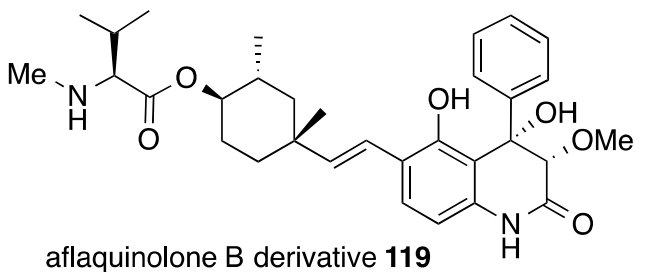

aflaquinolone $B$ derivative 119<smiles>C=C1CCC(O)(C(C)(C)C)/C=C/[C@H](C)CC[C@@H]1O</smiles>

chartarutine $B(\mathbf{1 2 2})$

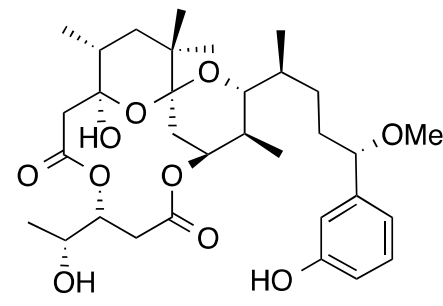

debromoaplysiatoxin (123)<smiles>Oc1cc(Br)c(P)c(Br)c1Oc1ccc(Br)cc1Br</smiles>

polybrominated diphenyl ether $22 \mathrm{R}=\mathrm{H}$ polybrominated diphenyl ether $23 \mathrm{R}=\mathrm{Br}$

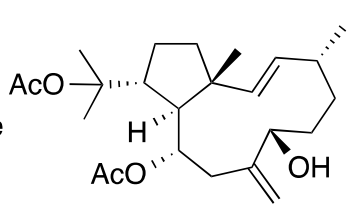<smiles>C=C1CC[C@@H](O)[C@@H]2C[C@H]3OC(=O)C4=C3C(C)(CC4)C[C@]12O</smiles>

13-deacetoxyamijidictyol (125)

dolabelladienol A (124)

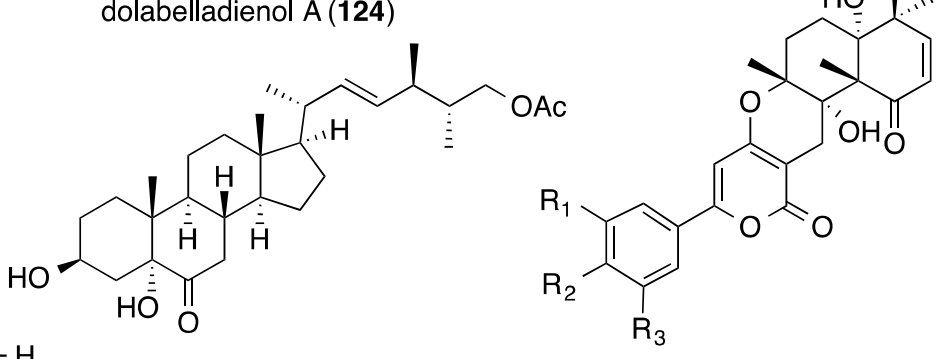
echrebsteroid C (126) territrem D (120) $R_{1}=O H \quad R_{2}=R_{3}=O M e$ arisugacin $A(121) R_{1}=R_{2}=O M e R_{3}=H$

Figure 1. Cont. 
<smiles>CCCCC1=C(C)CO[C@@H]1/C=C(\C)CC[C@@H](OC(=O)OCC(C)(C)C)[C@@]1(C)CCC(=O)O1</smiles><smiles>CC[C@H](C)C(=O)Nc1ncnc2[nH]cnc12</smiles>

phorioadenine $\mathrm{A}(\mathbf{1 3 3})$

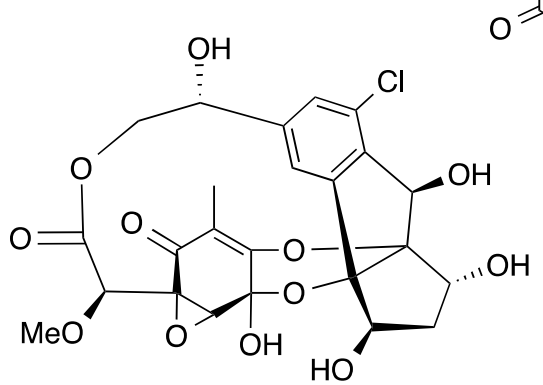<smiles>CCC(C)[C@H]1C(=O)/C(=C(/O)[C@H]2[C@H](C)C(C)=C[C@H]3CCC[C@H](C)[C@H]32)C(=O)N1C</smiles>

trichobotrysin A (132)

sporolide B (129)

Figure 1. Marine pharmacology in 2014-2015: marine compounds with antibacterial, antifungal, antiprotozoal, antituberculosis, antiviral, and anthelmintic activities.

\subsection{Antibacterial Activity}

During 2014-2015, 48 studies reported antibacterial marine natural products (1-64) isolated from bacteria, fungi, tunicates, sponges, soft corals, sea snakes, fish, and algae; a research enterprise focused on the discovery of novel chemical leads to treat emerging drug-resistant bacterial infections.

As shown in Table 1 and Figure 1, nine publications reported on the mode of action of marine-derived antibacterial compounds. Rodríguez and colleagues reported on "a practical synthesis of the axinellamines" $(\mathbf{1}, \mathbf{2})$, as well as their broad spectrum Gram-positive and Gram-negative antibacterial activity, probably resulting from "secondary membrane destabilization ... consistent with the inhibition of normal septum formation" [24]. Moon and colleagues characterized a new pentacyclic antibiotic, buanmycin (3), isolated from a Korean marine Streptomyces strain, which was active towards Gram-native Salmonella enterica that causes salmonellosis, by inhibiting sortase A, an enzyme involved 
in bacterial adhesion and proposed as a "promising target for antibiotic discovery" [25]. Wei and colleagues discovered a novel peptide cathelicidin (4) from the Chinese sea snake Hydrophis cyanocinctus with potent antimicrobial activity against 35 strains of 48 human pathogenic bacteria, probably by a mechanism that involved "disruption of cell membrane and lysis of bacterial cells ... resulting in cellular disruption of both Gram-positive and Gram-negative bacteria" [26]. Silva and colleagues demonstrated that the antimicrobial peptide clavanin A (5) significantly reduced E. coli and S. aureus-infected mice mortality with concomitant reduction of proinflammatory cytokines, thus proposing that clavalin $\mathrm{A}$ " ... will facilitate studies on the development of novel peptide-based strategies for the treatment of infected wounds and sepsis" [27]. Abdelmohsen and colleagues investigated the new sterol gelliusterol E (6) from the Red sea sponge Callyspongia aff. implexa and showed that it inhibited both the primary infection by Chlamydia trachomatis, an obligate intracellular Gram-negative bacterium, as well as the production of viable progeny, and thus the developmental cycle of this bacterium [28]. Pieri and colleagues described new ianthelliformisamine $B$ and $C(7,8)$ from the marine sponge Suberea ianthelliformis as antibiotic enhancers against resistant Gram-negative bacteria by a mechanism described as "altered proton homeostasis", and thus probably affecting drug transport [29]. Huang and colleagues showed that the antimicrobial peptide pardaxin (9) isolated from the Red sea flatfish Pardachirus marmoratus protected mice from a lethal dose of methicillin-resistant Staphylococcus aureus, while also accelerating wound healing, increasing monocytes' and macrophages' recruitment, as well as expression of vascular endothelial growth factor [30]. Eom and colleagues described the mechanism of antibacterial activity of the phlorotannin phlorofucofuroeckol-A (10) isolated from the edible brown alga Eisenia bicyclis, which was shown to involve suppression of several mec operon genes in methicillin-resistant Staphylococcus aureus as well as the production of penicillin-binding protein $2 \mathrm{a}$, considered as the "primary cause of methicillin resistance" [31]. Hassan and colleagues reported a new depsipeptide salinamide F (11), isolated from a marine-derived Streptomyces sp. strain CNB-091 that was observed to significantly inhibit RNA polymerase (RNAP) from both Gram-positive and Gram-negative bacteria, but "does not interact with the rifampin binding site on RNAP" [32].

As shown in Table 1 and Figure 1, 53 marine natural products (12-64), some of them novel, were reported to exhibit antibacterial activity with MICs $<10 \mu \mathrm{g} / \mathrm{mL}$ or $10 \mu \mathrm{M}$ against several Gram-positive and Gram-negative bacterial strains, although the mechanism of action for these compounds remained undetermined: two antimicrobial peptides, piscidins 3 and $4(\mathbf{1 2}, \mathbf{1 3})$ originally isolated from the fish tilapia Oreochromis niloticus [33]; a new bisthiodiketopiperazine adametizine A (14), isolated from a marine sponge-derived fungus Penicillium adametzioides AS-53 [34]; two dimeric bromopyrrole alkaloids agelamadins A and B (15, 16), isolated from the Okinawan marine sponge Agelas sp. [35]; a butyrolactone derivative (17), isolated from the fermentation broth of a South China sea gorgonian Muricella abnormalis-derived Aspergillus sp. XS-20090B15 fungus [36]; a meroditerpene aszonapyrone A (18), isolated from the Thai marine sponge Chondrilla asutraliensis-associated fungus Neosartorya paulistensis (KUFC 7897) [37]; a new meroterpenoid, austalide R (19), from a fungus Aspergillus sp. isolated from the Mediterranean sponge Tethya aurantium [38]; a novel citrifelin B (20) with a unique tetracyclic framework was characterized from a co-culture of marine-derived fungi Penicillium citrinum and Beauveria felina [39]; a novel cyclohexadepsipeptide desmethylisaridin C1 (21) identified from a marine bryozoan-derived fungus Beauveria felina EN-135 [40]; two novel polybrominated diphenyl ethers $(22,23)$, isolated from the cosmopolitan marine sponge Dysidea spp. [41]; a new pentacyclic cytochalasin diaporthalasin (24), isolated from the marine-derived fungus Diaporthaceae sp. PSU-SP2/4 [42]; natural brominated furanones $(\mathbf{2 5}, \mathbf{2 6})$, isolated from the marine alga Delisea pulchra [43]; a novel meroterpenoid aureol B (27), isolated from the Micronesian Dysidea sp. sponge [44]; a novel meroterpenoid dysidinoid A (28), isolated from the South China sea sponge Dysidea sp. [45]; a terpenoid fuscoside E peracetate (29) and a lipid batyl alcohol (30), isolated from the Colombian soft coral Eunicea sp. [46]; a new aromatic butyrolactone flavipesin A (31), isolated from a marine-derived endophytic fungus Aspergillus flavipes [47]; new non-cytotoxic lipopeptides gageopeptides A-D (32, 33, 34, 35) [48] and gageotetrins A-C (36, 37, 38) [49], isolated from a Korean marine-derived Bacillus subtilis strain 109GGC020; 
a new cyclic depsipeptide hormaomycin B (39), isolated from a Korean marine mudflat-derived actinomycete Streptomyces sp. strain SNM55 [50]; a new glycolipid ieodoglucomide C (40) from the Korean marine-derived bacterium Bacillus licheniformis strain 09IDYM23 [51]; a new polycyclic tetramic acid macrolactam isoikarugamycin (41) from Equatorial Guinean Streptomyces zhaozhouensis strain CA-185989 [52]; a bromopyrrole alkaloid keramadine (42), isolated from the Okinawan marine sponge Agelas sp. [53]; "unprecedented" 9,11 secosterols with "the 2-ene-1,4-dione moiety" (43, 44) from the Korean marine sponge Ircinia sp. [54,55]; two polybrominated diphenyl ethers $(45,46)$ from the Papuan New Guinea marine sponge Lendenfeldia dendyi and the soft coral Sinularia dura [56]; a novel polyketide lindgomycin (47) from the Baltic sea and Arctic Lindgomycetaceae family marine fungal strains KF970 and LF327 [57]; a novel cycloheptadepsipeptide marfomycin D (48), isolated from a South China marine Streptomyces drozdowiczii SCSIO 10141 [58]; an glycohexadepsipeptide-polyketide mollemycin A (49) from an Australian marine-derived Streptomyces sp. strain CMB-M0244 [59]; a novel laurene-type sesquiterpene neolaurene (50) from a Bornean marine alga Laurencia nangii [60]; a new polyketide and ambuic acid analogue penicyclone A (51), isolated form an extract from a deep-sea derived fungus Penicillium sp. F23-2 [61]; a new phenolic enamide (52), characterized from the Chinese marine alga Codium fragile-derived endophytic fungus Penicillium oxalicum strain EN-290 [62]; a novel meroterpenoid puupehenol (53), isolated from a Hawaiian sponge Dactylospongia sp. [63]; a new scalarane sesterpene phyllospongin E (54), isolated from the Egyptian Red sea sponge Phyllospongia lamellosa [64]; two new rare pyrane-based cembranoids sarcotrocheliol acetate (55) and sarcotrocheliol (56), isolated from the Red sea soft coral Sarcophyton trocheliophorum [65]; a novel depsidone-based analogue spiromastixone J (57), isolated from the fermentation broth of a deep-sea Spiromastix sp. fungus [66]; a new spirocyclic drimane stachyin B (58), identified in the mycelia and culture broth of a North sea Stachybotrys sp. fungus strain MF347 [67]; a naphthacene glycoside SF2446A2 (59), isolated from a culture of Streptomyces sp. strain RV15 derived from the Mediterranean sponge Dysidea tupha [68]; three new subergosterones A-C (60-62), obtained from the South China sea gorgonian coral Subergorgia rubra [69]; an amino-polyketide vitroprocine A (63), isolated from the marine bacterium Vibrio sp. strain QWI-06 [70]; and a new polyacetylene derivative xestospongiamide (64), isolated from the Red sea sponge Xestospongia sp. [71].

Furthermore, during 2014-2015, several other marine natural products, some of them novel, reported antimicrobial activity in MICs or $\mathrm{IC}_{50}$ 's ranging from 10 to $50 \mu \mathrm{g} / \mathrm{mL}$, or 10-50 $\mu \mathrm{M}$, respectively, and thus, because of their lower antibacterial potency, were excluded from Table 1 and Figure 1: tetracyclic sesterterpenes from a Korean marine sponge Clathria gombawuiensis sp. (MIC $=6.25-25 \mu \mathrm{g} / \mathrm{mL}$ ) [129]; the antimicrobial peptide isolated from the mucus of the hagfish Myxine glutinosa and several structural analogs (MICs = 1.2-50 $\mu \mathrm{M})$ [130]; bromopyrrole alkaloids agelamadins C-E $\left(\mathrm{IC}_{50}=32 \mu \mathrm{g} / \mathrm{mL}\right)$ from the Okinawan marine sponge Agelas sp. [131]; a new indole diterpenoid from the fungus Aspergillus flavus $(\mathrm{MIC}=20.5 \mu \mathrm{M})$, isolated from the Chinese prawn Penaeus vannamei [132]; two new bromopyrrole alkaloids isolated from the Okinawan sponge Agelas sp., namely 2-debromomonagelamide U and 2-debromomukanadin $\mathrm{G}(\mathrm{MIC}=32 \mu \mathrm{g} / \mathrm{mL})$ [133]; seven known and one new sesquiterpene named epoxysubergorgic acid isolated from the Chinese gorgonian coral S. suberosa (MIC>8 $\mu \mathrm{g} / \mathrm{mL})$ [134]; a new bromotyrosine alkaloid aplysamine $8(\mathrm{MIC}=31 \mu \mathrm{g} / \mathrm{mL})$ from an Australian marine sponge Pseudoceratina purpurea [135], alternariol derivatives (MIC $=50 \mu \mathrm{g} / \mathrm{disk}$ ) from the endophytic fungus Alternaria alternata isolated from the Red sea soft coral Litophyton arboretum [136]; new polyketides amphidins C-F (MIC $=16$ and $32 \mu \mathrm{g} / \mathrm{mL})$, isolated from the culture broth of dinoflagellate Amphidinium sp. [137]; a new 1-deoxysphingoid, 3-epi-xestoaminol C $(\mathrm{MIC}=32.6 \mu \mathrm{M})$, isolated from the New Zealand brown alga Xiphophora chondrophylla [138]; a new cyclic pentapeptide, asperpeptide A (MIC = 12.5 $\mu \mathrm{M})$, isolated from the gorgonian-derived fungus Aspergillus sp. [139]; a nucleoside derivative, kipukasin $\mathrm{H}$ $(\mathrm{MIC}=12.5 \mu \mathrm{M})$, isolated from the fungus $A$. versicolor derived from the Xisha islands, South China sea gorgonian D. gemmacea [140]; a new O-containing heterocyclic compound named felinone B $(\mathrm{MIC}=32 \mu \mathrm{g} / \mathrm{mL})$ from an extract of B. feline EN-135, a fungus isolated from an unidentified marine bryozoan [141]; new xanthone microluside A (MIC $=10-13 \mu \mathrm{M})$ from a Red sea marine 
sponge S. vagabunda-derived Micrococcus sp. EG45 [142]; a new cyclohexapeptide desotamide B $(\mathrm{MIC}=12-16 \mu \mathrm{g} / \mathrm{mL})$ from a South China sea marine microbe S. scopuliridis SCSIO ZJ46 [143]; new linear lipopeptides (MIC = 16 and $32 \mu \mathrm{g} / \mathrm{mL}$ ) from a Korean marine Bacillus subtillis [144]; a new streptophenazine K $(\mathrm{MIC}=14.5-21.6 \mu \mathrm{M})$ from bacteria isolated from a Baltic sea sponge Halichondria panacea [145]; a novel polyketide amantelide A $(\mathrm{MIC}=32 \mu \mathrm{M})$ from a Guamanian Oscillatoriales cyanobacterium [146]; a novel echinomycin analog, quinomycin G (MIC = 16-64 $\mu \mathrm{g} / \mathrm{mL}$ ), isolated from Streptomyces sp. LS298 from a Hainan marine sponge Gelliodes carnosa [147]; and new cyclic lipopeptides gageopeptins $\mathrm{A}$ and $\mathrm{B}(\mathrm{MIC}=6$ and $32 \mu \mathrm{g} / \mathrm{mL})$ from a marine-derived strain Bacillus sp. 109GGC020 [144].

\subsection{Antifungal Activity}

Sixteen studies during 2014-2015 reported on the antifungal activity of several marine natural products (64-83) isolated from marine bacteria, dinoflagellates, sponges, sea cucumbers, and algae, a slight increase from our last review [9] and previous reviews of this marine pharmacology series.

As shown in Table 1 and Figure 1, three reports described antifungal marine chemicals with novel mechanisms of action. Lee and colleagues investigated the new macrocyclic lactone antifungal bahamaolide A (65) isolated from the culture of marine actinomycete Streptomyces sp. CNQ343 [72]. Detailed studies determined that the compound inhibited isocitrate lyase (ICL) mRNA expression, suggesting it might be used for treatment of "C. albicans infections via inhibition of ICL activity". Sugiyama and colleagues characterized the biological activity of the polyene macrolactam heronamide C (66) isolated from a marine-derived Streptomyces sp. [73]. The heronamide C was shown to induce abnormal cell wall morphology by "perturbing membrane microdomains". Wyche and colleagues reported a novel marine-derived polyketide forazoline A (67) isolated from an Actinomadura sp. strain WMMB-499 cultivated from the ascidian Ecteinascidia turbinata [74]. Using chemical genomics, the authors proposed forazoline A worked in vivo in mice against the fungus Candida albicans by affecting cell membrane integrity by a "novel mechanism of action from known antifungal agents".

As shown in Table 1 and Figure 1, several marine natural products showed antifungal activity with MICs that were either less than $10 \mu \mathrm{g} / \mathrm{mL}, 10 \mu \mathrm{M}$, or $10 \mu \mathrm{g} / \mathrm{disk}$, but no mechanism of action studies were reported in the papers: an alkaloid aaptamine derivative (68), isolated from the South China sea sponge Aaptos aaptos [75]; a new linear polyketide amphidinin G (69), isolated from a Japanese symbiotic marine dinoflagellate Amphidinium sp. discovered in a marine flatworm Amphiscolops sp. [76]; a new polyketide amphidinol 18 (70), isolated from the dinoflagellate Amphidinium carterae strain CCMP121 [77]; new crambescin A2 (71-73), alkaloid homologues from the Bahamian marine sponge Pseudaxinella reticulata [78]; two new saponins cousteside C (74) and D (75), reported from the Egyptian Red sea cucumber Bohadschia cousteaui [79]; two new laurane-type sesquiterpenes, laurepoxyene (76) and $3 \beta$-hydroxyperoxyaplysin (77), and a new polyunsaturated fatty acid ethyl ester (78), isolated from the Chinese red alga Laurencia okamurai [80,81]; a novel dilactone-tethered pseudo-dimeric peptide mohangamide A (79), isolated from a Korean marine Streptomyces sp. [82]; a novel pleosporallin E (80), isolated from a marine fungus Pleosporales sp., discovered on the South China sea alga Enteromorpha clathrata [83]; a lysophospholipid (81), isolated from the South China sea sponge Spirastrella purpurea [84]; an acetylenic fatty acid derivative taurospongin A (82) from an Okinawan marine sponge SS-1202, family Spongiidae [85], and a new non-sulphated triterpene glycoside variegatuside D (83) from the south China sea cucumber Stichopus variegates [86]. Mechanism of action studies will be required to characterize the antifungal pharmacology of these marine-derived natural compounds.

In addition, novel structurally-characterized marine molecules with antifungal MICs or $\mathrm{IC}_{50}$ 's greater than $10 \mu \mathrm{g} / \mathrm{mL}, 10 \mu \mathrm{M}$, or $10 \mu \mathrm{g} /$ disk, which have been excluded from Table 1 and Figure 1 because of their weaker bioactivity: a new bromopyrrole alkaloid mukanadine $\mathrm{G}$ $\left(\mathrm{IC}_{50}=8-16 \mu \mathrm{g} / \mathrm{mL}\right)$ isolated from the Okinawan marine sponge Agelas sp. [53]; a new C24-acetylenic acid, biemnic acid (MIC $=100 \mu \mathrm{g} /$ disk) isolated from the Red sea sponge Biemna ehrenbergi [148]; two sulfated steroid-aminoacid conjugates isolated from the Irish marine sponge Polymastia boletiformis 
$(\mathrm{MIC}=100 \mu \mathrm{g} /$ disk$)$ against C. albicans [149]; two novel lysophospholids from the Guanxi sponge S. purpurea $\left(\mathrm{IC}_{50}=16\right.$ and $32 \mu \mathrm{g} / \mathrm{mL}$ ) [84]; two new bromotyrosine alkaloids, tyrokeradine $\mathrm{G}$ and $\mathrm{H}$, isolated from an Okinawan Verongid marine sponge (MIC $=16$ and $32 \mu \mathrm{g} / \mathrm{mL}$ ) [150]; two highly brominated polyphenols isolated from the Qingdao red alga S. latiuscula (MIC = 12.5, $25 \mu \mathrm{g} / \mathrm{mL}$ ) [151]; one novel anhydride metabolite, tubingenoic anhydride $\mathrm{A}(\mathrm{MIC}=330 \mu \mathrm{M})$, from the Mediterranean fungus $A$. tubingensis (Strain OY907) [152]; and a novel compound terretrione D (MIC = $32 \mu \mathrm{g} / \mathrm{mL}$ ) from a tunicate-derived fungus Penicillium sp. CYE-97 [153]. These novel marine compounds may contribute to the antifungal preclinical and clinical pipeline upon further research.

\subsection{Antiprotozoal and Antituberculosis Activity}

As shown in Table 1, during 2014-2015, twenty-four studies contributed to novel findings on antiprotozoal (antimalarial, antileishmanial, and antitrypanosomal) and antituberculosis pharmacology of structurally characterized marine natural products (84-112), very similar to our previous 1998-2013 marine pharmacology reviews [1-9].

Malaria, a global disease caused by protozoan genus Plasmodium (P. falciparum, P. ovale, P. vivax and P. malariae), currently affects over 2 billion people worldwide. Contributing to the global search for novel antimalarial drugs, and as presented in Table 1, 11 marine molecules (84-94) isolated from bacteria, molluscs, sponges, and soft corals were shown during 2014-2015 to possess antimalarial activity. Young and colleagues reported a detailed mechanistic study with the marine sesquiterpene isonitrile 7,20-diisocyanoadociane (84) originally isolated from the marine sponge Cymbastela hooperi [87], demonstrating that it inhibited $\beta$-hematin $\left(\mathrm{IC}_{50}=13 \mathrm{nM}\right)$, and thus interfered with the parasite's heme detoxification pathway.

As shown in Table 1 and Figure 1 , potent $\left(\mathrm{IC}_{50}<2 \mu \mathrm{M}\right)$ to moderate $\left(\mathrm{IC}_{50}>2-10 \mu \mathrm{M}\right)$ antimalarial activity was reported for several marine natural products (85-94), although the mechanism of action for these compounds remained undertermined at the time of publication. Cheng and colleagues reported potent antiplasmodial activity in the peptide actinoramide A (85) isolated from Streptomyces species "in all five (P. falciparum) lines retested" [88]. Yang and colleagues discovered that a novel norditerpene diacarperoxide J (86) isolated from the South China Sea sponge Diacarnus megaspinorhabdosa was a moderate growth inhibitor of P. falciparum D6 clone, and observed that the peroxy functional group might be a "potential pharmacophore" [89]. Thao and colleagues characterized cembranoid diterpene laevigatol A (87) from several Vietnamese soft corals with potent antimalarial activity against drug sensitive $P$. falciparum strain NF54 [90]. Raju and colleagues showed that the glycohexadepsipeptide-polyketide mollemycin A (49) isolated from an Australian marine-derived Streptomyces sp. strain CMB-M0244 strongly inhibited drug sensitive P. falciparum strain 3D7 and multidrug resistant strain Dd2 [59]. Avilés and colleagues noted that isocyanide amphilectane-type diterpenes monamphilectines $B$ and $C(\mathbf{8 8}, \mathbf{8 9})$, isolated from the Caribbean sponge Svenzea flava, exhibited strong inhibitory activity against P. falciparum strain 3D7 [91]. Gros and colleagues observed that among the novel tricyclid alkaloids isolated from the Madagascar marine sponge Biemna laboutei netamine K (90) exhibited inhibitory activity against several P. falciparum strains [92]. White and colleagues reported several novel isocyano/isothiocyanate sesquiterpenes (91-93) isolated from the nudibranch Phyllidia ocellata that showed strong antiplasmodial activity against drug resistant P. falciparum Dd2 and 3D7 strains [93]. Chianese and colleagues assessed antimalarial activity of the novel endoperoxide polyketide (94) from the South China sea marine sponge Plakortis simplex against the P. falciparum chloroquine-sensitive D10 and chloroquine-resistant W2 strains [94].

As shown in Table 1 and Figure 1, thirteen marine compounds (95-107) isolated from bacteria, fungi, sponges, and soft corals were reported to possess bioactivity towards the so-called neglected protozoal diseases: leishmaniasis, caused by the genus Leishmania (L.); amebiasis, trichomoniasis, as well as African sleeping sickness (caused by Trypanosoma (T.) brucei rhodesiense and T. brucei gambiense), and American sleeping sickness or Chagas disease (caused by T. cruzi). 
As shown in Table 1, two reports described two antitrypanosomal marine chemicals $(95,96)$ as well as their mechanisms of action. Oli and colleagues examined the mode of action of plakortide E (95), isolated from the sponge Plakortis halichondrioides, and demonstrated that it inhibited activity of T. brucei by a non-competitive, covalent or "mechanisms leading to slow-binding", reversible inhibition of the parasite's enzyme rhodesain [95]. Santos and colleagues extended the pharmacology of guanidine and pyrimidine alkaloids from the Brazilian marine sponge Monanchora arbuscula, and reported that batzelladine L (96) affected both trypomastigotes of T. cruzi and L. infantum promastigotes, demonstrating that several mechanisms including altered plasma membrane permeability, mitochondrial membrane depolarization, and increased reactive oxygen species, probably contributing to "parasite cell death" [96].

As shown in Table 1 and Figure 1, eleven additional marine natural products (97-107) exhibited antileishmanial and antiprotozoal activity, although their mechanisms of action remained undetermined. Abdelmohsen and colleagues reported that a new O-glycosylated angucycline actinosporin A (97), isolated from a culture of Actinokineospora sp. strain EG49 cultivated from a Red sea sponge Spheciospongia vagabunda, moderately inhibited the growth of T. brucei brucei [97]. Thao and colleagues isolated the terpenoid astropectenol A (98) from a Vietnamese marine sea star Astropecten polyacanthus, and observed significant activity against T. cruzi and T. brucei brucei [98]. Viegelmann and colleagues identified a new saringosterol derivative (99) from the Irish marine sponge Haliclona simulans, which demonstrated antitrypanosomal activity against T. brucei brucei [99]. Using genome-directed lead discovery, Schulze and colleagues contributed a novel polyene macrolactam lobosamide A (100) from a marine actinobacterium Micronospora sp. that was highly active towards the parasite T. brucei brucei, "likely via a parasite-specific mechanism" that remained undetermined [100]. Thao and colleagues assessed the cembranoid diterpenes lobocrasols $A$ and $C(\mathbf{1 0 1}, \mathbf{1 0 2})$, and crassumols $D$ and E $(\mathbf{1 0 4}, \mathbf{1 0 5})$, isolated from several Vietnamese soft corals, and noted that they displayed potent activity against L. donovani amastigotes and T. brucei rhodesiense, respectively [90]. Nakashima and colleagues found a new cyclopentadecane antibiotic mangromicin A (103) separated from the culture broth of the fungus Lechevalieria aerocolonigenes K10-0216 isolated from a Japanese mangrove sediment with potent activity against T. brucei brucei strain GUTat 3.1 [101]. Yang and colleagues characterized a new scalarane sesterterpene sesterstamide (106) isolated from the Paracel islands marine sponge Hyrtios sp. that moderately inhibited L. donovani promastigotes [102]. Von Salm and colleagues contributed a novel tricyclic sesquiterpenoid shagene A (107) from an "undescribed" soft coral collected from the "Scotia Arc in the Southern Ocean" that was moderately active against L. donovani [103].

Drug-resistant strains of the intracellular pathogen Mycobacterium tuberculosis have stimulated a search for novel drug leads with novel mechanisms of action, and, as shown in Table 1 and Figure 1, five novel marine natural products (108-112) isolated from sponges and fungi evidenced promising activity, and thus contributed to the ongoing global search for novel antituberculosis agents during 2014-2015.

Arai and colleagues identified a novel aaptamine class alkaloid, 2-methoxy-3-oxoaaptamine (108), from a marine sponge Aaptos sp. that demonstrated strong inhibitory activity against M. smegmatis in "both active growing and dormancy-inducing hypoxic conditions" [104]. Daletos and colleagues isolated cyclic peptides callyaerins A and B $(\mathbf{1 0 9}, \mathbf{1 1 0})$, from the Indonesian sponge Callyspongia aerizusa, that demonstrated potent antibacterial activity against $M$. tuberculosis, highlighting the "potential of these compounds as promising anti-TB agents" [105]. Kumar and colleagues established that a new diarylpyrrole alkaloid denigrin C (111) from an extract of the Indian marine sponge Dendrilla nigra exhibited strong $M$. tuberculosis $\mathrm{H}_{37} \mathrm{Rv}$ activity "with a probable novel mechanism needed for antitubercular drug design ..." [106]. Lin and colleagues characterized a racemic, prenylated polyketide dimer, oxazinin A (112) from a filamentous fungus isolated from the Papua New Guinea ascidian Lissoclinum patella, which showed activity against $M$. tuberculosis with modest activity towards human transient receptor potential channels [107]. 


\subsection{Antiviral Activity}

As shown in Table 1 and Figure 1, twenty-one reports were published during 2014-2015 on the antiviral pharmacology of marine natural products (113-132) against human enterovirus 71, human cytomegalovirus, human immunodeficiency virus type-1 (HIV-1), human herpes simplex virus (HSV), influenza virus, hepatitis B virus, murine norovirus, respiratory syncytial virus (RSV), and sindbis virus.

As shown in Table 1, five reports described antiviral marine chemicals and their mechanisms of action. González-Almela and colleagues extended the pharmacology of pateamine A (113), isolated from the marine sponge Mycale sp. by demonstrating that the compound affected the translation of genomic and subgenomic mRNAs from Sindbis virus, although "subgenomic mRNA translation (was) more resistant to pateamine A inhibition" [108]. León and colleagues identified abyssomicin 2 (114) from a marine-derived actinobacterium Streptomyces sp. that reactivated human immunodeficiency virus type- 1 (HIV-1) by a protein kinase $C$ and histone deacetylase-independent mechanism that "remains to be elucidated" [109]. Karadeniz and colleagues reported that the anti-HIV activity of the phlorotannin derivative 8,4"'-dieckol (115) from the Korean brown alga Ecklonia cava included the "ability to act against drug-resistant HIV-1 strains" by a mechanism that involved inhibition of cytopathic effects, as well as inhibition of HIV-1 reverse transcriptase enzyme [110]. Zhao and colleagues established that truncateol M (116) isolated from a culture of the sponge-associated fungus Truncatella angustata demonstrated potent activity against influenza A infections by a mechanism that targeted the virion assembly and release step, putatively becoming "a model structure of antiviral lead for further modification" [111]. Chen and colleagues determined that the alkaloid neoechinulin B (117) isolated from the marine-derived fungus Eurotium rubrum showed potent inhibition of H1N1 influenza A virus by binding to the influenza virion envelope hemagglutin, thus "disrupting its interaction with the sialic acid receptor" on host cells [112].

An additional 15 marine natural products (118-132), listed in Table 1 and shown in Figure 1, demonstrated antiviral activity, but the mechanism of action of these compounds remained undetermined at the time of publication. Li and colleagues isolated a novel khayanolide, thaixylomolin I (118) from the seeds of the Trang (South Thailand) mangrove plant Xylocarpus moluccensis, which inhibited potent activity against influenza virus strain H1N1 [113]. Chen and colleagues contributed a new prenylated dihydroquinolone derivative 22-O-(N-Me-L-valyl)-21-epi-aflaquinolone B (119), produced by the mycelia of an Aspergillus sp. fungus derived from a South China Sea gorgonian Muricella abnormaliz, that inhibited respiratory syncytial virus influenza A virus H1N1 "with a high therapeutic ratio" [114]. Nong and colleagues found that two novel lactones territrem D and arisugacin A $(\mathbf{1 2 0}, \mathbf{1 2 1})$ from a fungus Aspergillus terreus SCSGAF0162 derived from a South China sea gorgonian Echinogorgia aurantiaca exhibited HSV-1 activity "under non-cytotoxic concentrations" [115]. $\mathrm{Li}$ and colleagues isolated a novel isoindolinone-type alkaloid chartarutine B (122) from the marine sponge-associated fungus Stachybotrys chartarum, which displayed moderate inhibitory activity HIV-1, noting that "side chain variation directly affected the inhibitory effects" [116]. Gupta and colleagues purified debromoaplysiatoxin (123) from the marine Singaporan cyanobacterium Trichodesmium erythraeum, which inhibited Chikungunya virus with "minimal cytotoxicity", and probably targeted the viral replication cycle after "viral entry" [117]. Pardo-Vargas and colleagues reported that the new diterpene dolabelladienol A (124) isolated from the Brazilian marine brown alga Dictyota pfaffii had potent activity against HIV-1 and, owing to "low cytotoxicity", appeared to be a "promising anti-HIV-1 agent" [118]. Cheng and colleagues noted that one of the dolastane diterpenes isolated from the South China sea brown alga Dictyota plectens, namely 13-deacetoxyamijidictyol (125), showed inhibitory activity against wild-type HIV-1 replication, thus proposing that "Dictyota algae may be a potential source of antiviral lead compounds" [119]. Yamashita and colleagues investigated the effect of two polybrominated diphenyl ethers $(\mathbf{2 2}, \mathbf{2 3})$ isolated from the Indonesian marine sponge Dysidea granulosa on the hepatitis B virus (HBV) core promoter activity, as well as the production of HBV DNA, suggesting that they may become "candidate lead compounds for the development of anti-HBV drugs" [120]. 
Cao and colleagues discovered that a new steroid echrebsteroid C (126) from the South China sea gorgonian Echinogorgia rebekka evidenced high activity against respiratory syncytial virus, a common cause of lower respiratory tract disease in infants and children, as well as a high therapeutic index, thus "suggesting it might be useful as a potential antiviral agent" [121]. Jia and colleagues showed that one of two enantiomeric dimers, namely (+)-pestaloxazine A (127), isolated from a Pestalotiopsis sp. fungus derived from a soft coral, showed potent antiviral activity towards enterovirus 71, a small, single-stranded RNA virus that may cause hand, foot, and mouth disease associated with neurological complications in children and infants [122]. Eom and colleagues evaluated phlorofucofuroeckol-A (10), isolated from the edible brown alga Eisenia bicyclis against murine norovirus, a leading cause of gastroenteritis, noting that, because of its strong anti-norovirus activity and high therapeutic index, it appeared "phlorotannins could be used as a potential source of natural antiviral agents" [123]. Cheng and colleagues discovered a new seco-cembranoid secocrassumol (128) from the marine soft coral Lobophytum crassum, which showed significant activity against human cytomegalovirus, a common herpesvirus infection in humans [124]. Using ligand-based pharmacophore mapping, Dineshkumar and colleagues demonstrated that the polycyclic macrolide sporolide B (129) isolated from the marine actinomycete Salinispora tropica showed significant inhibition of the HIV-1 reverse transcriptase, and thus "could be a possible drug candidate for HIV" [125]. Shin and colleagues isolated two new depsipeptides stellettapeptins A and B $(\mathbf{1 3 0}, \mathbf{1 3 1})$ from an extract of the Australian marine sponge Stelletta sp. with significant HIV-inhibitory properties, suggesting that "this class of peptides may hold promise as anti-HIV agents" [126]. Sun and colleagues characterized a new tetramic acid derivative trichobotrysin A (132) isolated from the culture of South China sea Trichobotrys effuse DFFSCS021 that inhibited herpes simplex virus type-1, responsible for lifelong oral infections in humans [127].

\subsection{Anthelmintic Activity}

As shown in Table 1, only one report was published during 2014-2015 on the anthelmintic pharmacology of marine natural products. Farrugia and colleagues isolated a $6-\mathrm{N}$-acyladenine alkaloid, phorioadenine A (133), from the southern Australian marine sponge Phoriospongia sp., which displayed “... nematocidal activity against $H$. contortus ... slightly weaker than commercial anthelmintics levamisole and closantel", perhaps suggesting that this compound may become a promising lead compound for the development of new anthelmintics [128].

\section{Marine Compounds with Antidiabetic and Anti-Inflammatory Activity, and Affecting the Immune and Nervous System}

Table 2 presents the 2014-2015 preclinical pharmacology of marine chemicals (134-218), which demonstrated either antidiabetic or anti-inflammatory activity, as well as affected the immune or nervous system, and whose structures are depicted in Figure 2. 
Table 2. Marine pharmacology in 2014-2015: marine compounds with antidiabetic and anti-inflammatory activity, and affecting the immune and nervous system.

\begin{tabular}{|c|c|c|c|c|c|c|c|}
\hline Drug Class & Compound/Organism $^{\text {a+ }}$ & Chemistry & Pharmacological Activity & $\mathrm{IC}_{50} \mathrm{~b}$ & MMOA $^{\mathrm{c}}$ & Country ${ }^{d}$ & References \\
\hline Antidiabetic & $\begin{array}{l}\text { fucoxanthin and fucoxanthinol (134, } \\
\text { 135)/alga }\end{array}$ & Terpenoid $^{\mathrm{f}}$ & $\begin{array}{l}\text { Improved glucose tolerance in vitro and } \\
\text { in vivo }\end{array}$ & $50 \mu \mathrm{M} *$ & Cytokine inhibition & JPN, S. KOR & {$[154,155]$} \\
\hline Antidiabetic & octaphlorethol A (136)/alga & Shikimate $^{\mathrm{h}}$ & $\alpha$-glucosidase inhibition & $110 \mu \mathrm{M}$ & $\begin{array}{l}\text { Molecular docking on active } \\
\text { site }\end{array}$ & CAN, S. KOR & [156] \\
\hline Antidiabetic & phlorofucofuroeckol-A (10)/alga & Polyketide $^{\mathrm{d}}$ & Decreased glucose levels in vivo & $10 \mathrm{mg} / \mathrm{kg} * *$ & $\alpha$-glucosidase inhibition & S. KOR & [157] \\
\hline Antidiabetic & Con-Ins G1 (137)/cone snail & Peptide $\mathrm{g}$ & Hypoglycemia induction & $65 \mathrm{ng} / \mathrm{g}$ * & Undetermined & AUS, DNK, USA & [158] \\
\hline Antidiabetic & dehydroeuryspongin A (138)/sponge & Terpenoid $^{\mathrm{f}}$ & PTP1B inhibition & $3.58 \mu \mathrm{M}$ & Undetermined & IDN, JPN & [159] \\
\hline Antidiabetic & Epicoccum sp. diterpene (139)/fungus & Terpenoid $^{f}$ & $\alpha$-glucosidase inhibition & $4.6 \mu \mathrm{M}$ & Undetermined & $\mathrm{CHN}$ & [160] \\
\hline Antidiabetic & suncheonoside A (140)/bacterium & Terpenoid $^{\mathrm{f}}$ & Adiponectin production & $10 \mu \mathrm{M} *$ & Undetermined & S. KOR & [161] \\
\hline Antidiabetic & terrelumamide $\mathrm{A}(\mathbf{1 4 1}) /$ fungus & Peptide ${ }^{g}$ & Adiponectin production & $37 \mu \mathrm{M}^{*}$ & Undetermined & S. KOR & [162] \\
\hline Antidiabetic & X. testudinaria lipid (142)/sponge & Polyketide $^{\mathrm{d}}$ & PTP1B inhibition & $5.3 \mu \mathrm{M}$ & Undetermined & $\mathrm{CHN}$ & [163] \\
\hline Anti-inflammatory & $\begin{array}{l}\text { alcyonolide congeners }(143,144) / \text { soft } \\
\text { coral }\end{array}$ & Terpenoid $^{\mathrm{f}}$ & Macrophage NO inhibition & $2 \mu \mathrm{M}^{*}$ & iNOS expression inhibition & JPN & {$[164]$} \\
\hline Anti-inflammatory & astaxanthin (145)/alga & Terpenoid $^{\mathrm{f}}$ & Oxidative stress inhibition in vivo & $10 \mathrm{mg} / \mathrm{kg} * *$ & CAT and SOD enhancement & $\mathrm{CHN}$ & [165] \\
\hline Anti-inflammatory & 8,8'-bieckol (146)/alga & Polyketide $^{\text {e }}$ & $\begin{array}{l}\text { Macrophage } \mathrm{NO} \text { and } \mathrm{PGE}_{2} \text { release } \\
\text { inhibition }\end{array}$ & $50 \mu \mathrm{M}^{*}$ & Inhibition of $\mathrm{NF} \kappa \mathrm{B}$ & S. KOR & {$[166]$} \\
\hline Anti-inflammatory & convolutamydine A (147)/ bryozoa & Alkaloid $\mathrm{g}$ & $\begin{array}{l}\text { Formalin-induced licking behavior } \\
\text { inhibition }\end{array}$ & $0.01 \mathrm{mg} / \mathrm{kg}$ & TNF- $\alpha$, IL-6 release inhibition & BRA & [167] \\
\hline Anti-inflammatory & capgermacrene A (148)/ soft coral & Terpenoid $^{\mathrm{f}}$ & Macrophage NO and IL-1 $\beta$ inhibition & ${ }_{*}^{<10 \mu \mathrm{g} / \mathrm{mL}}$ & iNOS expression inhibition & MYS, S. KOR & [168] \\
\hline Anti-inflammatory & cathelicidin (4)/sea snake & Peptide $\mathrm{g}$ & Binding of LPS to TLR4 inhibition & $4 \mu \mathrm{g} / \mathrm{mL}^{*}$ & $\begin{array}{l}\text { Inflammatory cytokine } \\
\text { inhibition }\end{array}$ & $\mathrm{CHN}$ & [26] \\
\hline Anti-inflammatory & $\begin{array}{l}\text { dactyloditerpenol acetate (149)/ sea } \\
\text { hare }\end{array}$ & Terpenoid $^{f}$ & LPS- activated microglia in vitro inhibition & $0.4-1 \mu \mathrm{M}$ & $\mathrm{O}_{2}^{-}$and $\mathrm{TXB}_{2}$ inhibition & USA & [169] \\
\hline Anti-inflammatory & dieckol (150)/alga & Shikimate $^{\mathrm{h}}$ & Macrophage iNOS transcription inhibition & $30 \mu \mathrm{M} *$ & $\begin{array}{l}\text { Inhibition of NFKB and } \\
\text { p38MAPK }\end{array}$ & S. KOR & [170] \\
\hline Anti-inflammatory & dieckol (150)/alga & Shikimate ${ }^{\mathrm{h}}$ & $\begin{array}{l}\text { Human keratinocyte MDC/CCL22 } \\
\text { inhibition }\end{array}$ & $12.5 \mu \mathrm{M} *$ & $\begin{array}{l}\text { STAT1 phosphorylation } \\
\text { inhibition }\end{array}$ & S. KOR & [171] \\
\hline Anti-inflammatory & excavatolide B (151)/gorgonian & Terpenoid $^{\mathrm{f}}$ & $\begin{array}{l}\text { Macrophage iNOS and COX-2 } \\
\text { transcription inhibition }\end{array}$ & $25 \mu \mathrm{M}^{*}$ & $\begin{array}{l}\text { In vivo iNOS protein } \\
\text { expression reduction }\end{array}$ & TWN & [172] \\
\hline Anti-inflammatory & flexibilide (152)/soft coral & Terpenoid $^{\mathrm{f}}$ & Neuropathic pain inhibition & $10 \mu \mathrm{g} *$ & Upregulation of TGF- $\beta 1$ & TWN & [173] \\
\hline Anti-inflammatory & fucoxanthinol (135)/alga & Terpenoid ${ }^{f}$ & $\begin{array}{l}\text { Macrophage TNF- } \alpha \text { and MCP- } 1 \text { release } \\
\text { inhibition }\end{array}$ & $10 \mu \mathrm{M}$ & COX-2 expression inhibition & JPN & [155] \\
\hline Anti-inflammatory & H. fusiforme flavone (153)/ alga & $\begin{array}{l}\text { Shikimate } \\
\text { h/Polyketide } \mathrm{d}\end{array}$ & $\begin{array}{l}\text { Macrophage } \mathrm{NO} \text { and } \mathrm{PGE}_{2} \text { release } \\
\text { inhibition }\end{array}$ & $10 \mu \mathrm{g} / \mathrm{mL}^{*}$ & $\begin{array}{l}\text { iNOS, COX-2 expression } \\
\text { inhibition }\end{array}$ & S. KOR & [174] \\
\hline Anti-inflammatory & 5ß-hydroxypalisadin B (154)/alga & Terpenoid ${ }^{\mathrm{f}}$ & Macrophage NO release inhibition & $17 \mu \mathrm{M}$ & $\begin{array}{l}\text { Partial iNOS expression } \\
\text { inhibition }\end{array}$ & LKA, MYS, S. KOR & [175] \\
\hline Anti-inflammatory & $\begin{array}{l}\text { glaucumolides A and B (155, } \\
\text { 156)/soft coral }\end{array}$ & Terpenoid $^{\mathrm{f}}$ & Neutrophil SOX and elastase inhibition & $2.8-4 \mu \mathrm{M}^{*}$ & iNOS, COX-2 inhibition & TWN & [176] \\
\hline Anti-inflammatory & phlorofucofuroeckol-B (157)/alga & Polyketide $^{\mathrm{d}}$ & Microglia activation inhibition & $0.1 \mu \mathrm{g} / \mathrm{mL}^{*}$ & iNOS, COX-2 inhibition & S. KOR & [177] \\
\hline
\end{tabular}


Table 2. Cont.

\begin{tabular}{|c|c|c|c|c|c|c|c|}
\hline Drug Class & Compound/Organism $^{\text {a+ }}$ & Chemistry & Pharmacological Activity & $\mathrm{IC}_{50} \mathrm{~b}$ & MMOA $^{\mathrm{c}}$ & Country $^{d}$ & References \\
\hline Anti-inflammatory & P. palmata lipid (158)/alga & Polyketide ${ }^{d}$ & Macrophage NO release inhibition & $16.7 \mu \mathrm{M}$ & iNOS expression inhibition & CAN & [178] \\
\hline Anti-inflammatory & reduced scytonemin (159)/alga & Alkaloid $\mathrm{g}$ & Macrophage NO release inhibition & $1 \mu \mathrm{M}^{*}$ & HO-1 expression induction & JPN & [179] \\
\hline Anti-inflammatory & sinuleptolide (160)/soft coral & Terpenoid $^{\mathrm{f}}$ & $\begin{array}{l}\text { LPS-activated rat microglia in vitro } \\
\text { inhibition }\end{array}$ & $0.5-2.9 \mu \mathrm{M}$ & Cytokine release inhibition & $\begin{array}{l}\text { ESP, FIN, IND, } \\
\text { ITA, }\end{array}$ & [180] \\
\hline Anti-inflammatory & sarcopanol A (161)/soft coral & Terpenoid $^{\mathrm{f}}$ & $\begin{array}{l}\text { iNOS, COX-2, and ICAM-1 transcription } \\
\text { inhibition }\end{array}$ & $8.3 \mu \mathrm{M}$ & NFkB inhibition & S. KOR, VNM & [181] \\
\hline Anti-inflammatory & sinumaximol $\mathrm{H}(\mathbf{1 6 2}) /$ sponge & Terpenoid ${ }^{f}$ & iNOS and ICAM-1 transcription inhibition & $1 \mu \mathrm{M} *$ & NFKB inhibition & S. KOR, VNM & [182] \\
\hline Anti-inflammatory & tanzawaic acid A (163)/fungus & Polyketide ${ }^{\mathrm{d}}$ & NO inhibition & $7.1 \mu \mathrm{M}$ & iNOS and PTP1B inhibition & VNM, S. KOR & [183] \\
\hline Anti-inflammatory & aspertetranone $\mathrm{D}(\mathbf{1 6 4}) /$ fungus & Terpenoid $^{\mathrm{f}}$ & IL-6 inhibition & $40 \mu \mathrm{M} *$ & Undetermined & CHN, USA & [184] \\
\hline Anti-inflammatory & briarenolide J (165)/soft coral & Terpenoid $\mathrm{f}$ & Neutrophil SOX and elastase inhibition & $10-15 \mu \mathrm{M}$ & Undetermined & TWN & [185] \\
\hline Anti-inflammatory & $\begin{array}{l}\text { briarenolides K and L }(166,167) / \text { soft } \\
\text { coral }\end{array}$ & Terpenoid $^{\mathrm{f}}$ & Macrophage iNOS inhibition & $\underset{*}{>10 \mu \mathrm{g} / \mathrm{mL}}$ & Undetermined & TWN & [186] \\
\hline Anti-inflammatory & $\begin{array}{l}\text { briarenolides U, V, W }(168,169) / \text { soft } \\
\text { coral }\end{array}$ & Terpenoid $^{f}$ & $\begin{array}{l}\text { Macrophage COX-2 and iNOS expression } \\
\text { inhibition }\end{array}$ & $\begin{array}{l}>10 \mu \mathrm{g} / \mathrm{mL} \\
*\end{array}$ & Undetermined & TWN & [187] \\
\hline Anti-inflammatory & $\begin{array}{l}\text { briaviolides E and I (170, 171)/soft } \\
\text { coral }\end{array}$ & Terpenoid $^{f}$ & Neutrophil SOX and elastase inhibition & $\begin{array}{l}>10 \mu \mathrm{g} / \mathrm{mL} \\
*\end{array}$ & Undetermined & TWN & [188] \\
\hline Anti-inflammatory & dermacozine H (172)/bacterium & Alkaloid $\mathrm{g}$ & Radical scavenging activity & $18.8 \mu \mathrm{M}$ & Undetermined & DEU, EGY, UK & [189] \\
\hline Anti-inflammatory & dysifragilone A (173)/sponge & Terpenoid $^{\mathrm{f}}$ & Macrophage NO release inhibition & $6.6 \mu \mathrm{M}$ & Undetermined & $\mathrm{CHN}$ & [190] \\
\hline Anti-inflammatory & D. plectens xenicane (174)/alga & Terpenoid $^{\mathrm{f}}$ & Macrophage NO release inhibition & $10 \mu \mathrm{M}$ & Undetermined & $\mathrm{CHN}$ & [191] \\
\hline Anti-inflammatory & comaparvin (175)/crinoid & Polyketide $^{\mathrm{d}}$ & $\begin{array}{l}\text { Carrageenan-induced hyperalgesia } \\
\text { inhibition }\end{array}$ & $30 \mathrm{mg} / \mathrm{kg}$ * & iNOS expression inhibition & TWN & [192] \\
\hline Anti-inflammatory & $\begin{array}{l}\text { hirsutalins } N \text { and } S(\mathbf{1 7 6}, \mathbf{1 7 7}) / \text { soft } \\
\text { coral }\end{array}$ & Terpenoid $^{\mathrm{f}}$ & Neutrophil elastase inhibition & $10 \mu \mathrm{M}^{*}$ & Undetermined & TWN & {$[193,194]$} \\
\hline Anti-inflammatory & hirsutocospiro A (178)/soft coral & Terpenoid $^{f}$ & Neutrophil SOX and elastase inhibition & $3.7-4.1 \mu \mathrm{M}$ & Undetermined & TWN & [195] \\
\hline Anti-inflammatory & isosinulaflexiolide K (179)/soft coral & Terpenoid ${ }^{f}$ & $\begin{array}{l}\text { Macrophage COX-2 and iNOS expression } \\
\text { inhibition }\end{array}$ & $>10 \mu \mathrm{M}^{*}$ & Undetermined & TWN & [196] \\
\hline Anti-inflammatory & klyflaccisteroid F (180)/soft coral & Terpenoid $^{\mathrm{f}}$ & Neutrophil SOX and elastase inhibition & $0.34 \mu \mathrm{M}$ & Undetermined & TWN & [197] \\
\hline Anti-inflammatory & krempfielin N (181)/soft coral & Terpenoid $^{\mathrm{f}}$ & Neutrophil SOX and elastase inhibition & $>10 \mu \mathrm{M} *$ & Undetermined & TWN & [198] \\
\hline Anti-inflammatory & $\begin{array}{l}\text { krempfielins Q and R }(\mathbf{1 8 2}, \mathbf{1 8 3}) / \text { soft } \\
\text { coral }\end{array}$ & Terpenoid $^{\mathrm{f}}$ & Neutrophil SOX and elastase inhibition & $>10 \mu \mathrm{M} *$ & Undetermined & TWN & [199] \\
\hline Anti-inflammatory & methylfarnesylquinone (184)/alga & $\begin{array}{l}\text { Shikimate } \\
\text { h/Terpenoid }{ }^{f}\end{array}$ & Neutrophil SOX and elastase inhibition & $\begin{array}{l}0.2-0.48 \\
\mu \mathrm{g} / \mathrm{mL}\end{array}$ & Undetermined & TWN & [200] \\
\hline Anti-inflammatory & monanchosterol B (185)/sponge & Terpenoid $^{\mathrm{f}}$ & Macrophage IL-6 expression inhibition & $5 \mu \mathrm{M}$ & Undetermined & S. KOR & [201] \\
\hline Anti-inflammatory & P. nodosus sterol (186)/starfish & Terpenoid $^{f}$ & IL-12 and IL-6 inhibition & $1.3-3.1 \mu \mathrm{M}$ & Undetermined & VNM, S. KOR & [202] \\
\hline Anti-inflammatory & rhytidenone C (187)/fungus & Polyketide $^{\mathrm{d}}$ & Macrophage NO inhibition & $0.31 \mu \mathrm{M}$ & Undetermined & THA & [203] \\
\hline Anti-inflammatory & sarcocrassocolide E (188)/soft coral & Terpenoid $^{f}$ & $\begin{array}{l}\text { Macrophage COX-2 and iNOS expression } \\
\text { inhibition }\end{array}$ & $<10 \mu \mathrm{M}^{*}$ & Undetermined & TWN & [204] \\
\hline Anti-inflammatory & sinulacembranolide A (189)/octocoral & Terpenoid $^{f}$ & Macrophage iNOS expression inhibition & $<10 \mu \mathrm{M}$ & Undetermined & TWN & [205] \\
\hline
\end{tabular}


Table 2. Cont.

\begin{tabular}{|c|c|c|c|c|c|c|c|}
\hline Drug Class & Compound/Organism ${ }^{\text {a+ }}$ & Chemistry & Pharmacological Activity & $\mathrm{IC}_{50} \mathrm{~b}$ & MMOA $^{\mathrm{c}}$ & Country ${ }^{d}$ & References \\
\hline Anti-inflammatory & thomimarine $B(\mathbf{1 9 0}) /$ fungus & Terpenoid $^{\mathrm{f}}$ & Macrophage NO inhibition & $>10 \mu \mathrm{M}$ & Undetermined & RUS, VNM & [206] \\
\hline Anti-inflammatory & tortuosene A (191)/soft coral & Terpenoid $^{\mathrm{f}}$ & Neutrophil SOX inhibition & $7.3 \mu \mathrm{M}$ & Undetermined & TWN & [207] \\
\hline Immune system & $\begin{array}{l}\text { grassypeptolide A } \\
\text { (192)/cyanobacterium }\end{array}$ & Peptide $\mathrm{g}$ & IL-2 and T-cell proliferation inhibition & $1 \mu \mathrm{M} *$ & $\begin{array}{l}\text { Dipeptidyl peptidase } 8 \\
\text { inhibition }\end{array}$ & CHN, JPN, USA & [208] \\
\hline Immune system & F. reticulata alkaloids (193)/sponge & Alkaloid $\mathrm{g}$ & IL-2 inhibition & $5-50 \mu \mathrm{M}$ * & Undetermined & CHN, NLD & [209] \\
\hline Immune system & luzonicoside A (194)/starfish & Terpenoid $^{\mathrm{f}}$ & Macrophage NO and ROS stimulation & $\begin{array}{l}0.01-0.1 \\
\mu \mathrm{M} *\end{array}$ & Undetermined & RUS, VNM & [210] \\
\hline Immune system & typicoside $C 1(195) /$ sea cucumber & Terpenoid ${ }^{f}$ & Macrophage ROS stimulation & $<1 \mathrm{ng} / \mathrm{mL}^{*}$ & Undetermined & IND, RUS & [211] \\
\hline Nervous system & aurone glycoside (196)/fungus & $\begin{array}{l}\text { Shikimate } \\
\text { h/Polyketide }{ }^{d}\end{array}$ & Oxidative stress neuroprotection & $1 \mu \mathrm{M} *$ & Apoptosis inhibition & CHN & [212] \\
\hline Nervous system & azaspiracid-1 (197)/alga & $\begin{array}{l}\text { Polyketide }{ }^{\mathrm{d}} / \\
\text { Alkaloid } \mathrm{g}\end{array}$ & Peripherin-labelled neurite process & $15 \mathrm{nM} *$ & $\begin{array}{l}\text { Peripherin isoform } \\
\text { downregulation }\end{array}$ & NOR & [213] \\
\hline Nervous system & caulerpine (198)/alga & Alkaloid g & Antinociceptive activity & $40 \mathrm{mg} / \mathrm{kg}$ * & $\begin{array}{l}\text { Involves } \alpha 2 \text { and } 5-\mathrm{HT}_{3} \\
\text { receptors }\end{array}$ & BRA & [214] \\
\hline Nervous systema & 6-bromohypaphorine (199)/sea slug & Alkaloid $\mathrm{g}$ & Human $\alpha 7 \mathrm{nAChR}$ agonist & $23 \mu \mathrm{M}$ & Rise $\left[\mathrm{Ca}^{2+}\right] \mathrm{i}$ & RUS & [215] \\
\hline Nervous system & piscidin (200)/fish & Peptide $\mathrm{g}$ & Antinociceptive activity & $20 \mu \mathrm{g} / \mathrm{rat}$ * & Phosphor-mTOR inhibition & TWN & [216] \\
\hline Nervous system & $\begin{array}{l}\text { C. marmoreus conotoxin Mr1.7 } \\
\text { (201)/cone snail }\end{array}$ & Peptide $\mathrm{g}$ & Ach-evoked membrane current inhibition & $53.1 \mathrm{nM}$ & $\mathrm{A} 3 \beta 2 \mathrm{nAChR}$ inhibition & $\mathrm{CHN}$ & [217] \\
\hline Nervous system & $\begin{array}{l}\text { C. litteratus conotoxin lt16a (202)/cone } \\
\text { snail }\end{array}$ & Peptide $\mathrm{g}$ & Neuronal $\mathrm{Na}^{+}$current inhibition & $1 \mu \mathrm{M} *$ & Undetermined & $\mathrm{CHN}$ & [218] \\
\hline Nervous system & C. vitulinus peptide (203)/ cone snail & Peptide $\mathrm{g}$ & Neuronal BK channel inhibition & $8.5 \mu \mathrm{M}$ & $\begin{array}{l}\text { Electrostatic interaction with } \\
\beta 4 \text { subunits }\end{array}$ & CHN, USA & [219] \\
\hline Nervous system & echinochrome A (204)/sea urchin & Polyketide $^{\mathrm{d}}$ & $\begin{array}{l}\text { Acetylcholinesterase inhibition and } \mathrm{NO} \\
\text { scavenging }\end{array}$ & $16.4 \mu \mathrm{M}$ & $\begin{array}{l}\text { Irreversible and } \\
\text { uncompetitive inhibition }\end{array}$ & S. KOR, RUS & [220] \\
\hline Nervous system & ganglioside LLG-3 (205)/starfish & Glycolipid & Neuritogenesis stimulation in vitro & $1 \mathrm{nM} *$ & MAPK signaling stimulation & JPN & [221] \\
\hline Nervous system & heteronemin (206)/sponge & Terpenoid $^{\mathrm{f}}$ & TDP-43 binding to DNA inhibition & $10.1 \mathrm{nM}$ & $\begin{array}{l}\text { Promoted aggregation of } \\
\text { insoluble TDP-43 }\end{array}$ & ITA & [222] \\
\hline Nervous system & pinnatoxin A (207)/mollusc & $\begin{array}{l}\text { Polyketide } \mathrm{d} / \\
\text { Alkaloid } \mathrm{g}\end{array}$ & $\begin{array}{l}\text { Muscle and neuronal nAChRs receptor } \\
\text { inhibition }\end{array}$ & $\begin{array}{l}0.086-47.5 \\
\mathrm{nM}\end{array}$ & $\begin{array}{l}\text { EF-ketal ring confers nAChR } \\
\text { subtype specificity }\end{array}$ & FRA, USA & [223] \\
\hline Nervous tissue & PhcrTx1 (208)/sea anemone & Peptide $\mathrm{g}$ & ASIC inhibition & $100 \mathrm{nM}$ & $\begin{array}{l}\text { Lower potency on } \mathrm{Kv} \\
\text { channels }\end{array}$ & $\begin{array}{l}\text { BEL, BRA, CUB, } \\
\text { DEU, ESP, MEX }\end{array}$ & [224] \\
\hline Nervous tissue & phlorofucofuroeckol-A (10)/alga & Polyketide ${ }^{\mathrm{d}}$ & Butyrylcholinesterase inhibition & $0.95 \mu \mathrm{M}$ & $\beta$-secretase inhibition & S. KOR & [225] \\
\hline Nervous tissue & S. auritum ceramide $(209) /$ soft coral & Polyketide $^{\mathrm{d}}$ & $\begin{array}{l}\text { Anxiolytic and CNS depressing activity } \\
\text { in vivo }\end{array}$ & $1 \mathrm{mg} / \mathrm{kg} * *$ & $\begin{array}{l}\text { GABA(A) receptor } \\
\text { modulation }\end{array}$ & EGY, USA & [226] \\
\hline Nervous system & spirolide C (210)/dinoflagellate & $\begin{array}{l}\text { Polyketide } \mathrm{d} / \\
\text { Alkaloid } \mathrm{g}\end{array}$ & nAChR inhibition & $1.5-3 \mathrm{nM}^{*}$ & $\begin{array}{l}\text { Muscle and neuronal -type } \\
\text { nAChR inhibition }\end{array}$ & FRA & [227] \\
\hline Nervous system & zonarol (211)/alga & $\underset{\mathrm{f}}{\text { Meroterpenoid }}$ & Glutamate toxicity inhibition in vitro & $0.22 \mu \mathrm{M}$ & Nrf2/ARE pathway activation & JPN, USA & [228] \\
\hline
\end{tabular}


Table 2. Cont.

\begin{tabular}{|c|c|c|c|c|c|c|c|}
\hline Drug Class & Compound/Organism $^{\text {a+ }}$ & Chemistry & Pharmacological Activity & $\mathrm{IC}_{50} \mathrm{~b}$ & MMOA $^{\mathrm{c}}$ & Country ${ }^{d}$ & References \\
\hline Nervous system & aplysinellamide-1 (212)/sponge & Alkaloid $\mathrm{g}$ & ApoE secretion modulation & $30 \mu \mathrm{M} *$ & Undetermined & AUS, CAN & [229] \\
\hline Nervous system & A. terreus lactones $(\mathbf{1 2 0}, \mathbf{1 2 1}) /$ fungus & Polyketide $^{\mathrm{d}}$ & acetylcholinesterase inhibition & $4.2 \mu \mathrm{M}$ & Undetermined & $\mathrm{CHN}$ & {$[115]$} \\
\hline Nervous system & $\begin{array}{l}\text { C. araneosus ar3j conotoxin (213)/cone } \\
\text { snail }\end{array}$ & Peptide $\mathrm{g}$ & Sleep induction & $2 \mathrm{nM}^{*}$ & Undetermined & IND & [230] \\
\hline Nervous system & D. cejpii steroid (214)/fungus & Terpenoid $^{f}$ & Amyloid $\beta-42$ production inhibition & $10 \mu \mathrm{M}^{*}$ & Undetermined & DEU, FRA & [231] \\
\hline Nervous system & genuanine (215)/cone snail & Alkaloid $\mathrm{g}$ & Paralysis in vivo & $40 \mathrm{nM}^{*}$ & Undetermined & PRT, USA & [232] \\
\hline Nervous system & homoaerothionin (216)/sponge & Alkaloid $\mathrm{g}$ & acetylcholinesterase inhibition & $2.9-6.2 \mu \mathrm{M}$ & Undetermined & THA & [233] \\
\hline Nervous system & mooreamide A (217)/bacterium & Polyketide $^{\mathrm{d}}$ & $\mathrm{CB}_{1}$ binding & $0.47 \mu \mathrm{M} * *$ & Undetermined & ITA, PNG, USA & [234] \\
\hline Nervous system & $\begin{array}{l}\text { S. spinosulus hydroquinone } \\
(\mathbf{2 1 8}) / \text { sponge }\end{array}$ & $\begin{array}{l}\text { Shikimate } \\
\text { h/Polyketide }\end{array}$ & Enhance glutamate and ACh release & $10 \mu \mathrm{M}^{*}$ & Undetermined & ITA & [235] \\
\hline
\end{tabular}

a Organism: Kingdom Animalia: fish (Phylum Chordata); bryozoan; coral and sea anemone (Phylum Cnidaria); crinoid, sea urchin, starfish (Phylum Echinodermata); cone snail, sea slug

(Phylum Mollusca); sponge (Phylum Porifera); Kingdom Fungi: fungus; Kingdom Plantae: alga; Kingdom Monera: bacterium; Kingdom Protozoa: dinoflagellates; ${ }^{\text {I IC }}$ 50: concentration of a

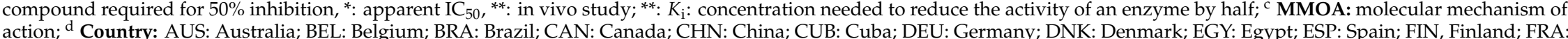
France; IDN: Indonesia; IND, India; ITA: Italy; JPN: Japan; LKA: Sri Lanka; MEX: Mexico; MYS: Malaysia; NLD: Netherlands; NOR: Norway; PNG: Papua New Guinea; PRT: Portugal;

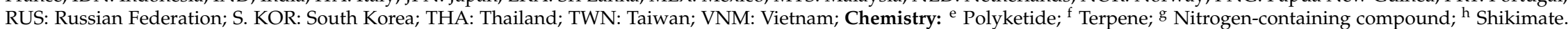
Abbreviations: Ach: acetylcholine; ApoE: apolipoprotein E; ASIC: acid-sensing sodium ion channel; $C A T$ : catalase; $\mathrm{CB}_{1}$ : cannabinoid receptor 1; $\mathrm{CNS}_{\mathrm{N}}$ : central nervous system; $\mathrm{COX}$ : Abbreviations: Ach: acetylcholine; ApoE: apolipoprotein E; ASIC: acid-sensing sodium ion channel; CAT: catalase; $\mathrm{CB}_{1}$ : cannabinoid receptor 1; $\mathrm{CNS}_{\mathrm{i}}$ : central nervous system; $\mathrm{COX}$ : cyclooxygenase; HO-1: heme oxygenase-1; ICAM: intercellular adhesion molecule- 1 ; IL: interleukin; iNOS: inducible nitric oxide synthase; Kv current: voltage-gated K+ current; MAPK:
mitogen-activated protein kinase pathway; MDC/CCL22: macrophage-derived chemokine, C-C motif chemokine 22; nAChR: nicotinic acetylcholine receptor; NA: not available; NF- $k B$ : mitogen-activated protein kinase pathway; MDC/CCL22: macrophage-derived chemokine, C-C motif chemokine 22; nAChR: nicotinic acetylcholine receptor; NA: not available; NF-KB:
nuclear factor kappa-light-chain-enhancer of activated B cells; NO: nitric oxide; nAChR: nicotinic acetylcholine receptor; Nrf2-ARE: nuclear transcription factor E2-related factor antioxidant response element; PTP1B: tyrosine protein; phosphatase 1B; ROS: reactive oxygen species; SOD: superoxide dismutase; SOX: superoxide; STAT1: signal transducer and activator of transcription1; TDP-43: trans-activation response DNA-binding protein of $43 \mathrm{kDa}$ 


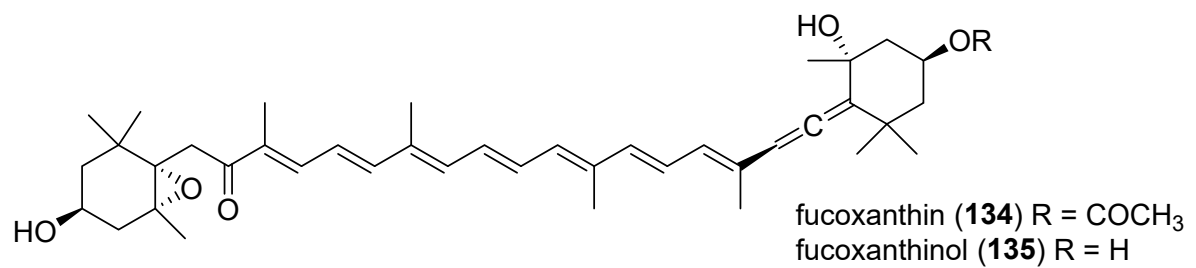<smiles>CCCCOc1cc(O)c(Oc2cc(O)c(Oc3cc(O)c(Oc4cc(O)cc(O)c4)c(O)c3)c(O)c2)c(O)c1Oc1cc(O)c(Oc2cc(O)c(Oc3c(O)cc(O)cc3O)c(O)c2)c(O)c1</smiles>

\section{GVVEHCCHRPCSNAEFKKYC}

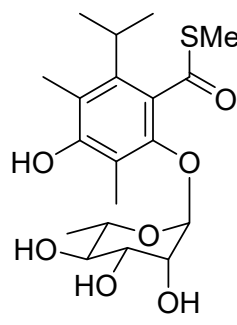

suncheonoside A (140)

Con-Ins G1 (137)<smiles>CC1=CC23CC(C)(C)CC2c2occc2C=C13</smiles>

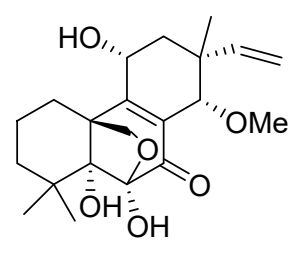

dehydroeuryspongin $A$ (138)

Epicoccum sp. diterpene (139)<smiles>COC(=O)c1ccccc1NC(=O)[C@@H](NC(=O)c1cnc2c(n1)c(=O)[nH]c(=O)n2C)[C@H](O)[C@@H](C)O</smiles><smiles>C=C(CCCC(C)=O)C1(C(C)=O)C(C=O)OC=C2C(CC=C(C)C)OC(=O)CC21</smiles><smiles></smiles>

alcyonolide congener 143 alcyonolide congener 144<smiles>C=CC(=CC)Oc1c(O)cc(O)c2c1Oc1c(cc(O)c(-c3c(O)cc4c(c3O)Oc3c(O)cc(O)c(Oc5cc(O)cc(O)c5)c3O4)c1O)O2</smiles>
$\overbrace{\mathrm{OH}}$ 8,8'-bieckol (146)<smiles>CC1=C(/C=C/C(C)=C/C=C/C=C(C)/C=C/C=C(C)/C=C/C=C(C)/C=C/C2=C(C)C(=O)C(O)CC2(C)C)C(C)(C)CC(O)C1=O</smiles>

Figure 2. Cont. 
<smiles>CC(=O)CC1(O)C(=O)Nc2cc(Br)cc(Br)c21</smiles>

convolutamydine A (147)<smiles>CC1=CCC(C(C)(C)C)CC(=O)C(C)=C1</smiles>

capgermacrene A (148)<smiles>CC(=O)OC(CCC(C)C1CCC(C)=CC1O)C(C)(O)CCC=C(C)C</smiles>

dactyloditerpenol acetate (149)<smiles>Oc1cc(O)cc(Oc2c(O)cc(O)c3c2Oc2c(O)cc(O)cc2O3)c1</smiles>

dieckol (150)<smiles>COc1ccc(-c2oc3c(OC)c(OC)c(OC)c(O)c3c(=O)c2OC)cc1OC</smiles>

Hizikia fusiforme flavone 153

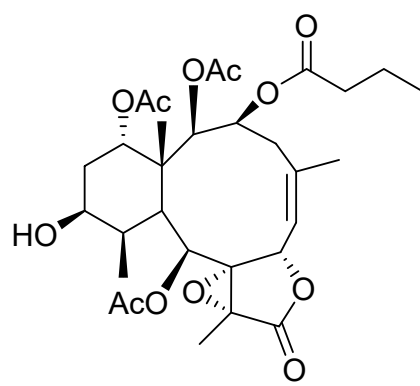

excavatolide B (151)<smiles>CC1(C)C(Br)CCC(O)C1C1(C)O[C@@H](CBr)C=C[C@H]1Br</smiles>

5 $\beta$-hydroxypalisadin B (154)

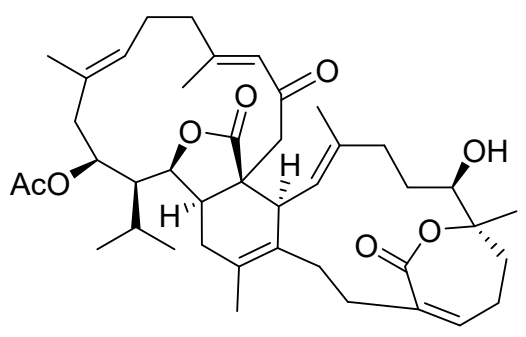

glaucumolide A (155)

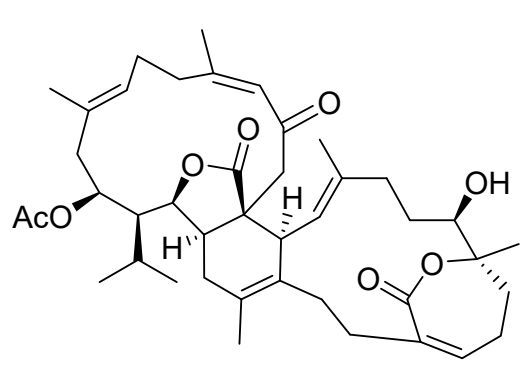

glaucumolide B (156)<smiles>CC(C)(C)Oc1cc(O)c(O)c2c1-c1c(O)cc(O)c(Oc3cc(O)cc(O)c3)c1Oc1c(O)c(O)cc(O)c1-2</smiles><smiles>CC/C=C\C/C=C\C/C=C\C/C=C\C/C=C\CCCC(=O)OCC(COP(=O)(O)OCC(O)CO)OC(=O)C/C=C/CCCCCCCCCC</smiles>

Palmaria palmata lipid 158

Figure 2. Cont. 
<smiles>O=C1/C(=C2\C(=O)c3c([nH]c4ccccc34)\C2=C/c2ccc(O)cc2)c2[nH]c3ccccc3c2/C1=C\c1ccc(O)cc1</smiles>

reduced scytonemin (159)<smiles>CC1=C[C@H]2OC(=O)C(C)=C2CC[C@](C)(O)/C=C/C[C@](C)(O)[C@@H](O)CC1</smiles>

sinumaximol H (162)

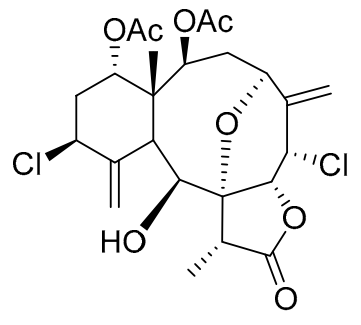

briarenolide J (165)

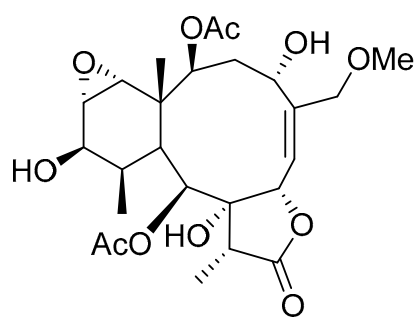

briarenolide U (168)<smiles>C=C(C)[C@H]1CC(=O)C[C@H]2O[C@@](C)(CC2=O)C[C@@H]2OC(=O)/C(=C\C[C@@H]1C)[C@H]2O</smiles>

sinuleptolide (160)<smiles>Cc1ccc2c(c1/C=C/C=C/C(=O)O)[C@H](C)C[C@@H](C)C2</smiles>

tanzawaic acid A (163)

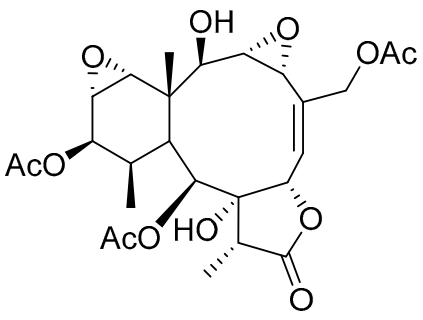

briarenolide K (166)<smiles>CC(=O)OC(C)(C)C/C=C/[C@H](C)[C@H]1CC[C@H]2[C@@H]3C[C@H](O)[C@@]4(O)C[C@@H](O)C[C@H](O)[C@@]4(C)[C@H]3CC[C@@]21C</smiles>

sarcopanol A (161)

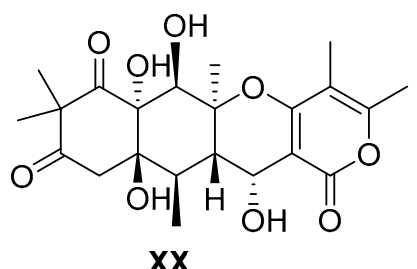

aspertetranone $D(164)$

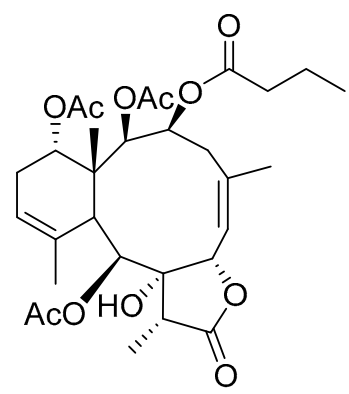

briarenolide L (167)

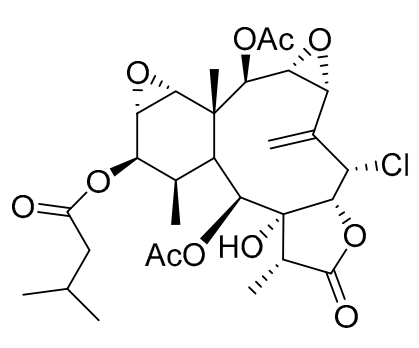

braviolide E (170)

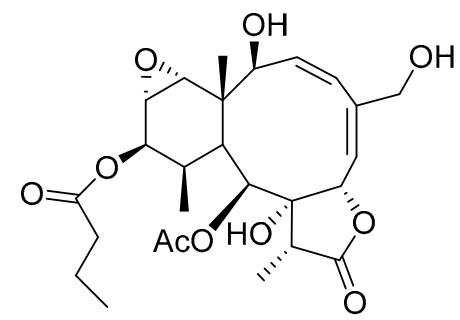

briarenolide $\mathrm{V}(168)$

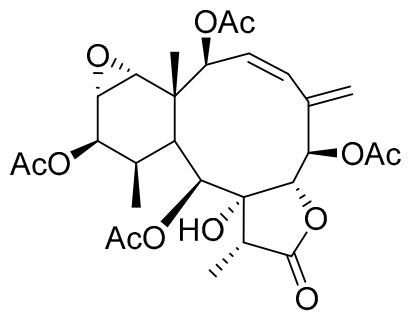

briarenolide W (169)

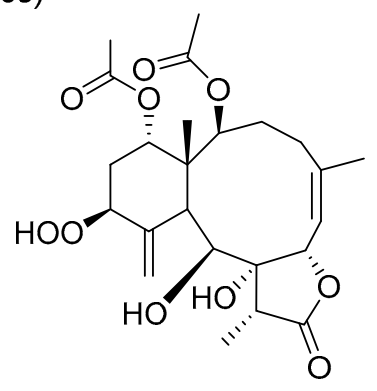

braviolide I (171)

Figure 2. Cont. 
<smiles>CC(=O)c1cc(C=O)cc2c1Nc1cccc(C(N)=O)c1N2C</smiles>

dermacozine $\mathrm{H}$ (172)<smiles>CCCc1cc(=O)c2c(O)cc3cc(O)cc(OC)c3c2o1</smiles><smiles>COC(=O)CCCC1(C)CCC2(OC1=O)C(=O)C(C)=C(C)C2(C)C(C)=O</smiles>

hirsutocospiro A (178)

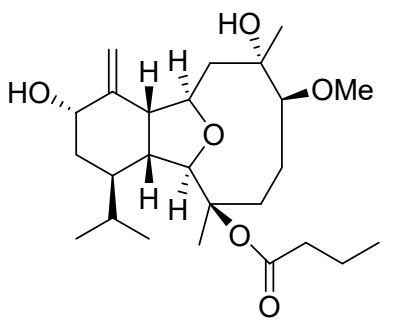

krempfielin N (181)<smiles>CNC1=CC(=O)C2=C(C1=O)C1(C)CCC3(C)C(C)=CCCC3[C@@H]1C2</smiles>

dysifragilone A (173)

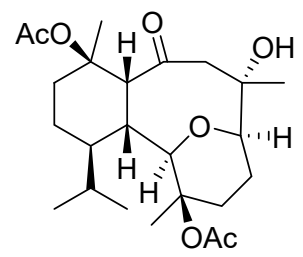

hirsutalin $\mathrm{N}$ (176)

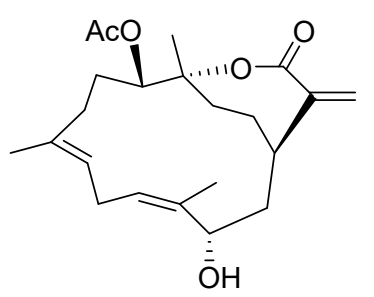

isosinulaflexiolide $\mathrm{K}$ (179)

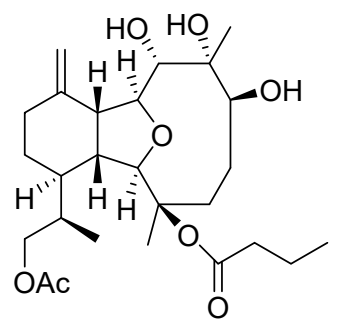

krempfielin Q (182)<smiles>CC(C)=CCC[C@]1(C)C2=C(CC[C@H](C)[C@@H](C)C[C@@H]1O)COC2=O</smiles>

Dictyota plectens xenicane 174<smiles>C=C1CC2O[C@@H](C(C)OC(=O)C(CC)OC(C)=O)C(C)(OC1=O)C(=C)CCC2C(C)CO</smiles>

hirsutalin S (177)

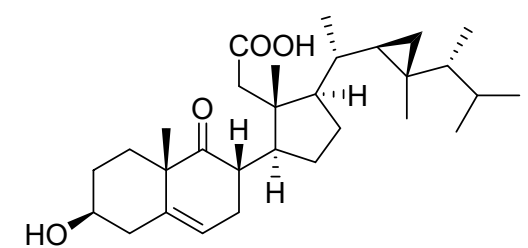

klyflaccisteroid F (180)

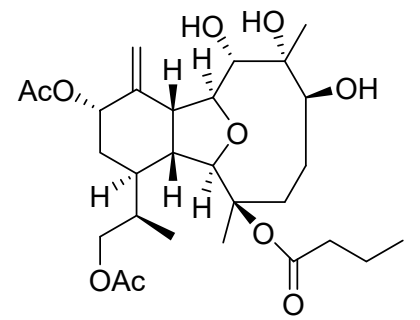

krempfielin R (183)<smiles>CC(C)=CCC/C(C)=C/CC/C(C)=C/CC1=CC(=O)C=C(C)C1=O</smiles>

monanchosterol B (185)

Protoreaster nodosus sterol (186)

Figure 2. Cont. 
<smiles></smiles>

rhytidenone C (187)

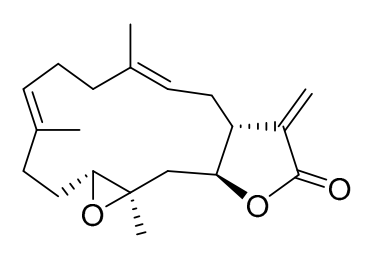

sarcocrassolide E (188)

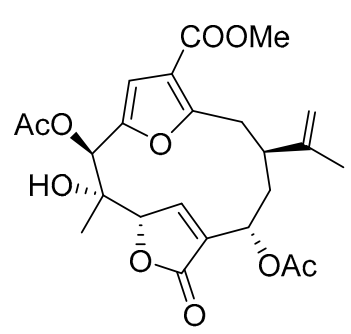

sinulacembranolide A (189)<smiles>CC1=CC(=O)CC2(C)CC[C@H](C(C)(O)CO)CC12</smiles>

thomimarine $B(190)$

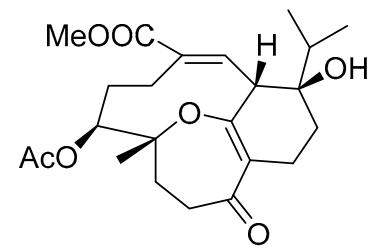

tortuosene A (191)<smiles>COC1=CC2(C(=O)N1C)N(C(C)=O)C(=O)N2C(=O)O</smiles>

Fascaplynopsis reticulata alkaloid 193

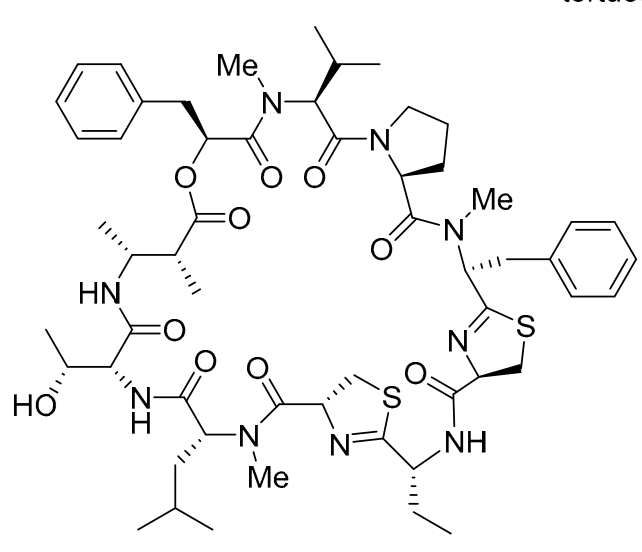

grassypeptolide A (192)

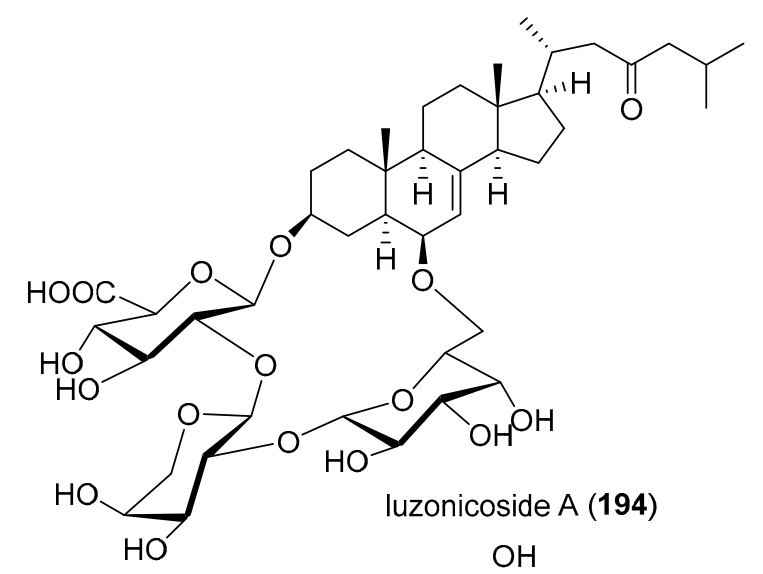

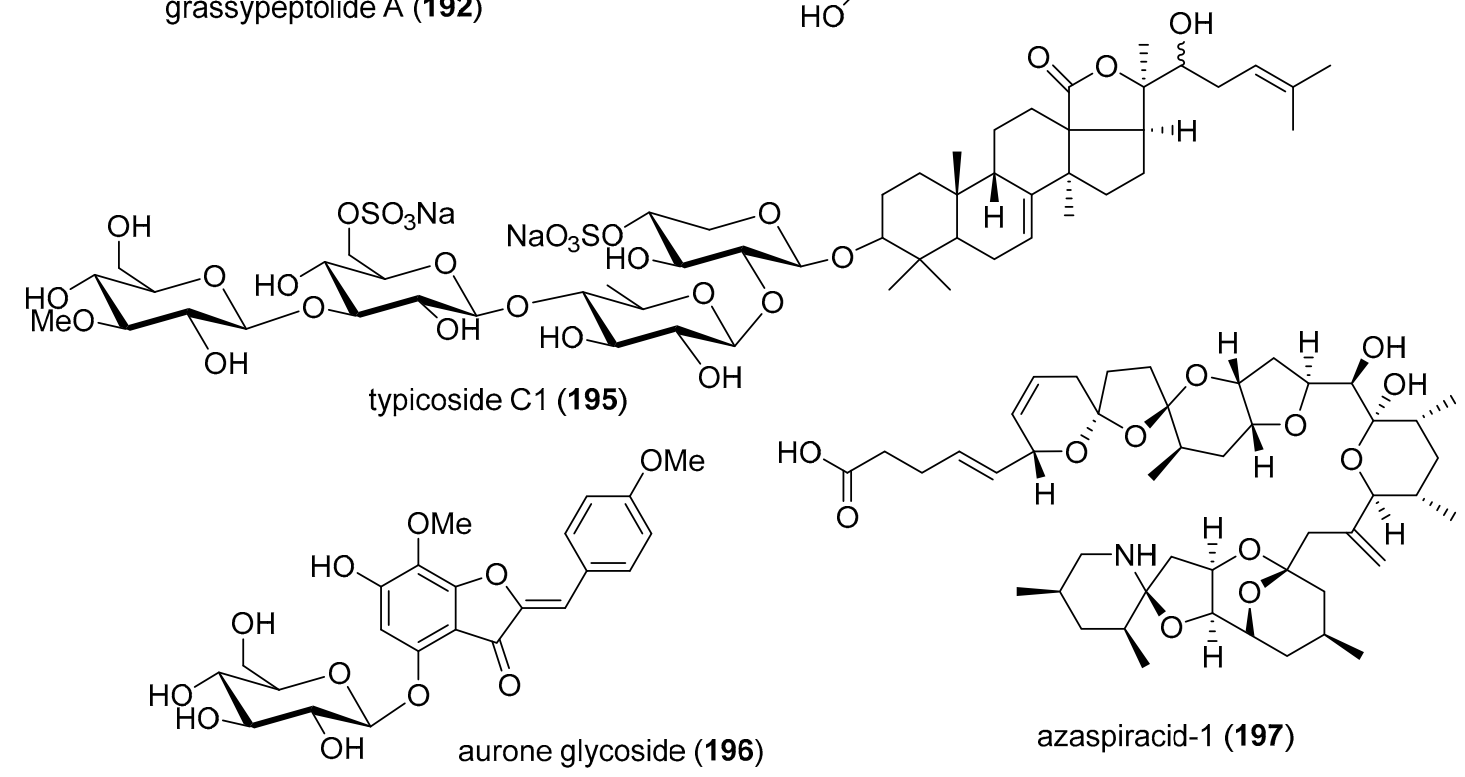

Figure 2. Cont. 
<smiles>COC(=O)/C1=C\c2[nH]c3ccccc3c2/C(C(=O)OC)=C\c2c1[nH]c1ccccc21</smiles>

caulerpine (198)<smiles>C[N+](C)(C)C(Cc1c[nH]c2cc(Br)ccc12)C(=O)[O-]</smiles>

6-bromohypaphorine (199)<smiles>CCc1c(O)c(O)c2c(c1O)C(=O)C(O)=C(O)C2=O</smiles>

echinochrome A (204)
FFHHIFRGIVHVGKTIHRLVTG piscidin-1 (200)
PECCTHPACHVSHPELC $\alpha$-conotoxin $\mathrm{Mr1.7}$ (201)

TGEDFLEECMGGCAFDFCCKR It16a (202)

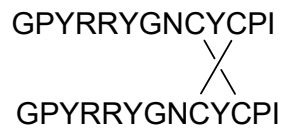

Conus vitulinus peptide 203

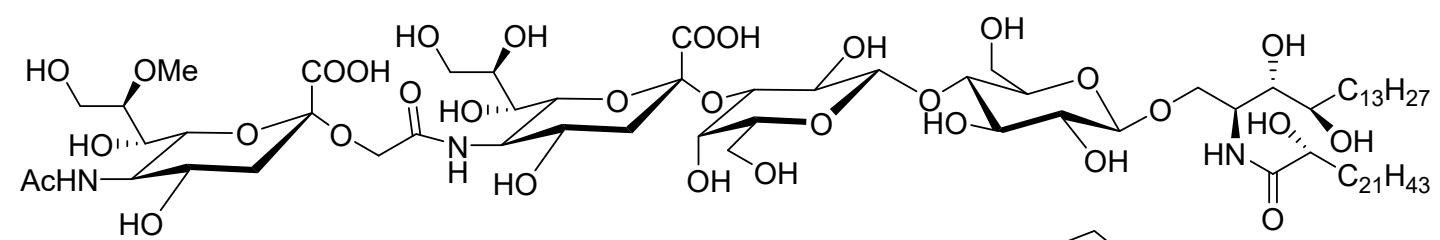

ganglioside LLG-3 (205)<smiles>CC(=O)OC1CC2C3CCC4C(C)(C)CCC[C@]4(C)C3C[C@H](OC(C)=O)[C@@]2(C)[C@@H]2OC(C)=CC12</smiles>

heteronemin (206)

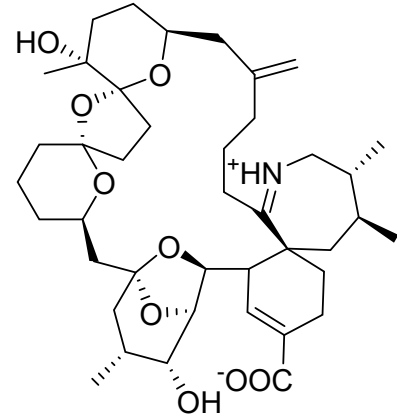

pinnatoxin A (207)

\section{CASQGQKCKTKSDCCNGMWCAGTRGHTCYKPK}

PhcrTx1 (208)<smiles>CCCCCCCCCCCCCC/C=C/C=C/[C@H](O)[C@H](CO)NC(=O)CCCCCCCCCCCC</smiles>

Sarcophyton auritum ceramide (209)

Figure 2. Cont.

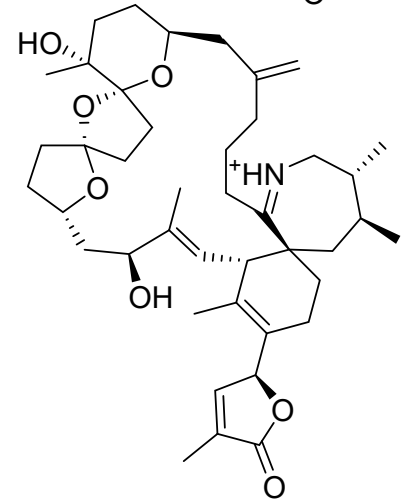

spirolide C (210)<smiles>C=C1CC[C@H]2C(C)(C)CCC[C@]2(C)[C@H]1Cc1cc(O)ccc1O</smiles>

zonarol (211)<smiles>CN(CCc1cc(Br)c(OCCC=[N+](C)C)c(Br)c1)[N+](C)=O</smiles>

aplysinellamide-1 (212) 


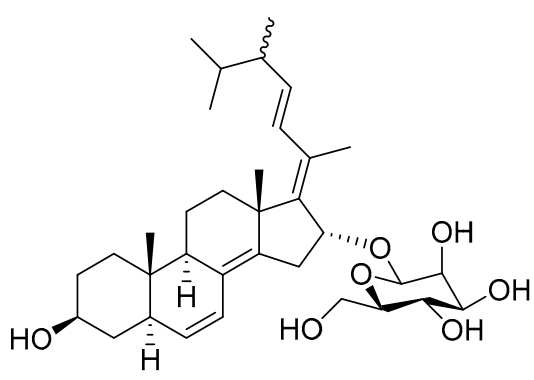

Dichotomomyces cejpii steroid $\mathbf{2 1 4}$<smiles>CC1=NC2C(=O)NC(N)=NC2N1CCC(=O)O</smiles>

genuanine (215)<smiles>C=CCCCC/C=C/C=C(\C)CCCC/C=C/CC/C=C\C(=O)NC(CO)CO</smiles><smiles>CC(=CCCC(C)=CCc1cc(O)ccc1O)CC=C(C)C(C)CCC(C)(C)C</smiles>

Figure 2. Marine pharmacology in 2014-2015: marine compounds with antidiabetic and anti-inflammatory activity, and affecting the immune and nervous system.

\subsection{Antidiabetic Activity}

As shown in Table 2 and Figure 2, four publications reported on the mode of action of marine-derived antidiabetic compounds (10, 134-136). Kang and colleagues contributed to the pharmacology of diabetes by noting that the marine carotenoid fucoxanthin (134), isolated from the marine brown alga Ishige okamurae, protected cells and organs from oxidative damage induced by high glucose both in vitro and in vivo, concluding that "fucoxanthin may prove to be an effective mediator to control oxidative stress in hyperglycemia" [155]. Maeda and colleagues observed that fucoxanthin and its metabolite, fucoxanthinol (135), improved obesity-induced inflammation in adipocyte cells with concomitant suppression of tumor necrosis factor- $\alpha$ and monocyte chemotactic protein-1 RNA expression, thus concluding that fucoxanthin "ameliorates glucose tolerance in the diabetic mice model" [154]. Lee and colleagues reported that octaphlorethol A (136) isolated from the marine brown alga Ishige foliacea showed a potent anti-hyperglycemic effect in mice by potently binding to $\alpha$-glucosidase, an enzyme that plays a role in blood glucose control, thus demonstrating its potential use "for treatment of type 2 diabetes mellitus" [156]. You and colleagues showed that the phlorotannin phlorofucofuroeckol-A (10) isolated from the brown alga Ecklonia cava alleviated postprandial hyperglycemia in diabetic mice by a mechanism that involved significant inhibition of $\alpha$-glucosidase and $\alpha$-amylase, thus proposing this natural product "as a nutraceutical for diabetic individuals" [157].

An additional six marine natural products (137-142), listed in Table 2 and shown Figure 2, demonstrated antidiabetic activity, but the mechanism of action of these compounds remained undetermined at the time of publication. Safavi-Hemami and colleagues described a specialized insulin Con-Ins G1 (137) used for chemical warfare by the fish-hunting cone snail Conus geographus, which appear to have "evolved to act rapidly and potently to cause severe hypoglycemia" [158]. 
Yamazaki and colleagues found that the sesquiterpene dehydroeuryspongin A (138) isolated from the Japanese marine sponge Euryspongia sp. inhibited the protein tyrosine phosphatase 1B, considered a key enzyme involved in type II diabetes and obesity because it plays a role in the dephosphorylation of insulin and leptin receptors [159]. Xia and colleagues contributed a new isopimarane diterpene (139) isolated from the culture of the fungus Epicoccum sp. associated with the marine sea cucumber Apostichopus japonicus that potently inhibited $\alpha$-glucosidase [160]. Shin and colleagues isolated a new benzothioate glycoside suncheonoside A (140) from a Korean marine-derived Streptomyces strain that promoted adiponectin production during adipogenesis in vitro, thus "suggesting antidiabetic potential" [161]. You and colleagues reported that the lumazine-containing peptide terrelumamide A (141), isolated from the culture broth of the Korean marine-derived fungus Aspergillus terreus, improved insulin sensitivity and adiponectin production in an in vitro human adipogenesis model [162]. He and colleagues characterized a polyunsaturated lipid (142) from the Chinese marine sponge Xestospongia testudinaria, which was shown to inhibit protein tyrosine phosphatase $1 \mathrm{~B}$, considered as a significant target for the "treatment of type II diabetes and obesity" [163].

\subsection{Anti-Inflammatory Activity}

As shown in Table 2 and Figure 2, there was a remarkable increase in anti-inflammatory pharmacology of marine compounds (143-191) during 2014-2015. The molecular mechanism of action of marine natural products (143-163) was assessed in both in vitro and in vivo preclinical pharmacological studies in twenty-two papers that used several in vitro models: the murine RAW 264.7 macrophages, a human keratinocyte cell line, a human hepatocarcinoma HepG2 cell line, primary rat brain microglia, and a murine microglia BV-2 cell line.

Taira and colleagues evaluated the anti-inflammatory properties of alcyonolide and its congener $(\mathbf{1 4 3}, \mathbf{1 4 4})$, isolated from the Okinawan soft coral Cespitularia sp. in lipopolysaccharide (LPS)-stimulated RAW264.7, observing inhibition of $\mathrm{NO}$ as well as gene expression of the proinflammatory genes inducible nitric oxide synthase (iNOS) and cyclooxygenase (COX)-2 mRNA [164]. Guo and colleagues extended the pharmacology of the terpenoid astaxanthin (145) by reporting that a reduction of oxidative stress in an in vivo model of rat burn injury was concomitant with a decrease in the level of malondialdehyde, an indicator of lipid peroxidation, as well as an increase of antioxidant enzymes superoxide dismutase and catalase, a "protective effect" that held "potential as a new drug treatment of severely burned patients ..." [165]. Yang and colleagues reported that the polyketide 8,8'-bieckol (146), isolated from the edible marine brown alga Ecklonia cava, significantly inhibited both pro-inflammatory NO, prostaglandin $\mathrm{E}_{2}\left(\mathrm{PGE}_{2}\right)$, and interleukin 6 (IL-6) production, as well as gene expression by downregulating NF- $\mathrm{B}$ signaling pathway and ROS accumulation in both LPS-stimulated primary macrophages and RAW 264.7 macrophages, thus demonstrating the compound's "anti-inflammatory potential ... in systemic inflammatory conditions such as sepsis" [166]. Fernandes and colleagues studied convolutamydine A (147), isolated from marine bryozoan Amathia convoluta, and two synthesized analogs, and determined that they exhibited significant in vivo and in vitro anti-inflammatory activity by a mechanism that involved reduced leukocyte migration as well as inhibition of the production of the cytokine IL-6, PGE 2 , and NO [167]. Phan and colleagues isolated a new bicyclogermacrene capgermacrene A (148) from the Bornean soft coral Capnella sp. and observed significant in vitro inhibition of NO production by RAW 264.7 macrophages by inhibition of iNOS expression, proposing this compound as a "promising iNOS inhibiting agent" [168]. Jiménez-Romero and colleagues investigated the effect of the diterpene dactyloditerpenol acetate (149) extracted from the Puerto Rican tropical sea hare Aplysia dactylomela on E. coli LPS-activated rat neonatal microglia in vitro, observing the potent inhibition of both thromboxane $\mathrm{B}_{2}$ and superoxide anion $\left(\mathrm{O}_{2}{ }^{-}\right)$ generation, proinflammatory mediators associated with neuroinflammation, concluding that the data "support further development" of this compound [169]. Two studies extended the anti-inflammatory pharmacology of dieckol (150) isolated from the brown alga Ecklonia cava: Choi and colleagues demonstrated the compound inhibited LPS-induced iNOS expression by affecting mitogen-activated 
protein kinases (MAPK), "significantly p38MAPK" in the mouse macrophage 264.7 cell line in vitro [170], while Kang and colleagues demonstrated that dieckol suppressed production of macrophage-derived chemokine, $\mathrm{C}-\mathrm{C}$ motif chemokine 22 , an inflammatory chemokine that controls leukocyte movements by down-regulating the activation of the signal transducer and activator of transcription (STAT)1 signaling pathway in human keratinocytes [171]. Lin and colleagues characterized the anti-inflammatory effects of the diterpene excavatolide B (151) isolated from the cultured Formosan marine gorgonian Briareum excavatum and observed that, in vitro, it inhibited iNOS and COX-2 mRNA expression in LPS-treated murine RAW 264.7 macrophages, while in vivo it attenuated carrageenan-induced rat paw inflammation and pain, thus concluding that "excavatolide B may serve as a useful therapeutic agent for the treatment of acute inflammation" [172]. Chen and colleagues investigated the antinociceptive properties of flexibilide (152), isolated from the Australian soft coral Sinularia flexibilis in the rat chronic injury model of neuropathic pain, observing significant analgesic effects concomitant with suppression of iNOS expression in microglia and astrocytes in the spinal dorsal horn, accompanied with upregulation of transforming growth factor- $\beta 1$ (TGF- $\beta 1$ ), "suggesting involvement of TGF- $\beta 1$ in the anti-neuroinflammatory and analgesic effects" [173]. Kim and colleagues reported that a polyhydroxyflavone (153) isolated from the marine alga Hizikia fusiforme suppressed LPS-stimulated RAW 264.7 cells' release of pro-inflammatory cytokines, as well as both iNOS and COX-2 expression, by attenuating nuclear transcription factor- $\mathrm{KB}(\mathrm{NF}-\mathrm{kB})$ translocation, and thus might become a "potential therapeutic agent for patients with, or at risk of, septic shock or other inflammatory diseases" [174]. Wijesinghe and colleagues evaluated $5 \beta$-hydroxypalisadin B (154), a brominated secondary metabolite isolated from the Malaysian marine red alga Laurencia snackeyi, on LPS-stimulated RAW 264.7 macrophages and observed significant reduction of several pro-inflammatory cytokines, NO, and $\mathrm{PGE}_{2}$ generation, and thus concluded that the compound might help development of "an active ingredient in pharmaceutical, nutraceutical ... " applications [175]. Huang and colleagues characterized two novel biscembranes glaucumolides A and B $(155,156)$ from the cultured soft coral Sarcophyton glaucum that significantly inhibited $\mathrm{O}_{2}{ }^{-}$generation and elastase release in human neutrophils, while also reducing expression of iNOS and COX-2 in LPS-treated murine RAW 264.7 macrophages, concluding that these two compounds "might be useful for future biomedical applications" [176]. Yu and colleagues determined that the effects of phlorofucofuroeckol-B (157), isolated from the marine alga Ecklonia stolonifera, on the decreased production of pro-inflammatory mediators by LPS-stimulated BV-2 microglia cells, as well as reduced COX-2 and iNOS expression, resulted from inhibition of the $i \kappa B-\alpha / N F-\kappa B$ and Akt/ERK/JNK pathways, thus proposing that this compound might be "considered as a therapeutic agent against neuroinflammation" [177]. Babskota and colleagues isolated a new phosphatidylglycerol (158) from an extract of the marine red alga Palmaria palmata, also commonly known as dulse, which strongly inhibited NO release from LPS treated murine RAW 264.7 macrophages, probably by a mechanism that down-regulated iNOS, thus suggesting that "consumption of dulse as a functional food may help to reduce inflammation associated with various diseases" [178]. Itoh and coleagues showed that reduced scytonemin (159) isolated from the cosmopolitan colonial cyanobacterium Nostoc commune strongly inhibited LPS and interferon- $\gamma$-induced NO production in murine macrophage RAW 264.7 macrophages, by generating reactive oxygen species by activation of the phosphatidylinositol-3-kinase/Akt and the p38 mitogen-activated protein kinase/nuclear factor erythroid 2-related factor 2 signaling pathways [179]. Lillsunde and colleagues reported that a norcembranoid sinuleptolide (160) isolated from the Indian soft coral Sinularia kavarattiensis potently modulated both morphology and release of pro-inflammatory and anti-inflammatory mediators by LPS-treated rat primary microglial cells in vitro, thus decreasing microglia activation, which has been hypothesized to be involved in the "progression of chronic neurodegenerative diseases.. and central nervous system (CNS) homeostasis" [180]. Thao and colleagues contributed a new polyhydroxylated steroid sarcopanol A (161) from the Vietnamese soft coral Sarcophyton pauciplicatum that inhibited tumor necrosis factor (TNF)- $\alpha$ and interferon (IFN) $\gamma$-induced expression of COX-2, iNOS, and intercellular adhesion molecule-1 (ICAM-1) in the spontaneously transformed immortal human keratinocyte 
cell line HaCaT via inhibition of NF-kB signaling pathway activation [181]. Thao and colleagues investigated the diterpenoid sinumaximol (162), isolated from the marine soft coral Sinularia maxima, and determined that it significantly inhibited TNF- $\alpha$-induced NF- $\mathrm{kB}$ transcriptional activity in a human hepatocarcinoma HepG2 cell line, while concomitantly inhibiting the expression of pro-inflammatory iNOS and ICAM-1mRNA expression, thus supporting the "therapeutic potential as anti-inflammatory" of this compound [182]. Quang con colleagues determined that tanzawaic acid A (163), isolated from a marine fungus Penicillium sp. SF-6013 derived from the Pacific sea urchin Brisaster latifrons, inhibited both $\mathrm{NO}$ and $\mathrm{PGE}_{2}$ production from LPS-activated murine BV-2 microglia cells and RAW 264.7 murine macrophages, while suppressing iNOS and COX-2 expression and inhibiting protein tyrosine phosphatase 1B [183].

In contrast to the marine compounds (143-163) with described anti-inflammatory mechanisms of action described in the preceding paragraph, and as shown in Table 2, for marine compounds (164-191), only anti-inflammatory activity $\left(\mathrm{IC}_{50}\right)$ was reported, but the molecular mechanism of action of these marine-derived compounds remained undetermined at the time of publication: a new highly oxygenated meroterpene aspertetranone D (164) isolated from the marine algal-associated fungus Aspergillus sp. ZL0-1b14 [184]; a novel 6,12-dichlorobriarene diterpenoid briarenolide J (165), two briarane diterpenoids briarenolides $K$ and $L(166,167)$, and the briarenolides $U-W$ (168-169), all compounds isolated from the Taiwanese octocoral Briareum sp. [185-187]; two new briarane diterpenoids briaviolides $\mathrm{E}$ and I $(\mathbf{1 7 0}, \mathbf{1 7 1})$, isolated from the Taiwanese soft coral Briareum violacea [188]; a new pigmented phenazine compound dermacozine $\mathrm{H}$ (172), isolated from the actinomycete Dermacoccus abyssi sp. nov. strain MT1.1, isolated from a Mariana Trench sediment at a depth of 10,898 m [189]; a novel sesquiterpene dysifragilone A (173), isolated from the South China Sea sponge Dysidea fragilis [190]; a new xenicane $4 \alpha$-hydroxypachylactone (174), isolated from a Chinese brown alga Dictyota plectens [191]; a polyketide comaparvin (175), isolated from the Taiwanese marine crinoid Comanthus bennetti [192]; two novel eunicellin-type diterpenoids hirsutalins $N$ and $S(\mathbf{1 7 6}, \mathbf{1 7 7})$ and a new tocopherol-derived metabolite hirsutocospiro A $(\mathbf{1 7 8})$, isolated from the Taiwanese soft coral Cladiella hirsuta [193-195]; a new cembranoid isosinulaflexiolide K (179), isolated from cultured Taiwanese soft corals Sinularia sandensis and Sinularia flexibilis [196]; a novel 9,11-secogorgosteroid klyflaccisteroid F (180), isolated from the Taiwaneses soft coral Klyxum flaccidum [197]; new eunicellin-type diterpenoids krempfielins N (181), Q (182), and R (183), isolated from a Taiwanese soft coral Cladiella krempfi [198,199]; a methylfarnesylquinone (184), isolated from the Taiwanese marine brown alga Homeostrichus formosana [200]; a novel steroid monanchosterol B (185), isolated from the Korean sponge Monanchora sp. [201]; a oxygenated steroid derivative (186), isolated from the Vietnamese starfish Protoreaster nodosus [202]; a new spirobisnaphthalene rhytidenone C (187), isolated from an extract of a cultured fungal endophyte Rhytidhysteron sp. AS21B isolated from a Thailandese mangrove area [203]; a known terpenoid sarcocrassocolide E (188), isolated from a Taiwanese soft coral Sarcophyton crassocaule [204]; a new cembrane diterpenoid sinulacembranolide A (189), isolated from the Taiwanese soft coral Sinularia gaweli [205]; a new eudesmane-type sesquiterpene thomimarine B (190), isolated from the fungus Penicillium thomii KMM 4667 isolated from the Japanese sea grass Zostera marina [206]; and a novel diterpenoid tortuosene A (191), isolated from the Taiwanese soft coral Sarcophyton tortuosum [207].

\subsection{Marine Compounds with Activity on the Immune System}

As shown in Table 2 and Figure 2, the preclinical pharmacology of marine compounds that affected the immune system showed a decline, as previously reported in this series.

Kwan and colleagues reported that the peptide grassypeptolide A (192), isolated from the marine cyanobacterium Lyngbya confervoides, inhibited IL-2 production and proliferation of activated $\mathrm{T}$ cells by inhibiting the protease dipeptidyl peptidase 8 , probably by binding at inner cavity of the enzyme at two distinct sites [208]. Wang and colleagues isolated a pair of novel bisheterocyclic quinolone-imidazole alkaloids (+)- and (-) spiroreticulatine (193) from the South China sea sponge 
Fascaplysinopsis reticulata, which showed inhibition of IL-2 production by Jurkat T cells [209]. Kicha and colleagues determined that the cyclic steroid glycoside luzonicoside A (194), isolated from the starfish Echinaster luzonicus, potently enhanced lysosomal activity, ROS level elevation, and NO synthesis in RAW 264.7 murine macrophages, thus seeming "promising for further investigation as a potent immunomodulatory agent" [210]. Pislyagin and colleagues investigated a triterpene glycoside typicoside $C_{1}$ (195), isolated from the sea cucumber Actinocucumis typica, and observed that it demonstrated strong immunostimulatory effect on ROS formation in mouse peritoneal macrophages in vitro, with concomitant low cytotoxicity [211].

\subsection{Marine Compounds Affecting the Nervous System}

As shown in Table 2 and Figure 2, in 2014-2015, the preclinical marine nervous system pharmacology of compounds (196-211) described several mechanism of action: at the nicotinic acetylcholine receptor and potassium channels, with conopeptides, and in models of antinociception and neuroprotection.

Four marine compounds were shown to bind nicotinic acetylcholine receptors (nACHR) (199, $207,210)$ and potassium $\left(\mathrm{K}^{+}\right)$channels $(208)$. Kasheverov and colleagues determined the effect of 6-bromohypaphorine (6-BHP) (199), isolated from the marine nudibranch mollusk Hermissenda crassicornis, on different $\mathrm{nAChR}$, demonstrating that, because 6-BHP competed with $\alpha$-bungarotoxin for binding to the human $\alpha 7 \mathrm{nAChR}$, it was the "first low-molecular weight compound from (a) marine source which (was) an agonist of the nACHR subtype" [215]. Bourne and colleagues conducted detailed studies to determine the molecular pharmacology of the macrocylic imine phycotoxin pinnatoxin A (207), originally isolated from the digestive glands of the mollusk Pinna attenuata, towards neuronal $\alpha 7 n A C H R$, observing that the bicyclic EF-ketal ring was a novel binding determinant for mediating polar versus non-polar interactions, and thus is able to "confer nAChR subtype selectivity ... (of) these prevalent marine biotoxins" [223]. Rodríguez and colleagues discovered a novel peptide PhcrTx1 (208) from the sea anemone Phymanthus crucifer that inhibited voltage-gated $\mathrm{K}^{+}$ion channels, including acid-sensing ion channel (ASIC) $\left(\mathrm{IC}_{50}=100 \mathrm{nM}\right)$, and that would represent "the first member of a new structural group of sea anemone toxins acting on ASIC" [224]. Aráoz and colleagues extended the pharmacology of the "fast-acting" lipophilic marine toxin 13,19-desmethyl spirolide C (210), extracted from cultures of the dinoflagellate Alexandrium ostenfeldii, defining the mode of action and molecular targets using in vitro electrophysiological experiments, and thus showing that the toxin blocked human neuronal nACHR $\left(\mathrm{IC}_{50}=0.2 \mathrm{nM}\right)$ with high affinity, observations supported by molecular docking experiments "highlighting the nicotinic basis of the neurotoxicity of (this toxin) to mammal(ian) ... peripheral and central nervous system" [227].

Three studies extended the pharmacology of conopeptides (201-203). Wang and colleagues discovered a novel $\alpha$-conotoxin Mr1.7 (201) in the venom of the marine snail Conus marmoreus that inhibited $\alpha 3 \beta 2, \alpha 9 \alpha 10$, and $\alpha 6 / \alpha 3 \beta 2 \beta 3 \mathrm{nACHR}$ subtypes ( $\mathrm{IC}_{50}=53.1,185.7$, and $284.2 \mathrm{nM}$, respectively), noting that the $\mathrm{PE}$ residues at the $\mathrm{N}$-terminal sequence of Mr1.7 were "important for modulating activity and selectivity" [217]. Zhou and colleagues reported the expression and sodium channel activity of peptide It16a (202), a novel framework XVI conotoxin from the M-superfamily isolated from the worm-hunting snail $C$. litteratus, and, using a variety of electrophysiological techniques, demonstrated that it preferentially inhibited voltage-gated $\mathrm{Na}^{+}$channels (apparent $\mathrm{IC}_{50}=1 \mu \mathrm{M}$ ) in mammalian sensory neurons, with the authors noting "It16a ... has similar function as $\mu$-conotoxins" [218]. Li and colleagues extended the pharmacology of Vt3.1 conotoxin (203), isolated from the venom of the marine cone snail C. vitulinus, and demonstrated that it preferentially inhibited large conductance, voltage, and $\mathrm{Ca}^{2+}$ activated $\mathrm{K}^{+}(\mathrm{BK})$ channels containing the $\beta 4$ subunit $\left(\mathrm{IC}_{5}=8.5 \mu \mathrm{M}\right)$, which appears to be present in brain and neuronal functions by a mechanism that required electrostatic interactions with the channel protein, making it an excellent tool "uniquely suited in neuroscience involving BK channels" [219].

Two studies reported marine compounds $(\mathbf{1 9 8}, \mathbf{2 0 0})$ that contributed to nociceptive pharmacology. Cavalcante-Silva and colleagues assessed the mechanism involved in in vivo antinociception produced 
by the bisindole alkaloid caulerpine (198), isolated from the marine alga Caulerpa, demonstrating that, in the in vivo murine writhing test, the effect was likely mediated by "pathways involving $\alpha 2$-adrenoceptors and 5-HT3 receptors", thus proposing cualerpine as a possible "dual-action analgesic drug(s)" [214]. Chen and colleagues investigated the anti-neuropathic properties of the antimicrobial peptide piscidin (200) and observed that the compound demonstrated in vivo anti-nociceptive effects in a rat model of neuropathy by a signaling mechanism that suppressed up-regulation of interleukin-1 in microglia and phosphorylated mammalian target of rapamycin in astrocytes, concluding it "may have potential for development as an alternative pain-alleviating agent" [216].

The neuroprotective activity of marine compounds (196, 197, 205, 206, 211) was reported in five studies. $\mathrm{Wu}$ and colleagues observed that the novel (Z)-7,4'-dimethoxy-6-hydroxy-aurone-4-O- $\beta$-glucopyranoside (196) isolated from the endophytic fungus Penicillium citrinum of the mangrove Bruguiera gymnorrhyza derivative decreased 1-methyl-4-phenylpyridium-induced neurotoxicity in rat pheochromocytoma PC12 cells in vitro by a mechanism that elevated mitochondrial membrane potential, decreased DNA fragmentation, and inhibited apoptosis [212]. Hjornevik and colleagues completed an extensive in vitro "neurotoxicological" study with the marine algal toxin azaspiracid-1 (197) and observed rat PC12 cells' differentiation-related morphological changes associated with the expression of the PC12-associated neuronal differentiation marker peripherin on neurite-like processes, suggesting this molecule "triggers a differentiation process" [213]. Yamagishi and colleagues explored the structure-activity relationship of LLG-3 (205), a ganglioside isolated from the starfish Linchia laevigata, and discovered that the methyl group at $\mathrm{C} 8$ of the terminal sialic acid residue was of critical significance for neuritogenic activity. Furthermore, detailed signaling studies revealed the "activation of mitogen-activated protein kinase signaling pathway" [221]. Cassiano and colleagues, using chemical proteomics, noted that the terpenoid heteronemin (206), isolated from the marine sponge Hyrtios sp., targeted TDP-43, a major component of inclusions that characterize amyotrophic lateral sclerosis and front-temporal lobar degeneration, by lowering its affinity "towards nucleic acids", and thus becoming a "relevant chemical tool in the study of TDP-43 related processes" [222]. Shimizu and colleagues provided the "first report" that the pro-electrophilic sesquiterpene zonarol (211), isolated from the Japanese brown alga Dictyopteris undulata, provided neuroprotection by activating the nuclear factor (erythroid-derived-2)-like 2/antioxidant responsive element Nrf2/ARE pathway, inducing phase-2 enzymes and providing oxidative stress protection to cerebrocortical neurons in vitro, concluding that the compound "represents a lead compound for the treatment of chronic neurodegenerative diseases associated with oxidative stress" [228].

As shown in Table 2, three marine compounds were shown to modulate other molecular targets, that is, $\gamma$-aminobutyric acid (GABA) receptor (209), and the acetylcholinesterase (204) and butyrylcholinesterase enzyme (10). Lee and colleagues discovered that the pigment echinochrome A (204), isolated from the sea urchin Scaphechinus, inhibited acetylcholinesterase $\left(\mathrm{IC}_{50}=16.4 \mu \mathrm{M}\right)$ by an irreversible and uncompetitive mechanism that might be useful in "treating acetylcholine-limited diseases", such as Alzheimer's disease and "other forms of dementia" [220]. Eltahawy and colleagues isolated of a new ceramide (209) from the Red sea soft coral Sarcophyton auritum, which demonstrated antiepileptic activity in vivo with a central nervous system depressing mechanism that appeared to involve "GABA receptor modulation rather than serotonin receptor inhibition" [226]. Choi and colleagues reported that the polyphenol phlorofucofuroeckol-A (10), isolated from the Korean brown alga Ecklonia cava, potently inhibited butyrylcholinesterase, a novel target for Alzheimer's disease, suggesting that "phlorotannins ... to be very promising medicinal compounds" [225].

In contrast to the marine compounds affecting the nervous system with investigated mechanisms of action discussed above, and as shown in Table 2, for marine compounds (120, 121, 212-218), only an $\mathrm{IC}_{50}$ was reported, but the molecular mechanism of action of these compounds remained undetermined at the time of publication: an Australian marine-sponge Aplysinella sp.-derived aplysinellamide-1 (212) [229], the novel lactones territrem $D$, and arisugacin A $(\mathbf{1 2 0}, \mathbf{1 2 1})$ from a fungus Aspergillus terreus 
SCSGAF0162 derived from a South China sea gorgonian Echinogorgia aurantiaca [115]; an Indian marine cone snail Conus araneosus ar3j peptide (213) [230]; a new steroid (214) from a fungus Dichotomomyces cejpii isolated from an Australian marine sponge Callyspongia cf. C. flammea [231]; a novel genuanine (215) isolated from Cape Verde marine cone snail Conus genuanus [232]; a bromotyrosine alkaloid homoaerothionin (216) isolated from the Thai sponge Acanthodendrilla sp. [233]; a new alkyl amide mooreamide A (217) from the Papua New Guinean marine cyanobacterium Moorea bouillonii [234]; and a hydroxyoctaprenyl $1^{\prime}, 4^{\prime}$-hydroquinone (218) isolated from the Italian marine sponge Sarcotragus spinosulus [235].

\section{Marine Compounds with Miscellaneous Mechanisms of Action}

The 2014-2015 preclinical pharmacology of 83 marine compounds (219-300) with miscellaneous mechanisms of action is shown in Table 3, with their corresponding structures presented in Figure 3. Because, at the time of publication, a comprehensive pharmacological characterization of these compounds remained unavailable, their assignment to a particular drug class will probably require further investigation.

As reported in the peer-reviewed literature, Table 3 presents the pharmacological activity, an $\mathrm{IC}_{50}$, and a molecular mechanism of action of the following marine natural compounds: sea anemone Aiptasia diaphana toxic peptide AdE-1 (219) [236]; sponge alkaloid aaptamine (220) [237]; dinoflagellate Amphidinium sp. polyketide amphirionin-4 (221) [238]; algal terpenoid astaxanthin (145) [239]; sponge alkaloids bastadins 6 and 16 (222, 223) [240]; brown alga Eisenia bicyclis polyketide 6,6-bieckol (224) [241]; Streptomyces sp. strain CNH-287 alkaloid (-)-chlorizidine A (225) [242]; soft coral Cladiella australis dihydroaustrasulfone alcohol (226) [243,244]; edible brown alga Ishige okamurae terpenoid diphlorethohydroxycarmalol (227) [245]; sea urchin Scaphechinus mirabilis alkaloid echinochrome A (204) [246,247]; brown alga Ecklonia stolonifera polyketide eckol (228) [248]; sponge derived fungus Dichotomomyces cejpii terpenoid emindole SB (229) [249]; Arctic Streptomyces nitrosporeus YBH10-5 farnesylquinone (230) [250]; fungus Stachybotrys longispora FG216 pyrano indolone alkaloid fibrinolytic compound 1 (231) [251]; fungus Paecilomyces formosus formosusin A (232) [252]; brown alga Ecklonia cava phlorotannin fucodiphlorethol G (233) [253]; green alga Spirogyra sp. polyphenol gallic acid (234) [254]; cyanobacterium Schizothrix sp. gallinamide A (235) [255]; sponge Stylissa aff. carteri girolline (236) [256]; sponge Spongionella sp. terpenoids gracilins H, A, and L (237-239) [257]; new anemone Heteractis crispa Kunitz-type polypeptides HCRG1 and HCRG2 $(\mathbf{2 4 0 , 2 4 1 )}$ [258]; new sponge Hyrtios sp. sesterterpenoid 2 (242) [259]; sponge Ircinia ramose irciniastatin A (243) [260]; ascidian Eudistoma cf. rigida polyketide lejimalide C (244) [261]; red alga Laurencia brongniartii brominated indole (245) [262]; sponge Neopetrosia sp. pyridine nucleoside neopetroside A (246) [263]; edible brown alga Ecklonia stolonifera phlorotannin phlorofucofuroeckol-A (10) [264]; sponge Theonella swinhoei peptide polytheonamide B (247) [265]; green alga Codium fragile terpenoid siphonaxanthin (248) [266]; deep-sea derived fungus Spiromastix sp. MCCC 3A00308 spiromastixones J and L $(57,249)$ [267]; bacteria Thalassospira sp. CNJ328 and Tistrella bauzanensis TIO7329 thalassospiramide C (250) [268]; mangrove fungus Xylaria sp. xyloketal B (251) [269,270]; and sponge Xestospongia testudinaria brominated polyunsaturated lipid (252) [271].

Also consolidated in Table 3 is the pharmacological activity ( $\mathrm{IC}_{50}$ for enzyme or receptor inhibition) of marine-derived compounds (253-300), but the mechanism of action remained undetermined at the time of publication: a dinoflagellate Dinophysis acuminate new polyether macrolide acuminolide A (253) [272]; fungus Alternaria alternata alternariol derivatives (255-257) [136]; bacterium Streptomyces sp. linear peptide ahpatinin Ac (254) [273]; ascidian Aplidium sp. new dipeptide apliamide D (258) [274]; fungi Penicillium thomii and P. lividum new meroterpenoids austalides 4 and 9 (259, 260) [275]; Streptomyces axinellae axinelline A (261) [276]; dinoflagellate Karenia brevisulcata polyether brevisulcatic acid-4 (262) [277]; green alga Caulerpa racemose $4^{\prime}, 5^{\prime}$-dehydrodiodictyonema A (263) [278]; sponge Dactylospongia metachromia sesquiterpenes nakijiquinone N (264), nakijinol C (266), and known analog 18-hydroxy-5-epi-hyrtiophenol (265) [279]; ascidian Didemnum sp. spiroketals didemnaketals D and E $(\mathbf{2 6 7}, \mathbf{2 6 8})$ [280]; sponge Dysidea avara sesquiterpene dysiquinol D (269) [281]; brown alga Laminaria 
japonica terpenoid fucoxanthin (134) [282]; sponge Xestospongia testudinaria halenaquinol sulfate (270) [283]; sponge Xetospongia sp. halenaquinone derivative, 1-hydroxyethylhalenaquinone (271) [284]; sponge Stylissa massa and S. flabelliformis bromopyrrole alkaloids (272-274) [285]; sponge Callyspongia sp. hymenialdisine (275) [286]; sponge Hyattella sp. hyattellactone A (276) [287]; sponge Hippospongia lachne sesterterpene hippolide derivative (277) [288]; sponge Suberea ianthelliformis ianthelliformisamines A, B, and C $(278,7,8)$ [289]; sponge Plakortis cfr. lita sterols incisterols A5 and A6 (279, 280) [290]; soft coral Lobophytum crissum cembranoid diterpene 2,16:7S,8S,-diepoxy 1,3,11,15-cembratetraene (281) [291]; red alga Laurencia okamurai laurene-type sesquiterpenoid laurokamurane A (282) [292]; gorgonian Echinogorgia pseudossapo alkaloid malonganenone L (283) [293]; fungus Hansfordia sinuosae sesquiterpenoid punctaporonin K (284) [294]; fungus Aspergillus versicolor ZLN-60 cyclic peptide psychrophilin G (285) [295]; green alga Caulerpa racemosa bisindole alklaloid racemosin C (286) [296]; soft coral Sarcophyton ehrenbergi prostaglandin derivative sarcoehrendin B (287) [297]; soft coral Sarcophyton trocheliophorum Marenzeller diterpene sarsolilide A (288) [298]; fungus Stachybotry sp. HH1 ZSDS1F1-2 xanthone derivative stachybogrisephenone B (289) [299]; brown alga Sargassum thunbergii alkapolyene 1 (290) [300]; red alga Palmaria palmata mycosporine-like amino acid shinorine (291) [301]; soft coral Sinularia sp. cyclopentenone sinularone D (292) [302]; fungus Stachybotrys chartarum $\mathrm{N}$-(2-benzenepropanoic acid) stachybotrylactam (293) [303]; sponge Petrosia corticata meroditerpenoids strongylophorine -13/-14 (294) [304]; sponge Theonella swinhoei steroid swinhoeisterol A (295) [305]; brown alga Sargassum thunbergii thunberol (296) [306]; sponge Xestospongia vansoesti meroterpenoid xestosaprol O (297) [307]; sponge Monanchora pulchra bisguanidine alkaloid urupocidin A (298) [308]; sponge Luffariella variabilis $\beta$-carboline alkaloid variabine B (299) [309]; and cyanobacterium Leptolyngbya sp. yoshinone A (300) [310]. 
Table 3. Marine pharmacology in 2014-2015: marine compounds with miscellaneous mechanisms of action.

\begin{tabular}{|c|c|c|c|c|c|c|}
\hline Compound/Organism $^{\text {a }}$ & Chemistry & Pharmacological Activity ${ }^{i}$ & $\mathrm{IC}_{50} \mathrm{~b}$ & MMOA $^{\mathrm{c}}$ & Country $^{d}$ & References \\
\hline AdE-1 (219)/sea anemone & Peptide $\mathrm{g}$ & $\begin{array}{l}\text { Cardiomyocyte action potential } \\
\text { modulation }\end{array}$ & $2 \mathrm{nM}^{*}$ & $\mathrm{Na}^{+}$and $\mathrm{K}^{+}$current increase & ISR & [236] \\
\hline aaptamine $(220) /$ sponge & Alkaloid $\mathrm{g}$ & ROS inhibition & $10 \mu \mathrm{M} *$ & Cytokine inhibition & S. KOR & [237] \\
\hline amphirionin-4 (221)/dinoflagellate & Polyketide ${ }^{\mathrm{e}}$ & $\begin{array}{l}\text { Bone marrow stromal cells proliferation } \\
\text { stimulation }\end{array}$ & $<0.1 \mathrm{ng} / \mathrm{mL}$ & Cytoskeleton protein synthesis & JPN & [238] \\
\hline astaxanthin (145)/alga & Terpenoid ${ }^{\mathrm{f}}$ & Leydig cell steroidogenesis protection & $10 \mu \mathrm{g} / \mathrm{mL}^{*}$ & ROS scavenging & TWN & [239] \\
\hline bastadins 6 and $16(222,223) /$ sponge & Alkaloid $\mathrm{g}$ & Foam cell formation inhibition & $5 \mu \mathrm{M} *$ & ACAT inhibition & JPN & [240] \\
\hline 6,6-bieckol (224)/alga & Polyketide $^{\mathrm{e}}$ & Adipocyte differentiation inhibition & $50 \mu \mathrm{g} / \mathrm{mL}^{*}$ & Adipogenesis inhibition & S. KOR & [241] \\
\hline (-)-chlorizidine A (225)/bacterium & Alkaloid $\mathrm{g}$ & Increase $\mathrm{G}_{1}$ cell cycle phase & $2 \mu \mathrm{M} *$ & GAPDH and hENO1 binding & BRA, USA & [242] \\
\hline $\begin{array}{l}\text { dihydroaustrasulfone alcohol } \\
\text { (226)/soft coral }\end{array}$ & Polyketide ${ }^{\mathrm{e}}$ & $\begin{array}{l}\text { PDGF-induced HASMC proliferation } \\
\text { and angiogenesis inhibition }\end{array}$ & $10 \mu \mathrm{M}$ * & $\begin{array}{l}\text { DNA synthesis and VEGF signaling } \\
\text { inhibition }\end{array}$ & TWN & {$[243,244]$} \\
\hline DPHC (227)/alga & Terpenoid $^{\mathrm{f}}$ & $\begin{array}{l}\text { UVB radiation-induced DNA damage } \\
\text { protection }\end{array}$ & $20 \mu \mathrm{M}^{*}$ & $\begin{array}{l}\text { Nucleotide excision repair system } \\
\text { induction }\end{array}$ & S. KOR & [245] \\
\hline echinochrome A (204)/sea urchin & Alkaloid $\mathrm{g}$ & Cardiac contractility inhibition & $3 \mu \mathrm{M} *$ & SERCA2A inhibition & BEL, S. KOR, RUS & [246] \\
\hline echinochrome A (204)/sea urchin & Alkaloid $g$ & $\begin{array}{l}\text { Increased mitochondria biogenesis and } \\
\text { function }\end{array}$ & $5 \mu \mathrm{M} *$ & $\begin{array}{l}\text { Mitochondrial biogenesis genes } \\
\text { upregulation }\end{array}$ & S. KOR, RUS & [247] \\
\hline eckol (228)/alga & Polyketide ${ }^{\mathrm{e}}$ & ROS suppression in cells & $10 \mu \mathrm{M}^{*}$ & Increased HO-1 expression & S. KOR & [248] \\
\hline emindole SB (229)/fungus & Terpenoid $^{\mathrm{f}}$ & Nonselective $\mathrm{CB}_{1} / \mathrm{CB}_{2}$ antagonist & $\begin{array}{l}2.2-7.0 \mu \mathrm{M} \\
* *\end{array}$ & Undetermined & CHE, DEU & [249] \\
\hline farnesylquinone (230)/bacterium & Polyketide ${ }^{\mathrm{e}}$ & Decreased lipid accumulation & $1 \mu \mathrm{M} *$ & Increased PPAR $\alpha$ activity & CHN, DEU & [250] \\
\hline FGFC1 (231)/fungus & Alkaloid $\mathrm{g}$ & Thrombolysis induction in vivo & $5 \mathrm{mg} / \mathrm{kg}$ * & $\begin{array}{l}\text { Fibrin hydrolysis induction } \\
\text { in vitro }\end{array}$ & $\mathrm{CHN}$ & [251] \\
\hline formosusin $\mathrm{A}(\mathbf{2 3 2}) /$ fungus & Alkaloid $\mathrm{g}$ & $\begin{array}{l}\text { Mammalian DNA polymerase } \beta \\
\text { inhibition }\end{array}$ & $35.6 \mu \mathrm{M}$ & $\begin{array}{l}\text { Competitive and non-competitive } \\
\text { inhibition }\end{array}$ & JPN & [252] \\
\hline fucodiphlorethol (233)/alga & Polyketide $^{\mathrm{e}}$ & ROS inhibition & $10 \mu \mathrm{M} *$ & $\begin{array}{l}\text { Decreased mitochondrial loss, and } \\
\text { caspase-9 expression }\end{array}$ & S. KOR & [253] \\
\hline gallic acid (234)/alga & Shikimate ${ }^{\mathrm{h}}$ & NO-dependent vasorelaxant effect & $12.5 \mu \mathrm{g} / \mathrm{mL}$ & Phospho-eNOS increase & S. KOR & [254] \\
\hline gallinamide A (235)/bacterium & Peptide $^{\mathrm{f}}$ & Human cathepsin L inhibition & $5 \mathrm{nM}$ & Covalent inhibition & USA & [255] \\
\hline girolline $(236) /$ sponge & Alkaloid $\mathrm{g}$ & TLR 5 inhibition & $2 \mu \mathrm{g} / \mathrm{mL}$ & IL-8 and IL-6 inhibition & CAN, NLD, USA & [256] \\
\hline gracilins $\mathrm{A}, \mathrm{H}, \mathrm{L}(237-239) /$ sponge & Terpenoid ${ }^{\mathrm{f}}$ & mPTP opening inhibition & $1 \mu \mathrm{M} *$ & Binding to CypD & EGY, ESP, GBR & [257] \\
\hline $\begin{array}{l}\text { H. crispa polypeptides }(240,241) / \text { sea } \\
\text { anemone }\end{array}$ & Peptide ${ }^{f}$ & $\begin{array}{l}\text { Macrophage TNF- } \alpha, \text { IL- } 6 \text {, and proIL-1 } \beta \\
\text { inhibition }\end{array}$ & & Trypsin and $\alpha$-chemotrypsin inhibition & RUS, TWN & {$[258]$} \\
\hline $\begin{array}{l}\text { Hyrtios sp. sesterterpene } \\
(\mathbf{2 4 2}) / \text { sponge }\end{array}$ & Terpenoid ${ }^{\mathrm{f}}$ & TDP-43 inhibition & $0.4 \mathrm{nM}$ & TDP-43 to DNA binding inhibition & ITA, PYF & [259] \\
\hline
\end{tabular}


Table 3. Cont.

\begin{tabular}{|c|c|c|c|c|c|c|}
\hline Compound/Organism $^{a}$ & Chemistry & Pharmacological Activity ${ }^{i}$ & $\mathrm{IC}_{50} \mathrm{~b}$ & MMOA $^{\mathrm{c}}$ & Country $^{d}$ & References \\
\hline irciniastatin A (243)/sponge & Polyketide $^{\mathrm{e}}$ & TNF- $\alpha$ receptor 1 ectodomain shedding & $10 \mathrm{nM}^{*}$ & ERK activation induced & JPN & {$[260]$} \\
\hline iejimalide C (244)/ascidian & Polyketide ${ }^{\mathrm{e}}$ & V-ATPase inhibitor & $0.12 \mu \mathrm{M}$ & Bafilomycin site binding & JPN & [261] \\
\hline Laurencia sp. indole (245)/alga & Alkaloid $\mathrm{g}$ & Aryl hydrocarbon receptor agonist & $10 \mu \mathrm{M}^{*}$ & $\begin{array}{l}\text { DNA binding stimulation and } \\
\text { CYP1A1 induction }\end{array}$ & JPN, USA & [262] \\
\hline neopetroside A (246)/sponge & Alkaloid $\mathrm{g}$ & $\begin{array}{l}\text { Cardiomyocyte mitochondrial } \\
\text { upregulation }\end{array}$ & $10 \mu \mathrm{M}^{*}$ & $\begin{array}{l}\text { Increased ATP levels and } \mathrm{O}_{2} \\
\text { consumption }\end{array}$ & RUS, S. KOR & [263] \\
\hline Phlorofucofuroeckol-A (10)/alga & Polyketide $^{\mathrm{e}}$ & Lipid accumulation inhibition & $18 \mu \mathrm{M}$ & Decreased PPAR $\gamma$ expression & S. KOR & {$[264]$} \\
\hline polytheonamide B (247)/sponge & Peptide $g$ & $\begin{array}{l}\text { One-ion pore channel permeation } \\
\text { determined }\end{array}$ & NA & $\begin{array}{l}\text { Two ion binding sites defined, but } \\
\text { second ion excluded }\end{array}$ & JPN & {$[265]$} \\
\hline siphonaxanthin (248)/alga & Terpenoid $^{\mathrm{f}}$ & Adipogenesis inhibition & $5 \mu \mathrm{M}$ & Transcription factor inhibition & JPN & [266] \\
\hline $\begin{array}{l}\text { spiromastixones J and L (57, } \\
\text { 249)/fungus }\end{array}$ & Polyketide ${ }^{\mathrm{e}}$ & Cholesterol uptake inhibition & $10 \mu \mathrm{M} *$ & $\operatorname{PPAR} \gamma$ upregulation & $\mathrm{CHN}$ & [267] \\
\hline thalassospiramide $C(\mathbf{2 5 0})$ /bacterium & Peptide $\mathrm{g}$ & HCAN1 inhibition & $3.4 \mathrm{nM}$ & Binding to Cys115 residue & CHN, USA & {$[268]$} \\
\hline xyloketal B (251)/fungus & Polyketide $^{\mathrm{e}}$ & Atherosclerotic plaque attenuation & $14 \mathrm{mg} / \mathrm{kg} * * *$ & Increased eNOS activity & CAN, CHN & [269] \\
\hline xyloketal B (251)/fungus & Polyketide ${ }^{\mathrm{e}}$ & $\begin{array}{l}\text { P450 3a activity and expression } \\
\text { regulation }\end{array}$ & $14 \mathrm{mg} / \mathrm{kg} * * *$ & $\begin{array}{l}\text { Active site binding determined by } \\
\text { docking studies }\end{array}$ & CHN, USA & [270] \\
\hline X. testudinaria lipid (252)/sponge & Polyketide ${ }^{\mathrm{e}}$ & Pancreatic lipase inhibition & $3.11 \mu \mathrm{M}$ & Triglyceride level decrease in vivo & CHN, ITA & [271] \\
\hline acuminolide A (253)/dinoflagellate & Polyketide ${ }^{\mathrm{e}}$ & Stimulation of actomyosin ATPase & $1 \mu \mathrm{M} *$ & Undetermined & S. KOR & [272] \\
\hline ahpatinin Ac (254)/bacterium & Peptide $\mathrm{g}$ & Pepsin inhibition & $11 \mathrm{nM}$ & Undetermined & JPN & {$[273]$} \\
\hline 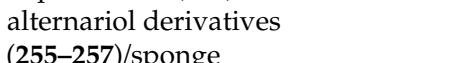 & Shikimate ${ }^{\mathrm{h}}$ & $\mathrm{HCV}$ protease inhibition & $12-52 \mu \mathrm{g} / \mathrm{mL}$ & Undetermined & EGY, SAU & [136] \\
\hline apliamide D (258)/ascidian & Peptide $\mathrm{g}$ & $\mathrm{Na}^{+} / \mathrm{K}^{+}$-ATPase inhibition & $3.2 \mu \mathrm{M}$ & Undetermined & S. KOR & {$[274]$} \\
\hline austalides 4 and $9(\mathbf{2 5 9}, \mathbf{2 6 0}) /$ fungus & Terpenoid $^{\mathrm{f}}$ & Endo-1,3- $\beta$-D-glucanase inhibition & $0.01 \mu \mathrm{M}$ & Undetermined & RUS & {$[275]$} \\
\hline axinelline A (261)/bacterium & Alkaloid $\mathrm{g}$ & COX-2 inhibition & $2.8 \mu \mathrm{M}$ & Undetermined & $\mathrm{CHN}$ & {$[276]$} \\
\hline $\begin{array}{l}\text { brevisulcatic acid-4 } \\
\text { (262)/dinoflagellate }\end{array}$ & Polyketide $^{\mathrm{e}}$ & Activation of sodium channels & $20 \mathrm{ng} / \mathrm{mL}$ & Undetermined & JPN, NZL & {$[277]$} \\
\hline $\begin{array}{l}4^{\prime}, 5^{\prime} \text {-dehydrodiodictyonema } \\
(263) / \text { alga }\end{array}$ & Terpenoid $^{\mathrm{f}}$ & PTP1B inhibition & $2.3 \mu \mathrm{M}$ & Undetermined & $\mathrm{CHN}$ & [278] \\
\hline $\begin{array}{l}\text { D. metachromia sesquiterpenes } \\
(\mathbf{2 6 4 - 2 6 6 ) / s p o n g e ~}\end{array}$ & Terpenoid $^{\mathrm{f}}$ & Multiple kinases inhibition & $0.97-4.8 \mu \mathrm{M}$ & Undetermined & CHN, NLD, DEU & [279] \\
\hline $\begin{array}{l}\text { didemnaketals D and E (267, } \\
\text { 268)/ascidian }\end{array}$ & Terpenoid $^{\mathrm{f}}$ & Multiple kinases inhibition & $10 \mu \mathrm{g} / \mathrm{mL}^{*}$ & Undetermined & EGY & [280] \\
\hline
\end{tabular}


Table 3. Cont.

\begin{tabular}{|c|c|c|c|c|c|c|}
\hline Compound/Organism $^{a}$ & Chemistry & Pharmacological Activity ${ }^{i}$ & $\mathrm{IC}_{50} \mathrm{~b}$ & MMOA $^{\mathrm{c}}$ & Country $^{d}$ & References \\
\hline dysiquinol D (269)/sponge & Terpenoid $^{\mathrm{f}}$ & NF- $\mathrm{KB}$ inhibition & $0.81 \mu \mathrm{M}$ & Undetermined & AUS, CHN & [281] \\
\hline fucoxanthin (134)/alga & Terpenoid $^{\mathrm{f}}$ & Hydroxyl radical-scavenging & $10 \mu \mathrm{g} / \mathrm{mL}^{*}$ & Undetermined & $\mathrm{CHN}$ & [282] \\
\hline halenaquinol sulfate (270)/sponge & Polyketide $^{\mathrm{e}}$ & CDK9 and DYRK1A inhibition & $0.5-0.61 \mu \mathrm{M}$ & Undetermined & FRA, NZL & [283] \\
\hline $\begin{array}{l}\text { 1-hydroxyethylhalenaquinone } \\
\text { (271)/sponge }\end{array}$ & Polyketide ${ }^{\mathrm{e}}$ & $\begin{array}{l}\text { Proteasome-chymotrypsin-like activity } \\
\text { inhibition }\end{array}$ & $0.19 \mu \mathrm{M}$ & Undetermined & IDN, JPN, NLD & [284] \\
\hline $\begin{array}{l}\text { hymenialdisine derivatives } \\
(272-274) \text { /sponge }\end{array}$ & Alkaloid $\mathrm{g}$ & PfGSK-3 inhibition & $0.07-0.2 \mu \mathrm{M}$ & Undetermined & $\begin{array}{l}\text { DEU, EGY, FRA, } \\
\text { NLD }\end{array}$ & [285] \\
\hline hymenialdisine (275)/sponge & Alkaloid $\mathrm{g}$ & CK1, CDK5, GSK3 $\beta$ inhibition & $\begin{array}{l}0.03-0.16 \\
\mu \mathrm{M}\end{array}$ & Undetermined & AUS & [286] \\
\hline hyattellactone A (276)/sponge & Terpenoid $^{\mathrm{f}}$ & PTP1B inhibition & $7.45 \mu \mathrm{M}$ & Undetermined & IDN, JPN & [287] \\
\hline $\begin{array}{l}\text { H. lachne sesterterpenoid } \\
\text { (277)/sponge }\end{array}$ & Terpenoid ${ }^{\mathrm{f}}$ & PTP1B inhibition & $5.2 \mu \mathrm{M}$ & Undetermined & $\mathrm{CHN}$ & [288] \\
\hline $\begin{array}{l}\text { ianthelliformisamines A-C }(278,7 \text {, } \\
\text { 8)/ sponge }\end{array}$ & Alkaloid $\mathrm{g}$ & Carbonic anhydrase inhibition & $0.2-0.85 \mu \mathrm{M}$ & Undetermined & AUS, ITA & [289] \\
\hline $\begin{array}{l}\text { incisterols A5 and A6 (279, } \\
\text { 280)/sponge }\end{array}$ & Terpenoid $^{\mathrm{f}}$ & PXR agonists & $10 \mu \mathrm{M}^{*}$ & Undetermined & ITA & [290] \\
\hline $\begin{array}{l}\text { L. crassum cembranoid (281)/soft } \\
\text { coral }\end{array}$ & Terpenoid $^{\mathrm{f}}$ & PPAR transcription activation & $2.07 \mu \mathrm{M}$ & Undetermined & VNM & [291] \\
\hline L. okamurai terpenoid (282)/alga & Terpenoid $^{\mathrm{f}}$ & PTP1B inhibition & $4.9 \mu \mathrm{g} / \mathrm{mL}$ & Undetermined & $\mathrm{CHN}$ & [292] \\
\hline malonganenone L (283)/sea whip & Alkaloid $\mathrm{g}$ & PDE4D inhibition & $8.5 \mu \mathrm{M}$ & Undetermined & $\mathrm{CHN}$ & [293] \\
\hline punctaporonin $\mathrm{K}(\mathbf{2 8 4}) /$ fungus & Terpenoid $^{\mathrm{f}}$ & Lipid-lowering effect & $10 \mu \mathrm{M}$ * & Undetermined & CHN, DEU & [294] \\
\hline psychrophilin G (285)/fungus & Peptide g & Lipid-lowering effect & $10 \mu \mathrm{M}$ * & Undetermined & $\mathrm{CHN}$ & [295] \\
\hline racemosin $(286) /$ alga & Alkaloid $\mathrm{g}$ & PTP1B inhibition & $5.9 \mu \mathrm{M}$ & Undetermined & $\mathrm{CHN}$ & [296] \\
\hline sarcoehrendin B (287)/soft coral & Polyketide ${ }^{\mathrm{e}}$ & PDE4 inhibition & $3.7 \mu \mathrm{M}$ & Undetermined & $\mathrm{CHN}$ & [297] \\
\hline sarsolilide A (288)/soft coral & Terpenoid $^{\mathrm{f}}$ & PTP1B inhibition & $6.8 \mu \mathrm{M}$ & Undetermined & CHN, HUN & [298] \\
\hline $\begin{array}{l}\text { Stachybotry sp. xanthone } \\
\text { (289)/fungus }\end{array}$ & Polyketide ${ }^{\mathrm{e}}$ & COX-2 inhibition & $8.9 \mu \mathrm{M}$ & Undetermined & $\mathrm{CHN}$ & [299] \\
\hline S. thunbergii alkapolyene (290)/alga & Polyketide ${ }^{\mathrm{e}}$ & Soybean LOX inhibition & $5 \mu \mathrm{M}$ & Undetermined & JPN, S. KOR & [300] \\
\hline shinorine (291)/alga & Alkaloid g & C. histolyticum collagenase inhibition & $104 \mu \mathrm{M}$ & Undetermined & AUT & [301] \\
\hline
\end{tabular}


Table 3. Cont.

\begin{tabular}{|c|c|c|c|c|c|c|}
\hline Compound/Organism ${ }^{a}$ & Chemistry & Pharmacological Activity ${ }^{\mathrm{i}}$ & $\mathrm{IC}_{50} \mathrm{~b}$ & MMOA $^{\mathrm{c}}$ & Country ${ }^{d}$ & References \\
\hline sinularone D (292)/soft coral & Polyketide $^{\mathrm{e}}$ & NF- $\mathrm{KB}$ inhibition & $10 \mu \mathrm{g} / \mathrm{mL}^{*}$ & Undetermined & $\mathrm{CHN}$ & [302] \\
\hline $\begin{array}{l}N \text {-(2-benzenepropanoic acid) } \\
\text { stachybotrylactam (293)/fungus }\end{array}$ & Alkaloid $\mathrm{g}$ & Triglyceride and cholesterol inhibition & $10 \mu \mathrm{M} *$ & Undetermined & CHN, DEU & [303] \\
\hline $\begin{array}{l}\text { strongylophorine-13/-14 } \\
\text { (294)/sponge }\end{array}$ & Terpenoid $^{\mathrm{f}}$ & Hu proteasome $20 \mathrm{~S}$ inhibition & $2.1 \mu \mathrm{M}$ & Undetermined & JPN & [304] \\
\hline swinhoeisterol A (295)/sponge & Terpenoid $^{\mathrm{f}}$ & (h)P300 acetyltransferase inhibition & $2.7 \mu \mathrm{M}$ & Undetermined & ITA, CHN, USA & [305] \\
\hline thunberol (296)/alga & Terpenoid $^{\mathrm{f}}$ & PTP1B inhibition & $2.24 \mu \mathrm{g} / \mathrm{mL}$ & Undetermined & $\mathrm{CHN}$ & [306] \\
\hline xestosaprol O (297)/sponge & Terpenoid $^{\mathrm{f}}$ & IDO1 inhibition & $4 \mu \mathrm{M}$ & Undetermined & CAN, NLD & [307] \\
\hline urupocidin A (298)/sponge & Alkaloid $\mathrm{g}$ & iNOS expression induction & $10 \mu \mathrm{M}$ * & Undetermined & RUS, TWN & [308] \\
\hline variabine B (299)/sponge & Alkaloid $\mathrm{g}$ & $\begin{array}{l}\text { Proteasome-chymotrypsin-like activity } \\
\text { inhibition }\end{array}$ & $4 \mu \mathrm{g} / \mathrm{mL}$ & Undetermined & IDN, JPN, NLD & [309] \\
\hline yoshinone A (300)/cyanobacterium & Polyketide ${ }^{\mathrm{e}}$ & Triglyceride inhibition & $0.4 \mu \mathrm{M}$ & Undetermined & JPN & [310] \\
\hline
\end{tabular}

a Organism, Kingdom Animalia: ascidian (Phylum Chordata), soft corals, sea whips, and sea anemone (Phylum Cnidaria), dinoflagellates (Phylum Dinoflagellata), sea urchin (Phylum Echinodermata), sponge (Phylum Porifera); Kingdom Fungi: fungus; Kingdom Plantae: alga; Kingdom Monera: bacterium; ${ }^{\mathrm{b}} \mathrm{IC}_{50}$ : concentration of a compound required for $50 \%$ inhibition in vitro *: estimated IC $50: * * \mathrm{Ki}^{*} * * *$ in vivo study: ${ }^{\mathrm{c}}$ MMOA: molecular mechanism of action. ${ }^{\mathrm{d}}$ Country: AUS: Australia; AUT: Austria; BEL: Belgium; BRA: Brazil: CAN: Canada; CHE: Switzerland; CHN: China; DEU: Germany; EGY: Egypt; FRA: France; ESP: Spain; GBR: United Kingdom; HUN: Hungary; IDN: Indonesia; ISR: Israel; ITA: Italy; IPN: Japan; NLD: The Netherlands; NZL: New Zealand; PYF: French Polynesia; RUS: Russian Federation; SAU: Saudi Arabia; S. KOR: South Korea; TWN: Taiwan; VNM: Vietnam; Chemistry: ${ }^{2}$ Polyketide; ${ }^{\mathrm{f}}$ Terpene; ${ }^{\mathrm{g}}$ Nitrogen-containing compound; ${ }^{\mathrm{h}}$ shikimate; Abbreviations: ACAT: acyl-CoA:cholesterol acyl-transferase; CB: cannabinoid; CDK: cyclin-dependent kinase; COX-2: cyclooxygenase 2; CK1: casein kinase 1; CypD: cyclophilin D; DDYRK: dual-specificity, tyrosine phosphorylation regulated kinase; DPHC: diphlorethohydroxycarmalol; eNOS: endothelial nitric oxide synthase; ERK: extracellular signal-regulated kinase; GAPDH: D-glyceraldehyde-3-phosphate dehydrogenase; GSK3 $\beta$ : glycogen synthase kinase 3; HASMC: human aortic smooth muscle cells; HCAN1: human calpain 1 protease; HCV: hepatitis C virus; hENO1: human alpha-enolase; hu: human; HO-1: hemeoxygenase-1; IDO1: indoleamine 2, 3 dioxygenase; IL: interleukin; iNOS: inducible nitric oxide synthase; LOX: lipoxygenase; NF-kB: nuclear factor kappa-light-chain-enhancer of activated B cells; NO: nitric oxide; mPTP: mitochondrial permeability transition pore; PDGF: platelet-derived growth factor; PDE4: phosphodiesterase 4; PPAR: peroxisome proliferator-activated receptor; PTP1B: protein tyrosine phosphatase 1B; PXR: pregnane-X-receptor; ROS: reactive oxygen species; SERCA2A: SR Ca ${ }^{2+}$ ATPase 2A; TLR5: Toll-like receptor 5; TDP-43: trans-activation response DNA-binding protein of $43 \mathrm{kDa}$; UVB: ultraviolet B; V-ATPase: vacuolar-type $\mathrm{H}^{+}$-ATPase; VEGF: vascular endothelial growth factor. 


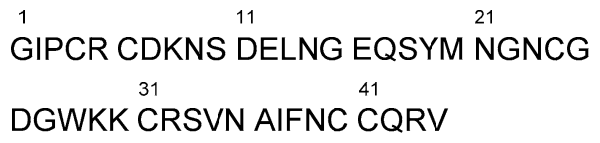

AdE-1 (219)<smiles>C=CCC/C=C/C=C(\C)CC(=C)/C=C(\C)CC[C@@H](O)C(=C)C[C@H]1O[C@H](C)C[C@H]1O</smiles>

amphirionin-4 (221)<smiles>CC1=COc2c3oc(c4c(O)cc(O)c(-c5c(O)cc(O)c6c5Oc5c(O)cc(O)c(Oc7cc(O)cc(O)c7)c5Oc5c(O)cc(O)c(Oc7cc(O)cc(O)c7)c5O6)c4oc2c(O)cc3O)=CC(O)=C1</smiles>

DPHC (227)<smiles>COC1=CC2=CC=Nc3ccc(OC)c(c31)N2</smiles>

aaptamine (220)<smiles>[R]c1cc(CCNC(=O)/C(Cc2cc(Br)c(Oc3cc(C/C(=N/O)C(=O)NCCc4cc(Br)c(O)c(C/C(=N/O)C(=O)NCCc5cc(Br)c(O)c(OCc6cc(Br)cc(Br)c6O)c5)c4)cc(Br)c3Br)c(Br)c2)=N/O)cc([R])c1O</smiles>

bastadin 6 (222) $\mathrm{R}=\mathrm{Br}$ bastadin $16(\mathbf{2 2 3}) \mathrm{R}=\mathrm{H}$

(-)-chlorizidine A (225)<smiles>CC(=O)CCS(=O)(=O)CCO</smiles>

dihydroaustrasulfone alcohol (226)<smiles>Oc1cc(O)cc(Oc2c(O)cc(O)c3c2Oc2c(O)cc(O)cc2O3)c1</smiles>

eckol (228)

Figure 3. Cont. 


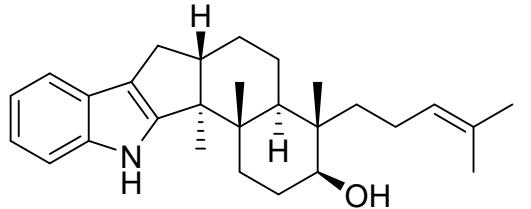

emindole SB (229)<smiles>CC(C)=CCC/C(C)=C/CC/C(C)=C/CC1=CC(=O)C(C)=CC1=O</smiles>

farnesylquinone (230)<smiles>CC(C)=CCC/C(C)=C/CC[C@@]1(C)Cc2c(O)cc3c(c2O1)CN(CCC[C@H](C(=O)O)N1Cc2c(cc(O)c4c2O[C@](C)(CC/C=C(\C)CCC=C(C)C)C(=O)C4=O)C[C@@H]1O)[C@@H]3O</smiles>

FGFC1 (231)<smiles>CCCCC(O)/C=C(C)/C=C/C=C\C(=O)N1CCCC1=O</smiles>

formosusin A (232)<smiles>Oc1cc(O)c(Oc2cc(O)cc(O)c2Oc2cc(O)cc(O)c2-c2c(O)cc(O)cc2O)c(O)c1</smiles><smiles>O=C(O)c1cc(O)c(O)c(O)c1</smiles>

gallic acid (234)

fucodiphlorethol G (233)<smiles>CCC(C)[C@H](C(=O)O[C@H](CC(C)C)C(=O)N[C@@H](CC(C)C)C(=O)N[C@@H](C)/C=C/C(=O)N1C(=O)C=C(OC)[C@H]1C)N(C)C</smiles>

gallinamide A (235)<smiles>CC(=O)O[C@H]1OC2OC3OC(=O)/C(=C\CC4=CC(C)(C)CCC4)C3C2[C@H]1OC(C)C</smiles>

gracilin $\mathrm{H}$ (238)<smiles>NC[C@@H](Cl)[C@H](O)c1c[nH]c(N)n1</smiles>

girolline (236)

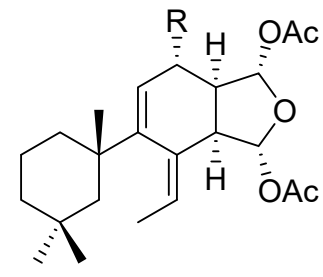

gracilin $\mathrm{A}(237) \mathrm{R}=\mathrm{H}$ gracilin $\mathrm{L}$ (239) $\mathrm{R}=\mathrm{OH}$

Figure 3. Cont. 


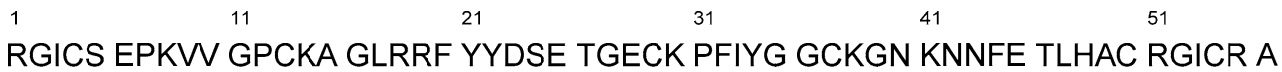
H. crispa polypeptide $\mathbf{2 4 0}$

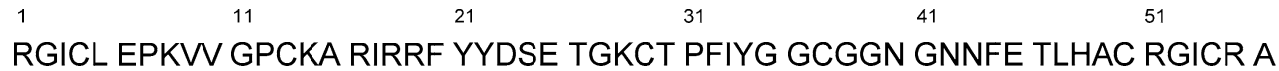
H. crispa polypeptide 241<smiles>CO[C@H]1O[C@@H](O)[C@H]2C1=CC[C@@H]1[C@@H]2CC[C@H]2[C@@H](C)CCC[C@]21C</smiles>

Hyrtios sp. sesterterpene 242<smiles>C=C(C)C[C@H](OC)[C@@H](O)C(=O)N[C@@H](OC)[C@@H]1C[C@@H](O)C(C)(C)[C@@H](C[C@H](O)[C@H](C)[C@H]2Cc3c(C)c(O)cc(O)c3C(=O)O2)O1</smiles>

irciniastatin A (243)<smiles>CO[C@@H]1/C=C/C(C)=C\CC[C@@H](OC)/C=C(C)/C=C/[C@H](C)/C=C/C(=O)O[C@H](/C(C)=C/C=C(\C)CNC(=O)[C@H](COS(=O)(=O)O[Na])NC=O)[C@@H](C)/C=C/C=C/C1</smiles>

iejimalide C (244)<smiles>CSc1c(Br)[nH]c2cc(Br)c(Br)c(Br)c12</smiles>

Laurencia sp. indole 245<smiles>O=C(O[C]1O[C@H](COC(=O)c2ccc(O)cc2)[C@H](O)[C@H]1O)C1=CC=CC=[N+]1</smiles>

neopetroside A (246)

Figure 3. Cont. 


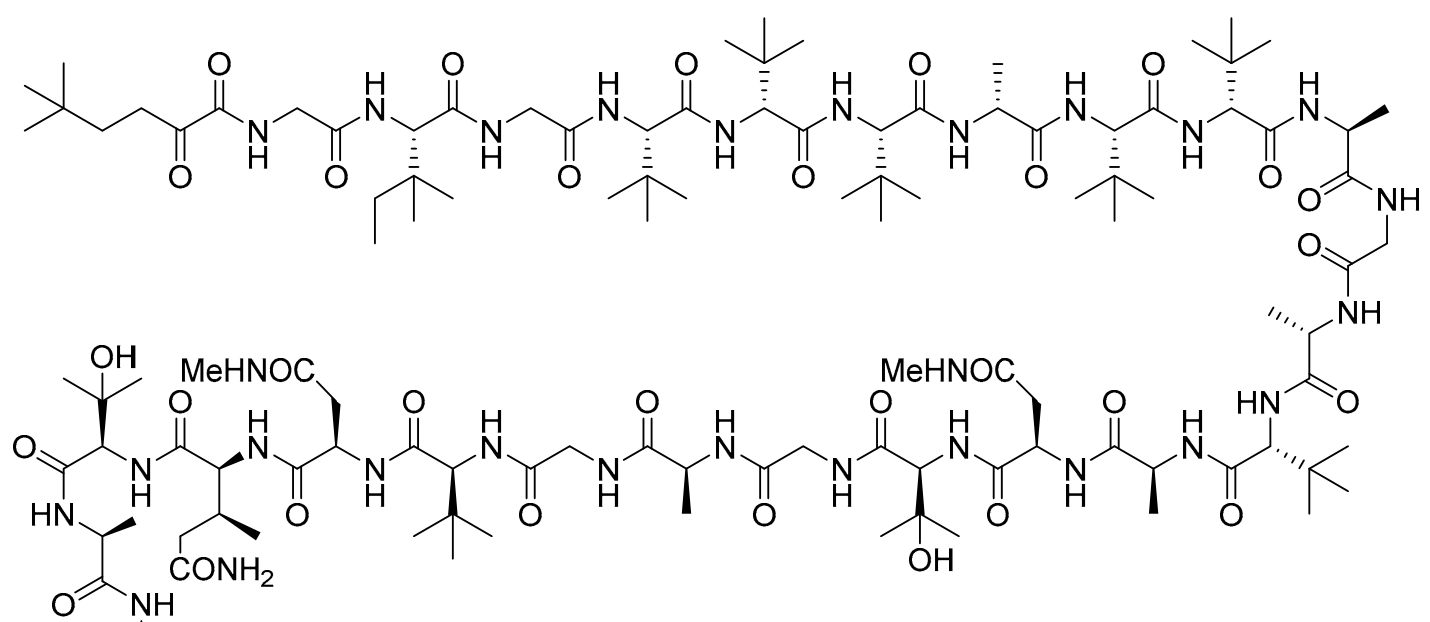

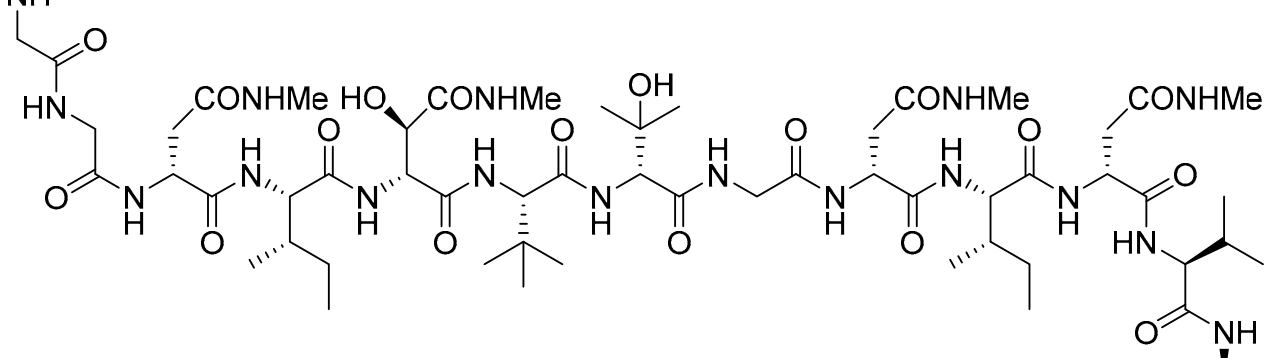

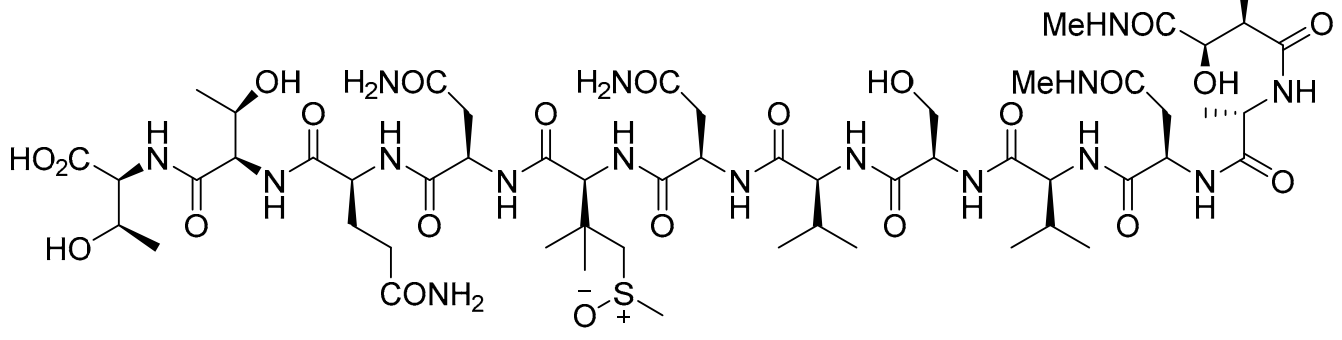

polytheonamide B (247)<smiles>CC1=C[C@H](O)CC(C)(C)[C@H]1/C=C/C(C)=C/C=C/C(C)=C/C=C/C=C(C)/C=C/C=C(\CO)C(=O)CC1=C(C)C[C@@H](O)CC1(C)C</smiles>

siphonaxanthin (248)

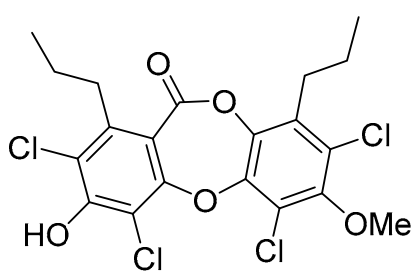

spiromastixone L (249)

Figure 3. Cont. 
<smiles>CCCCCCC/C=C\CC(=O)N[C@H](Cc1ccc(O)cc1)C(=O)NC(C(=O)N[C@H](/C=C/C(=O)NC(C(=O)OCC(Cc1ccc(O)cc1)C(C)C)C(C)C)C(=O)O)C(C)C</smiles>

thalassospiramide C (250)

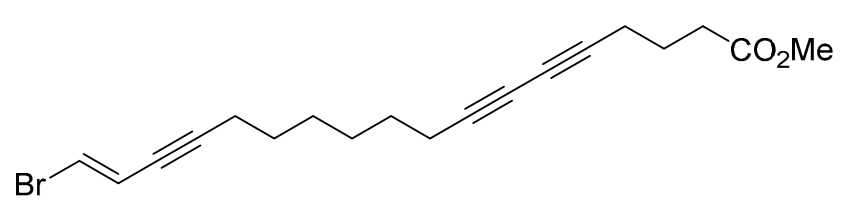

X. testudinarina lipid $\mathbf{2 5 2}$

事

ahpatinin Ac (254)<smiles>COc1c(I)cc(/C=C/C(=O)NCCc2ccccc2)cc1I</smiles>

apliamide D (258)

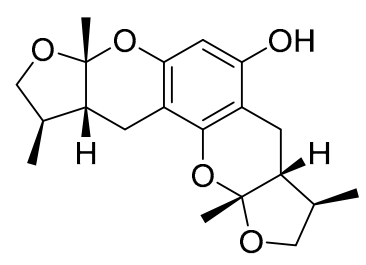

xyloketal B (251)

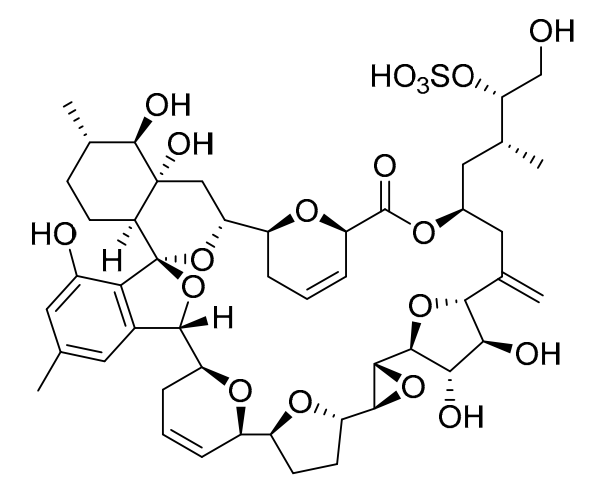

acuminolide A (253)<smiles>[R2]Oc1cc(O)c2c(=O)oc3cc([R20])cc(C)c3c2c1</smiles>

alternariol derivatives

$255 \mathrm{R}=\mathrm{SO}_{3} \mathrm{H}, \mathrm{R}^{\prime}=\mathrm{Me}$

$256 \mathrm{R}=\mathrm{H}, \mathrm{R}^{\prime}=\mathrm{Me}$

$257 \mathrm{R}=\mathrm{R}^{\prime}=\mathrm{H}$

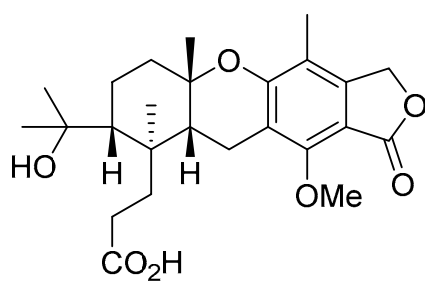

austalide 4 (259)

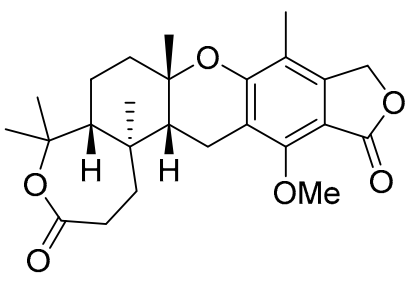

austalide 9 (260)<smiles>CCOC(=O)[C@H](CO)NC(=O)c1cccc(O)c1O</smiles>

axinelline $A$ (261)

Figure 3. Cont. 


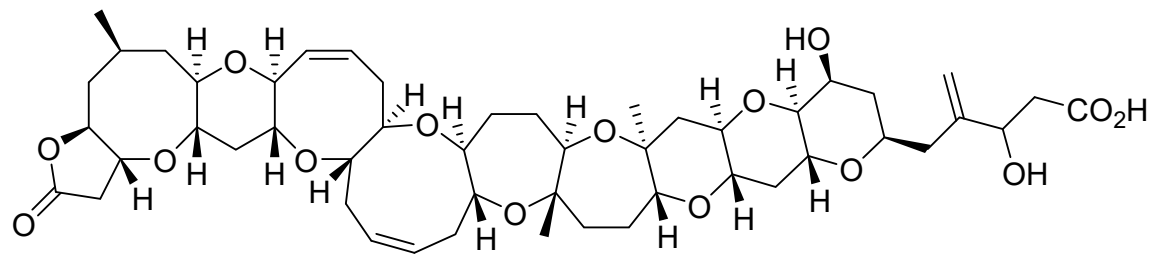

brevisulcatic acid-4 (262)<smiles>CC1=C(CCC(=O)OC/C=C(\C)CCC[C@H](C)CCC[C@H](C)CCCC(C)C)C(=O)NC1=O</smiles>

4',5'-dehydrodiodictyonema A (263)<smiles></smiles>

264

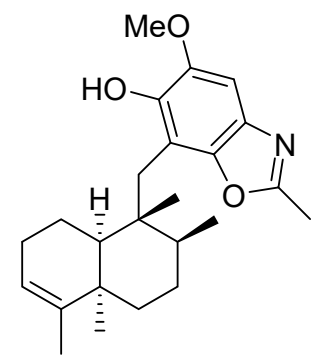

265<smiles>CC(=O)c1cc(O)c(O)c(CC2(C)[C@H]3CCC=C(C)[C@@H]3CC[C@H]2C)c1</smiles>

266

D. metachromia sesquiterpenes

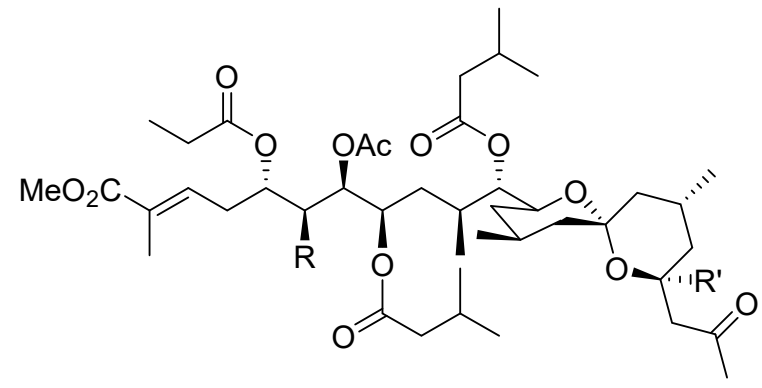

didemnaketal D (267) $\mathrm{R}=\mathrm{CO}_{2} \mathrm{Me}, \mathrm{R}^{\prime}=\mathrm{OAc}$ didemnaketal $\mathrm{E}(\mathbf{2 6 8}) \quad \mathrm{R}=\mathrm{CO}_{2} \mathrm{Et}, \mathrm{R}^{\prime}=\mathrm{OH}$<smiles>C=C1CCC[C@H]2Cc3cc(O)ccc3OC(C)(C)[C@@H]12</smiles>

dysiquinol D (269)<smiles>C[C@]12CCC(=O)c3coc(c31)C(=O)c1cc3c(O)ccc(O[R6]([O-])([O-])O[Na])c3cc12</smiles>

halenaquinol sulfate $(\mathbf{2 7 0})$<smiles>C[C@]12CCC(=O)c3c(CCO)oc(c31)C(=O)c1cc3c(cc12)C(=O)C=CC3=O</smiles>

1-hydroxyethylhalenaquinone (271)

Figure 3. Cont. 
<smiles>[R]c1[nH]c2c(c1[R])C(=C1NC(N)=NC1=O)CCNC2=O</smiles>

hymenialdisine derivatives<smiles>NC1=NC(=O)C(=C2CCNC(=O)c3[nH]c(Br)cc32)N1</smiles>

hymenialdisine (275)

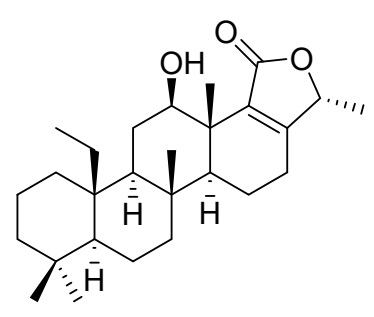

hyattellactone $\mathrm{A}$ (276)

$272 \mathrm{R}^{\prime}=\mathrm{R}^{\prime \prime}=\mathrm{H}$

$273 \mathrm{R}^{\prime}=\mathrm{Br}, \mathrm{R}^{\prime \prime}=\mathrm{H}$

$274 \mathrm{R}^{\prime}=\mathrm{R}^{\prime \prime}=\mathrm{Br}$<smiles>CC(C)=CCC/C(C)=C/CC/C(C)=C/CCC1=CC[C@H]2O[C@H]1NC=C2C=O</smiles><smiles>COc1c(Br)cc(/C=C/C(=O)NCCCNCCCCNCCCN)cc1Br</smiles>

ianthelliformisamine A (278)<smiles>C=C(C)[C@H](/C=C/[C@@H](C)[C@H]1CC[C@H]2C3=CC(=O)O[C@@]3(OC)CC[C@@]21C)CC</smiles>

incisterol A5 (279)

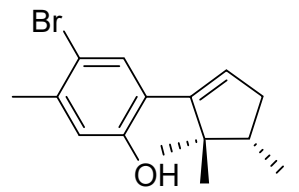

L. okamurai terpenoid 282<smiles>CC[C@H](CC[C@@H](C)[C@H]1CC[C@H]2C3=CC(=O)OC3(OC)CC[C@@]21C)C(C)C</smiles>

incisterol A6 (280)

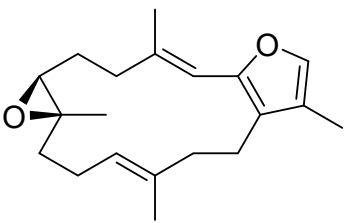

L. crassum cembranoid $\mathbf{2 8 1}$

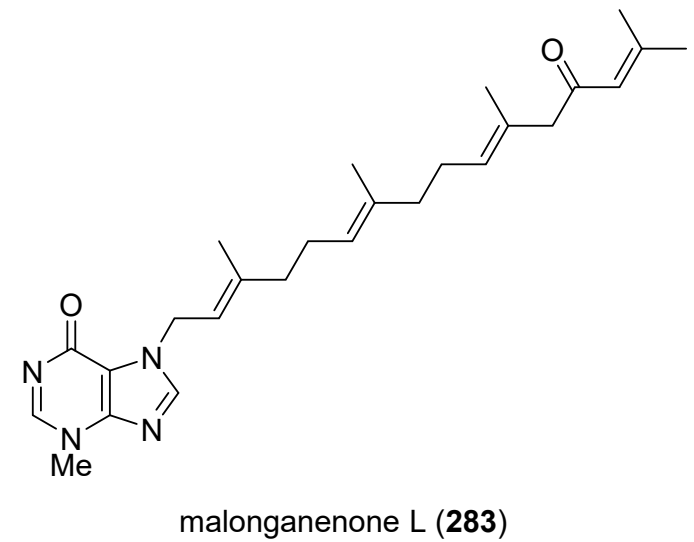

Figure 3. Cont. 
<smiles>C=C1CC[C@@]2(O)[C@@H](CC2(C)C)/C(CO)=C/[C@H](O)[C@@H]1NC(=O)/C=C(\C)CCO</smiles>

punctaporonin K (284)<smiles>CC(C)(C)N1C(=O)[C@@H](O)[C@H](O)c2cn(c3ccccc23)C(=O)c2ccccc2NC(=O)[C@@H]2CCCN21</smiles>

Ác O<smiles>COC(=O)/C1=C/c2c([nH]c3ccccc23)C(=O)[C@@H](O)c2c1[nH]c1ccccc21</smiles>

racemosin C (286)

psychrophilin G (285)

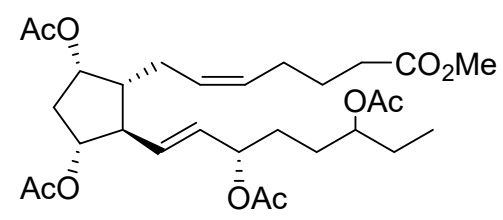

sarcoehrendin B (287)

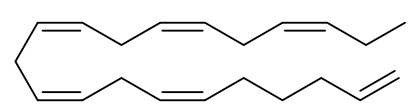

S. thunbergii alkapolyene $\mathbf{2 9 0}$

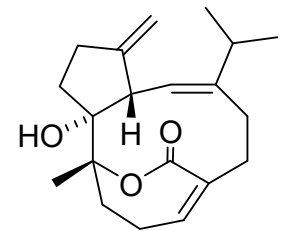

sarsolilide A (288)<smiles>COc1cc(C)c(C(=O)c2c(O)cc(OC)c(Cl)c2O)c(O)c1</smiles>

Stachybotry sp. xanthone 289<smiles>CCCC[C@H]1C(=O)C(C)=C(C)[C@]12CCC(=O)O2</smiles>

sinularone D (292) shinorine (291)<smiles>COC1=C(NCC(=O)O)C[C@](O)(CO)C/C1=N/[C@@H](CO)C(=O)O</smiles><smiles></smiles>

$\mathrm{N}$-(2-benzenepropanoic acid) stachybotrylactam (293)<smiles>C=C1[C@H](O)CC[C@]2(C)C3=C4[C@H](CCC3=O)C([C@H](C)CC[C@H](C)C(C)C)CC[C@@]4(C)[C@@H]12</smiles>
swinhoeisterol A (295)

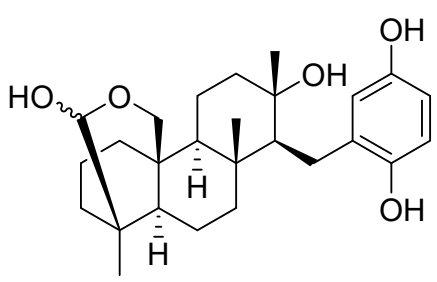

strongylophorine-13/-14 (294)<smiles>C/C=C(\CC[C@@H](C)[C@H]1CCC2C3CC=C4C(=O)C(O)=CC[C@]4(C)C3CC[C@]21C)C(C)C</smiles>

thunberol (296)

Figure 3. Cont. 
<smiles>C[C@]12CC[C@@H](O)CC1=C(O)C(=O)c1cc3c(cc12)C(=O)C1=C(C3=O)S(=O)(=O)CCN1</smiles>

xestosaprol O (297)<smiles>CCC/C=C\CC1NC(=[NH2+])N2C(=C1C(=O)OCCCCN(O)C(=N)N)CC[C@@H]2C[C@@H](O)CC/C=C/CCC</smiles>

urupocidin $A$ (298)<smiles>COC(=O)c1cc2c(cn1)[nH]c1ccc(O)cc12</smiles>

variabine B (299)<smiles>COc1oc(C/C=C(\C)CCC(C)/C(C)=C/C(C)O)c(C)c(=O)c1C</smiles>

yoshinone $A(\mathbf{3 0 0})$

Figure 3. Marine pharmacology in 2014-2015: marine compounds with miscellaneous mechanisms of action.

\section{Reviews on Marine Pharmacology and Pharmaceuticals}

In 2014-2015, several reviews covered general and/or specific areas of marine preclinical pharmacology: (a) Marine pharmacology and marine pharmaceuticals: new marine natural products and relevant biological activities published in 2014 and 2015 [311,312]; marine peptides, bioactivities and applications [313]; bioactive terpenes from marine-derived fungi [314]; bioactive marine natural products from actinobacteria with unique chemical structures [315]; Baltic cyanobacteria as a source of biologically active compounds [316]; biological targets of marine cyanobacteria natural products [317]; marine mussels as a source for bioactive compounds for human health [318]; pharmacological potential of cephalopod ink in drug discovery [319]; pharmacologically active Brazilian octocorals [320]; bioactive natural products isolated from marine microorganisms from Brazil [321]; statistical analysis of marine natural product bioactivity from 1985-2012 [322]; metagenomics and marine natural products drug discovery [323]; new horizons for selected marine natural products as drug leads [324]; marine-sourced agents in clinical and late preclinical development [325]; the global marine pharmaceutical pipeline in 2019: approved compounds and those in Phase I, II, and III of clinical development https://www.midwestern.edu/departments/marinepharmacology.xml. (b) Antimicrobial marine pharmacology: biophysical properties of anti-lipopolysaccharide antimicrobial peptides isolated from marine fish [326]; marine peptides and their anti-microbial activities [327]; marine membrane-active peptides as antimicrobials [328]; marine fungi antibacterial compounds [329]. (c) Antiviral marine pharmacology: marine natural products with antiviral potential [330]; antiviral activity in marine fungi-derived natural products [331]. (d) Antiprotozoal and antimalarial marine pharmacology: antiprotozoal activity in marine natural products isolated from marine algae [332]; marine indole alkaloids as potential leads for antiprotozoal drugs [333]; antimalarial potency of the manzamine $\beta$-carboline alkaloids [334]. (e) Immuno- and anti-inflammatory marine pharmacology: marine diterpenoids as potential anti-inflammatory agents [335]; microalgae bioactive compounds for inflammation and cancer [336]. (f) Cardiovascular and antidiabetic marine pharmacology: marine-derived natural products as a source of cardiovascular protective agents [337]; antioxidant phlorotannins derived from marine algae [338]; antioxidant carotenoids isolated from marine Gram-positive bacteria [339]; brown alga-derived fucoxanthin for diabetes therapy [340]; bioactive compounds from seaweed for diabetes [341]. (g) Nervous system marine pharmacology: astaxanthin as a potential neuroprotective agent [342]; origin, distribution, toxicity, and therapeutic uses of the marine neurotoxin tetrodotoxin [343]; marine natural products with neuroprotective activity [344]; 
marine-terpenoid gracilins as promising compounds for Alzheimer's disease [345]; new marine drugs for Alzheimer's disease treatment [346]. (h) Miscellaneous molecular targets and uses: matrix metalloproteinase inhibitors isolated from edible marine algae [347]; marine natural products that targeting apoptosis signaling pathways [348]; scytonemin and emerging biomedical applications [349]; antiobesity effects of the carotenoid fucoxanthin [350]; therapeutic potential of astaxanthin [351]; pharmacological properties of marine coumarins [352].

\section{Conclusions}

The current marine pharmacology 2014-2015 review is a sequel to the marine preclinical pharmacology pipeline review series initiated in 1998 [1-9], and consolidates the peer-reviewed preclinical marine pharmacological literature published during 2014-2015. The global preclinical marine pharmacology research involved chemists and pharmacologists from 43 countries, namely, Australia, Austria, Bangladesh, Belgium, Brazil, Canada, China, Colombia, Costa Rica, Cuba, Denmark, Egypt, Finland, France, French Polynesia, Germany, Hungary, India, Indonesia, Ireland, Israel, Italy, Japan, Malaysia, Mexico, the Netherlands, New Zealand, Norway, Papua New Guinea, Portugal, Russian Federation, Saudi Arabia, Singapore, South Africa, South Korea, Spain, Sri Lanka, Switzerland, Taiwan, Thailand, United Kingdom, Vietnam, and the United States. Thus, during 2014-2015, the marine preclinical pharmaceutical pipeline continued to provide novel pharmacology that provided novel leads for the marine clinical pharmaceutical pipeline. As shown at the global marine pharmaceutical pipeline website, https://www.midwestern.edu/departments/marinepharmacology.xml, there are currently 9 approved marine-derived pharmaceuticals, and an additional 31 compounds are either in Phase I, II, and III of clinical pharmaceutical development.

Acknowledgments: We thank the contributions of Kelly Le, Pharm. D., and Jefferson Trieu, Pharm. D., both graduates from the Chicago College of Pharmacy, Midwestern University for marine pharmacology literature retrieval, and Colleen Bannon, Midwestern University Library, for Endnote database assistance. In particular, we wish to acknowledge Mary Hall's tireless and careful review of the preclinical pharmacological data presented in 805 articles that were retrieved from the global marine pharmacology literature for the 2014-2015 period. We also thank the secretarial assistance of Victoria Sears and Laura Phelps from the Pharmacology Department, College of Graduate Studies. We gratefully acknowledge financial support from Midwestern University to A.M.S.M.; and NIH-SC1 Award (Grant 1SC1GM086271-01A1) of the University of Puerto Rico to A.D.R., and a grant from Regione Campania-POR Campania FESR 2014/2020 “Combattere la resistenza tumorale: piattaforma integrata multidisciplinare per un approccio tecnologico innovativo alle oncoterapie-Campania Oncoterapie" (Project N. B61G18000470007) to O.T.S. The content of this review is solely the responsibility of the authors and does not necessarily represent the official views of the NIH.

Conflicts of Interest: The authors declare no conflict of interest.

\section{References}

1. Mayer, A.M.S.; Lehmann, V.K.B. Marine pharmacology in 1998: Marine compounds with antibacterial, anticoagulant, antifungal, anti-inflammatory, anthelmintic, antiplatelet, antiprotozoal, and antiviral activities; with actions on the cardiovascular, endocrine, immune, and nervous systems; and other miscellaneous mechanisms of action. Pharmacologist 2000, 42, 62-69.

2. Mayer, A.M.; Hamann, M.T. Marine pharmacology in 1999: Compounds with antibacterial, anticoagulant, antifungal, anthelmintic, anti-inflammatory, antiplatelet, antiprotozoal and antiviral activities affecting the cardiovascular, endocrine, immune and nervous systems, and other miscellaneous mechanisms of action. Comp. Biochem. Physiol. Part C Pharmacol. Toxicol. Endocrinol. 2002, 132, 315-339.

3. Mayer, A.M.S.; Hamann, M.T. Marine pharmacology in 2000: Marine compounds with antibacterial, anticoagulant, antifungal, anti-inflammatory, antimalarial, antiplatelet, antituberculosis, and antiviral activities; affecting the cardiovascular, immune, and nervous systems and other miscellaneous mechanisms of action. Mar. Biotechnol. 2004, 6, 37-52. [PubMed] 
4. Mayer, A.M.; Hamann, M.T. Marine pharmacology in 2001-2: Marine compounds with anthelmintic, antibacterial, anticoagulant, antidiabetic, antifungal, anti-inflammatory, antimalarial, antiplatelet, antiprotozoal, antituberculosis, and antiviral activities; affecting the cardiovascular, immune and nervous systems and other miscellaneous mechanisms of action. Comp. Biochem. Physiol. C. Pharmacol. Toxicol. Endocrinol. 2005, 140, 265-286.

5. Mayer, A.M.; Rodriguez, A.D.; Berlinck, R.G.; Hamann, M.T. Marine pharmacology in 2003-4: Marine compounds with anthelmintic antibacterial, anticoagulant, antifungal, anti-inflammatory, antimalarial, antiplatelet, antiprotozoal, antituberculosis, and antiviral activities; affecting the cardiovascular, immune and nervous systems, and other miscellaneous mechanisms of action. Comp. Biochem. Physiol. Part C Pharmacol. Toxicol. Endocrinol. 2007, 145, 553-581.

6. Mayer, A.M.; Rodriguez, A.D.; Berlinck, R.G.; Hamann, M.T. Marine pharmacology in 2005-6: Marine compounds with anthelmintic, antibacterial, anticoagulant, antifungal, anti-inflammatory, antimalarial, antiprotozoal, antituberculosis, and antiviral activities; affecting the cardiovascular, immune and nervous systems, and other miscellaneous mechanisms of action. Biochim. Biophys. Acta Gen. Subj. 2009, 1790, $283-308$.

7. Mayer, A.M.; Rodriguez, A.D.; Berlinck, R.G.; Fusetani, N. Marine pharmacology in 2007-8: Marine compounds with antibacterial, anticoagulant, antifungal, anti-inflammatory, antimalarial, antiprotozoal, antituberculosis, and antiviral activities; affecting the immune and nervous system, and other miscellaneous mechanisms of action. Comp. Biochem. Physiol. Part C Pharmacol. Toxicol. Endocrinol. 2011, 153, 191-222.

8. Mayer, A.M.; Rodriguez, A.D.; Taglialatela-Scafati, O.; Fusetani, N. Marine Pharmacology in 2009-2011: Marine Compounds with Antibacterial, Antidiabetic, Antifungal, Anti-Inflammatory, Antiprotozoal, Antituberculosis, and Antiviral Activities; Affecting the Immune and Nervous Systems, and other Miscellaneous Mechanisms of Action. Mar. Drugs 2013, 11, 2510-2573.

9. Mayer, A.M.S.; Rodriguez, A.D.; Taglialatela-Scafati, O.; Fusetani, N. Marine Pharmacology in 2012-2013: Marine Compounds with Antibacterial, Antidiabetic, Antifungal, Anti-Inflammatory, Antiprotozoal, Antituberculosis, and Antiviral Activities; Affecting the Immune and Nervous Systems, and Other Miscellaneous Mechanisms of Action. Mar. Drugs 2017, 15, 273.

10. Schmitz, F.J.; Bowden, B.F.; Toth, S.I. Antitumor and Cytotoxic Compounds from Marine Organisms. In Marine Biotechnology, Pharmaceutical and Bioactive Natural Products; Attaway, D.H., Zaborsky, O.R., Eds.; Plenum Press: New York, NY, USA; London, UK, 1993; Volume 1, pp. 197-308.

11. Ochoa, J.L.; Bray, W.M.; Lokey, R.S.; Linington, R.G. Phenotype-Guided Natural Products Discovery Using Cytological Profiling. J. Nat. Prod. 2015, 78, 2242-2248. [CrossRef]

12. Quintana, J.; Brango-Vanegas, J.; Costa, G.M.; Castellanos, L.; Arevalo, C.; Duque, C. Marine organisms as source of extracts to disrupt bacterial communication: Bioguided isolation and identification of quorum sensing inhibitors from Ircinia felix. Rev. Brasil. Farmacogn. 2015, 25, 199-207. [CrossRef]

13. Henriquez, M.; Vergara, K.; Norambuena, J.; Beiza, A.; Maza, F.; Ubilla, P.; Araya, I.; Chavez, R.; San-Martin, A.; Darias, J.; et al. Diversity of cultivable fungi associated with Antarctic marine sponges and screening for their antimicrobial, antitumoral and antioxidant potential. World J. Microbiol. Biotechnol. 2014, 30, 65-76. [CrossRef] [PubMed]

14. Rahelivao, M.P.; Gruner, M.; Andriamanantoanina, H.; Andriamihaja, B.; Bauer, I.; Knölker, H.J. Red algae (Rhodophyta) from the coast of Madagascar: Preliminary bioactivity studies and isolation of natural products. Mar. Drugs 2015, 13, 4197-4216. [CrossRef] [PubMed]

15. Chakraborty, K.; Thilakan, B.; Raola, V.K. Polyketide family of novel antibacterial 7-O-methyl-5'-hydroxy-3'-heptenoate-macrolactin from seaweed-associated Bacillus subtilis MTCC 10403. J. Agric. Food Chem. 2014, 62, 12194-12208. [CrossRef] [PubMed]

16. Shanthi, J.; Senthil, A.; Gopikrishnan, V.; Balagurunathan, R. Characterization of a potential beta-lactamase inhibitory metabolite from a marine Streptomyces sp. PM49 active against multidrug-resistant pathogens. Appl. Biochem. Biotechnol. 2015, 175, 3696-3708. [CrossRef]

17. Pereira, D.M.; Correia-da-Silva, G.; Valentao, P.; Teixeira, N.; Andrade, P.B. Anti-inflammatory effect of unsaturated fatty acids and ergosta-7,22-dien-3-ol from Marthasterias glacialis: Prevention of CHOP-mediated ER-stress and NF-kappaB activation. PLoS ONE 2014, 9, e88341. [CrossRef] [PubMed]

18. Banskota, A.H.; Stefanova, R.; Sperker, S.; Lall, S.; Craigie, J.S.; Hafting, J.T. Lipids isolated from the cultivated red alga Chondrus crispus inhibit nitric oxide production. J. Appl. Phycol. 2014, 26, 1565-1571. [CrossRef] 
19. Ju, B.; Chen, B.; Zhang, X.; Han, C.; Jiang, A. Purification and characterization of bioactive compounds from Styela clava. J. Chem. 2014, 2014, 525141. [CrossRef]

20. Abou-Hussein, D.R.; Badr, J.M.; Youssef, D.T. Dragmacidoside: A new nucleoside from the Red sea sponge Dragmacidon coccinea. Nat. Prod. Res. 2014, 28, 1134-1141. [CrossRef]

21. Deghrigue, M.; Festa, C.; Ghribi, L.; D'Auria, M.V.; De, M.S.; Ben, J.H.; Bouraoui, A. Anti-inflammatory and analgesic activities with gastroprotective effect of semi-purified fractions and isolation of pure compounds from Mediterranean gorgonian Eunicella singularis. Asian Pac. J. Trop. Med. 2015, 8, 606-611. [CrossRef]

22. Oliveira, A.P.; Lobo-da-Cunha, A.; Taveira, M.; Ferreira, M.; Valentao, P.; Andrade, P.B. Digestive gland from Aplysia depilans Gmelin: Leads for inflammation treatment. Molecules 2015, 20, 15766-15780. [CrossRef] [PubMed]

23. Kong, C.S.; Kim, H.; Seo, Y. Edible brown alga Ecklonia cava derived phlorotannin-induced anti-adipogenic activity in vitro. J. Food Biochem. 2015, 39, 1-10. [CrossRef]

24. Rodriguez, R.A.; Barrios, S.D.; Kawamata, Y.; Su, S.; Smith, P.A.; Steed, T.C.; Romesberg, F.E.; Baran, P.S. Axinellamines as broad-spectrum antibacterial agents: Scalable synthesis and biology. J. Am. Chem. Soc. 2014, 136, 15403-15413. [CrossRef] [PubMed]

25. Moon, K.; Chung, B.; Shin, Y.; Rheingold, A.L.; Moore, C.E.; Park, S.J.; Park, S.; Lee, S.K.; Oh, K.B.; Shin, J.; et al. Pentacyclic antibiotics from a tidal mud flat-derived actinomycete. J. Nat. Prod. 2015, 78, 524-529. [CrossRef]

26. Wei, L.; Gao, J.; Zhang, S.; Wu, S.; Xie, Z.; Ling, G.; Kuang, Y.Q.; Yang, Y.; Yu, H.; Wang, Y. Identification and characterization of the first cathelicidin from sea snakes with potent antimicrobial and anti-inflammatory activity and special mechanism. J. Biol. Chem. 2015, 290, 16633-16652. [CrossRef]

27. Silva, O.N.; Fensterseifer, I.C.; Rodrigues, E.A.; Holanda, H.H.; Novaes, N.R.; Cunha, J.P.; Rezende, T.M.; Magalhaes, K.G.; Moreno, S.E.; Jeronimo, M.S.; et al. Clavanin A improves outcome of complications from different bacterial infections. Antimicrob. Agents Chemother. 2015, 59, 1620-1626. [CrossRef]

28. Abdelmohsen, U.R.; Cheng, C.; Reimer, A.; Kozjak-Pavlovic, V.; Ibrahim, A.K.; Rudel, T.; Hentschel, U.; Edrada-Ebel, R.; Ahmed, S.A. Antichlamydial sterol from the Red sea sponge Callyspongia aff. implexa. Planta Med. 2015, 81, 382-387. [CrossRef]

29. Pieri, C.; Borselli, D.; Di, G.C.; De, M.M.; Bolla, J.M.; Vidal, N.; Combes, S.; Brunel, J.M. New Ianthelliformisamine derivatives as antibiotic enhancers against resistant Gram-negative bacteria. J. Med. Chem. 2014, 57, 4263-4272. [CrossRef]

30. Huang, H.N.; Pan, C.Y.; Chan, Y.L.; Chen, J.Y.; Wu, C.J. Use of the antimicrobial peptide pardaxin (GE33) to protect against methicillin-resistant Staphylococcus aureus infection in mice with skin injuries. Antimicrob. Agents Chemother. 2014, 58, 1538-1545. [CrossRef]

31. Eom, S.H.; Lee, D.S.; Jung, Y.J.; Park, J.H.; Choi, J.I.; Yim, M.J.; Jeon, J.M.; Kim, H.W.; Son, K.T.; Je, J.Y.; et al. The mechanism of antibacterial activity of phlorofucofuroeckol-A against methicillin-resistant Staphylococcus aureus. Appl. Microbiol. Biotechnol. 2014, 98, 9795-9804. [CrossRef]

32. Hassan, H.M.; Degen, D.; Jang, K.H.; Ebright, R.H.; Fenical, W. Salinamide F, new depsipeptide antibiotic and inhibitor of bacterial RNA polymerase from a marine-derived Streptomyces sp. J. Antibiot. 2015, 68, 206-209. [CrossRef] [PubMed]

33. Pan, C.Y.; Chen, J.C.; Chen, T.L.; Wu, J.L.; Hui, C.F.; Chen, J.Y. Piscidin is highly active against carbapenem-resistant Acinetobacter baumannii and NDM-1-producing Klebsiella pneumonia in a systemic septicaemia infection mouse model. Mar. Drugs 2015, 13, 2287-2305. [CrossRef] [PubMed]

34. Liu, Y.; Li, X.M.; Meng, L.H.; Jiang, W.L.; Xu, G.M.; Huang, C.G.; Wang, B.G. Bisthiodiketopiperazines and acorane sesquiterpenes produced by the marine-derived fungus Penicillium adametzioides AS-53 on different culture media. J. Nat. Prod. 2015, 78, 1294-1299. [CrossRef] [PubMed]

35. Kusama, T.; Tanaka, N.; Sakai, K.; Gonoi, T.; Fromont, J.; Kashiwada, Y.; Kobayashi, J. Agelamadins A and B, dimeric bromopyrrole alkaloids from a marine sponge Agelas sp. Org. Lett. 2014, 16, 3916-3918. [CrossRef]

36. Chen, M.; Wang, K.L.; Liu, M.; She, Z.G.; Wang, C.Y. Bioactive steroid derivatives and butyrolactone derivatives from a gorgonian-derived Aspergillus sp. fungus. Chem. Biodivers. 2015, 12, 1398-1406. [CrossRef]

37. Gomes, N.M.; Bessa, L.J.; Buttachon, S.; Costa, P.M.; Buaruang, J.; Dethoup, T.; Silva, A.M.; Kijjoa, A. Antibacterial and antibiofilm activities of tryptoquivalines and meroditerpenes isolated from the marine-derived fungi Neosartorya paulistensis, N. laciniosa, N. tsunodae, and the soil fungi N. fischeri and N. siamensis. Mar. Drugs 2014, 12, 822-839. [CrossRef] 
38. Zhou, Y.; Debbab, A.; Wray, V.; Lin, W.H.; Schulz, B.; Trepos, R.; Pile, C.; Hellio, C.; Proksch, P.; Aly, A.H. Marine bacterial inhibitors from the sponge-derived fungus Aspergillus sp. Tetrahedron Lett. 2014, 55, 2789-2792. [CrossRef]

39. Meng, L.H.; Liu, Y.; Li, X.M.; Xu, G.M.; Ji, N.Y.; Wang, B.G. Citrifelins A and B, citrinin adducts with a tetracyclic framework from cocultures of marine-derived isolates of Penicillium citrinum and Beauveria felina. J. Nat. Prod. 2015, 78, 2301-2305. [CrossRef]

40. Du, F.Y.; Zhang, P.; Li, X.M.; Li, C.S.; Cui, C.M.; Wang, B.G. Cyclohexadepsipeptides of the isaridin class from the marine-derived fungus Beauveria felina EN-135. J. Nat. Prod. 2014, 77, 1164-1169. [CrossRef]

41. Sun, S.; Canning, C.B.; Bhargava, K.; Sun, X.; Zhu, W.; Zhou, N.; Zhang, Y.; Zhou, K. Polybrominated diphenyl ethers with potent and broad spectrum antimicrobial activity from the marine sponge Dysidea. Bioorg. Med. Chem. Lett. 2015, 25, 2181-2183. [CrossRef]

42. Khanthong, N.; Rukachaisirikul, V.; Phongpaichit, S.; Preedanon, S.; Sakayaroj, J. An antibacterial cytochalasin derivative from the marine-derived fungus Diaporthaceae sp. PSU-SP2/4. Phytochemistry 2014, 10, 5-9. [CrossRef]

43. Pereira, U.A.; Barbosa, L.C.; Maltha, C.R.; Demuner, A.J.; Masood, M.A.; Pimenta, A.L. gamma-alkylidene-gamma-lactones and isobutylpyrrol-2(5H)-ones analogues to rubrolides as inhibitors of biofilm formation by gram-positive and gram-negative bacteria. Bioorg. Med. Chem. Lett. 2014, 24, 1052-1056. [CrossRef] [PubMed]

44. Kim, C.K.; Woo, J.K.; Kim, S.H.; Cho, E.; Lee, Y.J.; Lee, H.S.; Sim, C.J.; Oh, D.C.; Oh, K.B.; Shin, J. Meroterpenoids from a tropical Dysidea sp. sponge. J. Nat. Prod. 2015, 78, 2814-2821. [CrossRef]

45. Jiao, W.H.; Li, J.; Liu, Q.; Xu, T.T.; Shi, G.H.; Yu, H.B.; Yang, F.; Han, B.N.; Li, M.; Lin, H.W. Dysidinoid A, an unusual meroterpenoid with anti-MRSA activity from the South China sea sponge Dysidea sp. Molecules 2014, 19, 18025-18032. [CrossRef]

46. Martinez-Diaz, Y.; Vaneges Laverde, G.; Reina Gamba, L.; Mayorga Wandurraga, H.; Arevalo-Ferro, C.; Ramos Rodriguez, F.; Duque, C.; Hernandez, L.M.C. Biofilm inhibition activity of compounds isolated from two Eunicea species collected at the Caribbean sea. Rev. Brasil. Farmacogn. 2015, 25, 605-611. [CrossRef]

47. Bai, Z.Q.; Lin, X.; Wang, Y.; Wang, J.; Zhou, X.; Yang, B.; Liu, J.; Yang, X.; Wang, Y.; Liu, Y. New phenyl derivatives from endophytic fungus Aspergillus flavipes AIL8 derived of mangrove plant Acanthus ilicifolius. Fitoterapia 2014, 95, 194-202. [CrossRef]

48. Tareq, F.S.; Lee, M.A.; Lee, H.S.; Lee, Y.J.; Lee, J.S.; Hasan, C.M.; Islam, M.T.; Shin, H.J. Non-cytotoxic antifungal agents: Isolation and structures of gageopeptides A-D from a Bacillus strain 109GGC020. J. Agric. Food Chem. 2014, 62, 5565-5572. [CrossRef]

49. Tareq, F.S.; Lee, M.A.; Lee, H.S.; Lee, Y.J.; Lee, J.S.; Hasan, C.M.; Islam, M.T.; Shin, H.J. Gageotetrins A-C, noncytotoxic antimicrobial linear lipopeptides from a marine bacterium Bacillus subtilis. Org. Lett. 2014, 16, 928-931. [CrossRef]

50. Bae, M.; Chung, B.; Oh, K.B.; Shin, J.; Oh, D.C. Hormaomycins B and C: New antibiotic cyclic depsipeptides from a marine mudflat-derived Streptomyces sp. Mar. Drugs 2015, 13, 5187-5200. [CrossRef]

51. Tareq, F.S.; Lee, H.S.; Lee, Y.J.; Lee, J.S.; Shin, H.J. Ieodoglucomide C and Ieodoglycolipid, new glycolipids from a marine-derived bacterium Bacillus licheniformis 09IDYM23. Lipids 2015, 50, 513-519. [CrossRef]

52. Lacret, R.; Oves-Costales, D.; Gomez, C.; Diaz, C.; de la Cruz, M.; Perez-Victoria, I.; Vicente, F.; Genilloud, O.; Reyes, F. New ikarugamycin derivatives with antifungal and antibacterial properties from Streptomyces zhaozhouensis. Mar. Drugs 2015, 13, 128-140. [CrossRef]

53. Kusama, T.; Tanaka, N.; Takahashi-Nakaguchi, A.; Gonoi, T.; Fromont, J.; Kobayashi, J. Bromopyrrole alkaloids from a marine sponge Agelas sp. Chem. Pharm. Bull. 2014, 62, 499-503. [CrossRef]

54. Yang, I.; Choi, H.; Won, D.H.; Nam, S.J.; Kang, H. An antibacterial 9.11-secosterol from a marine sponge Ircinia sp. Bull. Korean Chem. Soc. 2014, 35, 3360-3362. [CrossRef]

55. Yang, I.; Choi, H.; Nam, S.J.; Kang, H. A new 9,11-secosterol with a 1,4-quinone from a Korean marine sponge Ircinia sp. Arch. Pharm. Res. 2015, 38, 1970-1974. [CrossRef]

56. Radwan, M.M.; Wanas, A.S.; Fronczek, F.R.; Jacob, M.R.; Ross, S.A. Polybrominated diphenyl ethers from the marine organisms Lendenfeldia dendyi and Sinularia dura with anti-MRSa activity. Med. Chem. Res. 2015, 24, 3398-3404. [CrossRef]

57. Wu, B.; Wiese, J.; Labes, A.; Kramer, A.; Schmaljohann, R.; Imhoff, J.F. Lindgomycin, an unusual antibiotic polyketide from a marine fungus of the Lindgomycetaceae. Mar. Drugs 2015, 13, 4617-4632. [CrossRef] 
58. Zhou, X.; Huang, H.; Lie, J.; Ju, J. New anti-infective cycloheptadepsipeptide congeners and absolute stereochemistry from the deep sea-derived Streptomyces drozdowiczii SCSIO 10141. Tetrahedron 2014, 70, 7795-7901. [CrossRef]

59. Raju, R.; Khalil, Z.G.; Piggott, A.M.; Blumenthal, A.; Gardiner, D.L.; Skinner-Adams, T.S.; Capon, R.J. Mollemycin A: An antimalarial and antibacterial glyco-hexadepsipeptide-polyketide from an Australian marine-derived Streptomyces sp. (CMB-M0244). Org. Lett. 2014, 16, 1716-1719. [CrossRef]

60. Kamada, T.; Vairappan, C.S. New laurene-type sesquiterpene from Bornean Laurencia nangii. Nat. Prod. Commun. 2015, 10, 843-844. [CrossRef]

61. Guo, W.; Zhang, Z.; Zhu, T.; Gu, Q.; Li, D. Penicyclones A-E, antibacterial polyketides from the deep-sea-derived fungus Penicillium sp. F23-2. J. Nat. Prod. 2015, 78, 2699-2703. [CrossRef]

62. Li, X.; Li, X.M.; Zhang, P.; Wang, B.G. A new phenolic enamide and a new meroterpenoid from marine alga-derived endophytic fungus Penicillium oxalicum EN-290. J Asian Nat. Prod. Res. 2015, 17, 1204-1212. [CrossRef]

63. Hagiwara, K.; Garcia Hernandez, J.E.; Harper, M.K.; Carroll, A.; Motti, C.A.; Awaya, J.; Nguyen, H.Y.; Wright, A.D. Puupehenol, a potent antioxidant antimicrobial meroterpenoid from a Hawaiian deep-water Dactylospongia sp. sponge. J. Nat. Prod. 2015, 78, 325-329. [CrossRef]

64. Hassan, M.H.; Rateb, M.E.; Hetta, M.; Abdelaziz, T.A.; Sleim, M.A.; Jaspars, M.; Mohammed, R. Scalarane sesterterpenes from the Egyptian Red sea sponge Phyllospongia lamellosa. Tetrahedron 2015, 71, 577-583. [CrossRef]

65. Al-Footy, K.O.; Alarif, W.M.; Asiri, F.; Aly, M.M.; Ayyad, S.E. Rare pyrane-based cembranoids from the Red sea soft coral Sarcophyton trocheliophorum as potential antimicrobial-antitumor agents. Med. Chem. Res. 2015, 24, 505-512. [CrossRef]

66. Niu, S.; Liu, D.; Hu, X.; Proksch, P.; Shao, Z.; Lin, W. Spiromastixones A-O, antibacterial chlorodepsidones from a deep-sea-derived Spiromastix sp. fungus. J. Nat. Prod. 2014, 77, 1021-1030. [CrossRef]

67. Wu, B.; Oesker, V.; Wiese, J.; Malien, S.; Schmaljohann, R.; Imhoff, J.F. Spirocyclic drimanes from the marine fungus Stachybotrys sp. strain MF347. Mar. Drugs 2014, 12, 1924-1938. [CrossRef]

68. Reimer, A.; Blohm, A.; Quack, T.; Grevelding, C.G.; Kozjak-Pavlovic, V.; Rudel, T.; Hentschel, U.; Abdelmohsen, U.R. Inhibitory activities of the marine streptomycete-derived compound SF2446A2 against Chlamydia trachomatis and Schistosoma mansoni. J. Antibiot. 2015, 68, 674-679. [CrossRef]

69. Sun, X.P.; Cao, F.; Shao, C.L.; Wang, M.; Zhang, X.L.; Wang, C.Y. Antibacterial delta(1) -3-ketosteroids from the South China sea gorgonian coral Subergorgia rubra. Chem. Biodivers. 2015, 12, 1068-1074. [CrossRef]

70. Liaw, C.C.; Chen, P.C.; Shih, C.J.; Tseng, S.P.; Lai, Y.M.; Hsu, C.H.; Dorrestein, P.C.; Yang, Y.L. Vitroprocines, new antibiotics against Acinetobacter baumannii, discovered from marine Vibrio sp. QWI-06 using mass-spectrometry-based metabolomics approach. Sci. Rep. 2015, 5, 12856. [CrossRef]

71. Ayyad, S.E.; Katoua, D.F.; Alarif, W.M.; Sobahi, T.R.; Aly, M.M.; Shaala, L.A.; Ghandourah, M.A. Two new polyacetylene derivatives from the Red sea sponge Xestospongia sp. Z. Naturforsch. C 2015, 70, 297-303. [CrossRef]

72. Lee, S.H.; Moon, K.; Kim, H.; Shin, J.; Oh, D.C.; Oh, K.B. Bahamaolide A from the marine-derived Streptomyces sp. CNQ343 inhibits isocitrate lyase in Candida albicans. Bioorg. Med. Chem. Lett. 2014, 24, 4291-4293. [CrossRef]

73. Sugiyama, R.; Nishimura, S.; Matsumori, N.; Tsunematsu, Y.; Hattori, A.; Kakeya, H. Structure and biological activity of 8-deoxyheronamide $\mathrm{C}$ from a marine-derived Streptomyces sp.: Heronamides target saturated hydrocarbon chains in lipid membranes. J. Am. Chem. Soc. 2014, 136, 5209-5212. [CrossRef]

74. Wyche, T.P.; Piotrowski, J.S.; Hou, Y.; Braun, D.; Deshpande, R.; McIlwain, S.; Ong, I.M.; Myers, C.L.; Guzei, I.A.; Westler, W.M.; et al. Forazoline A: Marine-derived polyketide with antifungal in vivo efficacy. Angew. Chem. Int. Ed. Engl. 2014, 53, 11583-11586. [CrossRef]

75. Yu, H.B.; Yang, F.; Sun, F.; Li, J.; Jiao, W.H.; Gan, J.H.; Hu, W.Z.; Lin, H.W. Aaptamine derivatives with antifungal and anti-HIV-1 activities from the South China sea sponge Aaptos aaptos. Mar. Drugs 2014, 12, 6003-6013. [CrossRef]

76. Kubota, T.; Iwai, T.; Ishiyama, H.; Sakai, K.; Gonoi, T.; Kobayashi, J. Amphidinin G, a putative biosynthetic precursor of amphidinin A from marine dinoflagellate Amphidinium sp. Tetrahedron Lett. 2015, 56, 990-993. [CrossRef] 
77. Nuzzo, G.; Cutignano, A.; Sardo, A.; Fontana, A. Antifungal amphidinol 18 and its 7-sulfate derivative from the marine dinoflagellate Amphidinium carterae. J. Nat. Prod. 2014, 77, 1524-1527. [CrossRef]

78. Jamison, M.T.; Molinski, T.F. Antipodal crambescin A2 homologues from the marine sponge Pseudaxinella reticulata. Antifungal structure-activity relationships. J. Nat. Prod. 2015, 78, 557-561. [CrossRef]

79. Elbandy, M.; Rho, J.R.; Afifi, R. Analysis of saponins as bioactive zoochemicals from the marine functional food sea cucumber Bohadschia cousteaui. Eur. Food Res. Technol. 2014, 238, 937-955. [CrossRef]

80. Yu, X.Q.; He, W.F.; Liu, D.Q.; Feng, M.T.; Fang, Y.; Wang, B.; Feng, L.H.; Guo, Y.W.; Mao, S.C. A seco-laurane sesquiterpene and related laurane derivatives from the red alga Laurencia okamurai Yamada. Phytochemistry 2014, 103, 162-170. [CrossRef]

81. Feng, M.T.; Yu, X.Q.; Yang, P.; Yang, H.; Lin, K.; Mao, S.C. Two new antifungal polyunsaturated fatty acid ethyl esters from the red alga Laurencia okamurai. Chem. Nat. Compd. 2015, 51, 418-422. [CrossRef]

82. Bae, M.; Kim, H.; Moon, K.; Nam, S.J.; Shin, J.; Oh, K.B.; Oh, D.C. Mohangamides A and B, new dilactone-tethered pseudo-dimeric peptides inhibiting Candida albicans isocitrate lyase. Org. Lett. 2015, 17, 712-715. [CrossRef] [PubMed]

83. Chen, C.J.; Zhou, Y.; Liu, X.; Zhang, W.J.; Hu, S.; Lin, L.P.; HUO, G.M.; Jiao, R.H.; Tan, R.X.; Ge, H.M. Antimicrobial and anti-inflammatory compounds from a marine fungus Pleosporales sp. Tetrahedron Lett. 2015, 56, 6183-6189. [CrossRef]

84. Lin, K.; Yang, P.; Yang, H.; Liu, A.H.; Yao, L.G.; Guo, Y.W.; Mao, S.C. Lysophospholipids from the Guangxi sponge Spirastrella purpurea. Lipids 2015, 50, 697-703. [CrossRef] [PubMed]

85. Kubota, T.; Suzuki, H.; Takahashi-Nakaguchi, A.; Fromont, J.; Gonoi, T.; Kobayashi, J. Taurospongins B and $\mathrm{C}$, new acetylenic fatty acid derivatives possessing a taurine amide residu from a marine sponge of the family Spongiidae. RSC Adv. 2014, 4, 11073-11079. [CrossRef]

86. Wang, X.H.; Zou, Z.R.; Yi, Y.H.; Han, H.; Li, L.; Pan, M.X. Variegatusides: New non-sulphated triterpene glycosides from the sea cucumber Stichopus variegates semper. Mar. Drugs 2014, 12, 2004-2018. [CrossRef] [PubMed]

87. Young, R.M.; Adendorff, M.R.; Wright, A.D.; Davies-Coleman, M.T. Antiplasmodial activity: The first proof of inhibition of heme crystallization by marine isonitriles. Eur. J. Med. Chem. 2015, 93, 373-380. [CrossRef] [PubMed]

88. Cheng, K.C.; Cao, S.; Raveh, A.; MacArthur, R.; Dranchak, P.; Chlipala, G.; Okoneski, M.T.; Guha, R.; Eastman, R.T.; Yuan, J.; et al. Actinoramide A identified as a potent antimalarial from titration-based screening of marine natural product extracts. J. Nat. Prod. 2015, 78, 2411-2422. [CrossRef]

89. Yang, F.; Zou, Y.; Wang, R.P.; Hamann, M.T.; Zhang, H.J.; Jiao, W.H.; Han, B.N.; Song, S.J.; Lin, H.W. Relative and absolute stereochemistry of diacarperoxides: Antimalarial norditerpene endoperoxides from marine sponge Diacarnus megaspinorhabdosa. Mar. Drugs 2014, 12, 4399-4416. [CrossRef]

90. Thao, N.P.; Luyen, B.T.; Brun, R.; Kaiser, M.; Van, K.P.; Van, M.C.; Schmidt, T.J.; Kang, J.S.; Kim, Y.H. Anti-protozoal activities of cembrane-type diterpenes from Vietnamese soft corals. Molecules 2015, 20, 12459-12468. [CrossRef]

91. Aviles, E.; Prudhomme, J.; Le Roch, K.G.; Rodriguez, A.D. Structures, semisyntheses, and absolute configurations of the antiplasmodial alpha-substituted beta-lactam monamphilectines $\mathrm{B}$ and $\mathrm{C}$ from the sponge Svenzea flava. Tetrahedron 2015, 71, 487-494. [CrossRef]

92. Gros, E.; Al-Mourabit, A.; Martin, M.T.; Sorres, J.; Vacelet, J.; Frederich, M.; Aknin, M.; Kashman, Y.; Gauvin-Bialecki, A. Netamines H-N, tricyclic alkaloids from the marine sponge Biemna laboutei and their antimalarial activity. J. Nat. Prod. 2014, 77, 818-823. [CrossRef] [PubMed]

93. White, A.M.; Pierens, G.K.; Skinner-Adams, T.; Andrews, K.T.; Bernhardt, P.V.; Krenske, E.H.; Mollo, E.; Garson, M.J. Antimalarial isocyano and isothiocyanato sesquiterpenes with tri- and bicyclic skeletons from the nudibranch Phyllidia ocellata. J. Nat. Prod. 2015, 78, 1422-1427. [CrossRef] [PubMed]

94. Chianese, G.; Persico, M.; Yang, F.; Lin, H.W.; Guo, Y.W.; Basilico, N.; Parapini, S.; Taramelli, D.; Taglialatela-Scafati, O.; Fattorusso, C. Endoperoxide polyketides from a Chinese Plakortis simplex: Further evidence of the impact of stereochemistry on antimalarial activity of simple 1,2-dioxanes. Bioorg. Med. Chem. 2014, 22, 4572-4580. [CrossRef] [PubMed]

95. Oli, S.; Abdelmohsen, U.R.; Hentschel, U.; Schirmeister, T. Identification of plakortide E from the Caribbean sponge Plakortis halichondroides as a trypanocidal protease inhibitor using bioactivity-guided fractionation. Mar. Drugs 2014, 12, 2614-2622. [CrossRef] [PubMed] 
96. Santos, M.F.; Harper, P.M.; Williams, D.E.; Mesquita, J.T.; Pinto, E.G.; da Costa-Silva, T.A.; Hajdu, E.; Ferreira, A.G.; Santos, R.A.; Murphy, P.J.; et al. Anti-parasitic guanidine and pyrimidine alkaloids from the marine sponge Monanchora arbuscula. J. Nat. Prod. 2015, 78, 1101-1112. [CrossRef] [PubMed]

97. Abdelmohsen, U.R.; Cheng, C.; Viegelmann, C.; Zhang, T.; Grkovic, T.; Ahmed, S.; Quinn, R.J.; Hentschel, U.; Edrada-Ebel, R. Dereplication strategies for targeted isolation of new antitrypanosomal actinosporins A and B from a marine sponge associated-Actinokineospora sp. EG49. Mar. Drugs 2014, 12, 1220-1244. [CrossRef]

98. Thao, N.P.; No, J.H.; Luyen, B.T.; Yang, G.; Byun, S.Y.; Goo, J.; Kim, K.T.; Cuong, N.X.; Nam, N.H.; Van, M.C.; et al. Secondary metabolites from Vietnamese marine invertebrates with activity against Trypanosoma brucei and T. cruzi. Molecules 2014, 19, 7869-7880. [CrossRef]

99. Viegelmann, C.; Parker, J.; Ooi, T.; Clements, C.; Abbott, G.; Young, L.; Kennedy, J.; Dobson, A.D.; Edrada-Ebel, R. Isolation and identification of antitrypanosomal and antimycobacterial active steroids from the sponge Haliclona simulans. Mar. Drugs 2014, 12, 2937-2952. [CrossRef]

100. Schulze, C.J.; Donia, M.S.; Siqueira-Neto, J.L.; Ray, D.; Raskatov, J.A.; Green, R.E.; McKerrow, J.H.; Fischbach, M.A.; Linington, R.G. Genome-directed lead discovery: Biosynthesis, structure elucidation, and biological evaluation of two families of polyene macrolactams against Trypanosoma brucei. ACS Chem. Biol. 2015, 10, 2373-2381. [CrossRef]

101. Nakashima, T.; Iwatsuki, M.; Ochiai, J.; Kamiya, Y.; Nagai, K.; Matsumoto, A.; Ishiyama, A.; Otoguro, K.; Shiomi, K.; Takahashi, Y.; et al. Mangromicins A and B: Structure and antitrypanosomal activity of two new cyclopentadecane compounds from Lechevalieria aerocolonigenes K10-0216. J. Antibiot. 2014, 67, 253-260. [CrossRef]

102. Yang, F.; Gan, J.H.; Liu, X.Y.; Lin, H.W. Scalarane sesterterpenes from the Paracel islands marine sponge Hyrtios sp. Nat. Prod. Commun. 2014, 9, 763-764. [CrossRef] [PubMed]

103. von Salm, J.L.; Wilson, N.G.; Vesely, B.A.; Kyle, D.E.; Cuce, J.; Baker, B.J. Shagenes A and B, new tricyclic sesquiterpenes produced by an undescribed Antarctic octocoral. Org. Lett. 2014, 16, 2630-2633. [CrossRef] [PubMed]

104. Arai, M.; Han, C.; Yamano, Y.; Setiawan, A.; Kobayashi, M. Aaptamines, marine spongean alkaloids, as anti-dormant mycobacterial substances. J. Nat. Med. 2014, 68, 372-376. [CrossRef] [PubMed]

105. Daletos, G.; Kalscheuer, R.; Koliwer-Brandl, H.; Hartmann, R.; de Voogd, N.J.; Wray, V.; Lin, W.; Proksch, P. Callyaerins from the marine sponge Callyspongia aerizusa: Cyclic peptides with antitubercular activity. J. Nat. Prod. 2015, 78, 1910-1925. [CrossRef]

106. Kumar, M.M.K.; Naik, J.D.; Satyavathi, K.; Ramana, H.; Varma, P.R.; Nagasree, K.P. Denigrins A-C: New antitubercular 3,4-diarylpyrrole alkaloids from Dendrilla nigra. Nat. Prod. Res. 2014, 28, 888-894. [CrossRef]

107. Lin, Z.; Koch, M.; Abdel Aziz, M.H.; Galindo-Murillo, R.; Tianero, M.D.; Cheatham, T.E.; Barrows, L.R.; Reilly, C.A.; Schmidt, E.W. Oxazinin A, a pseudodimeric natural product of mixed biosynthetic origin from a filamentous fungus. Org. Lett. 2014, 16, 4774-4777. [CrossRef]

108. Gonzalez-Almela, E.; Sanz, M.A.; Garcia-Moreno, M.; Northcote, P.; Pelletier, J.; Carrasco, L. Differential action of pateamine A on translation of genomic and subgenomic mRNAs from Sindbis virus. Virology 2015, 484, 41-50. [CrossRef]

109. Leon, B.; Navarro, G.; Dickey, B.J.; Stepan, G.; Tsai, A.; Jones, G.S.; Morales, M.E.; Barnes, T.; Ahmadyar, S.; Tsiang, M.; et al. Abyssomicin 2 reactivates latent HIV-1 by a PKC- and HDAC-independent mechanism. Org. Lett. 2015, 17, 262-265. [CrossRef]

110. Karadeniz, F.; Kang, K.H.; Park, J.W.; Park, S.J.; Kim, S.K. Anti-HIV-1 activity of phlorotannin derivative 8,4"'-dieckol from Korean brown alga Ecklonia cava. Biosci. Biotechnol. Biochem. 2014, 78, 1151-1158. [CrossRef]

111. Zhao, Y.; Si, L.; Liu, D.; Proksch, P.; Zhou, D.; Lin, W. Truncateols A-N, new isoprenylated cyclohexanols from the sponge-associated fungus Truncatella angustata with anti-H1N1 virus activities. Tetrahedron 2015, 71, 2708-2718. [CrossRef]

112. Chen, X.; Si, L.; Liu, D.; Proksch, P.; Zhang, L.; Zhou, D.; Lin, W. Neoechinulin B and its analogues as potential entry inhibitors of influenza viruses, targeting viral hemagglutinin. Eur. J. Med. Chem. 2015, 93, 182-195. [CrossRef] [PubMed]

113. Li, W.; Jiang, Z.; Shen, L.; Pedpradab, P.; Bruhn, T.; Wu, J.; Bringmann, G. Antiviral limonoids including Khayanolides from the Trang mangrove plant Xylocarpus moluccensis LI2015. J. Nat. Prod. 2015, 78, 1570-1578. [CrossRef] [PubMed] 
114. Chen, M.; Shao, C.L.; Meng, H.; She, Z.G.; Wang, C.Y. Anti-respiratory syncytial virus prenylated dihydroquinolone derivatives from the gorgonian-derived fungus Aspergillus sp. XS-20090B15. J. Nat. Prod. 2014, 77, 2720-2724. [CrossRef] [PubMed]

115. Nong, X.H.; Wang, Y.F.; Zhang, X.Y.; Zhou, M.P.; Xu, X.Y.; Qi, S.H. Territrem and butyrolactone derivatives from a marine-derived fungus Aspergillus terreus. Mar. Drugs 2014, 12, 6113-6124. [CrossRef] [PubMed]

116. Li, Y.; Liu, D.; Cen, S.; Proksch, P.; Lin, W. Isoindolinone-type alkaloids from the sponge-derived fungus Stachybotrys chartarum. Tetrahedron 2014, 70, 7010-7015. [CrossRef]

117. Gupta, D.K.; Kaur, P.; Leong, S.T.; Tan, L.T.; Prinsep, M.R.; Chu, J.J. Anti-Chikungunya viral activities of aplysiatoxin-related compounds from the marine cyanobacterium Trichodesmium erythraeum. Mar. Drugs 2014, 12, 115-127. [CrossRef]

118. Pardo-Vargas, A.; de Barcelos Oliveira, I.; Stephens, P.R.; Cirne-Santos, C.C.; de Palmer Paixao, I.C.; Ramos, F.A.; Jimenez, C.; Rodriguez, J.; Resende, J.A.; Teixeira, V.L.; et al. Dolabelladienols A-C, new diterpenes isolated from Brazilian brown alga Dictyota pfaffii. Mar. Drugs 2014, 12, 4247-4259. [CrossRef]

119. Cheng, S.; Zhao, M.; Sun, Z.; Yuan, W.; Zhang, S.; Xiang, Z.; Cai, Y.; Dong, J.; Huang, K.; Yan, P. Diterpenes from a Chinese collection of the brown alga Dictyota plectens. J. Nat. Prod. 2014, 77, 2685-2693. [CrossRef]

120. Yamashita, A.; Fujimoto, Y.; Tamaki, M.; Setiawan, A.; Tanaka, T.; Okuyama-Dobashi, K.; Kasai, H.; Watashi, K.; Wakita, T.; Toyama, M.; et al. Identification of antiviral agents targeting Hepatitis B virus promoter from extracts of Indonesian marine organisms by a novel cell-based screening assay. Mar. Drugs 2015, 13, 6759-6773. [CrossRef]

121. Cao, F.; Shao, C.L.; Chen, M.; Zhang, M.Q.; Xu, K.X.; Meng, H.; Wang, C.Y. Antiviral C-25 epimers of 26-acetoxy steroids from the South China sea gorgonian Echinogorgia rebekka. J. Nat. Prod. 2014, 77, 1488-1493. [CrossRef]

122. Jia, Y.L.; Wei, M.Y.; Chen, H.Y.; Guan, F.F.; Wang, C.Y.; Shao, C.L. (+)- and (-)-Pestaloxazine A, a pair of antiviral enantiomeric alkaloid dimers with a symmetric spiro[oxazinane-piperazinedione] skeleton from Pestalotiopsis sp. Org. Lett. 2015, 17, 4216-4219. [CrossRef] [PubMed]

123. Eom, S.H.; Moon, S.Y.; Lee, D.S.; Kim, H.J.; Park, K.; Lee, E.W.; Kim, T.H.; Chung, Y.H.; Lee, M.S.; Kim, Y.M. In vitro antiviral activity of dieckol and phlorofucofuroeckol-A isolated from edible brown alga Eisenia bicyclis against murine norovirus. Algae 2015, 30, 241-246. [CrossRef]

124. Cheng, S.Y.; Wang, S.K.; Duh, C.Y. Secocrassumol, a seco-cembranoid from the Dongsha atoll soft coral Lobophytum crassum. Mar. Drugs 2014, 12, 6028-6037. [CrossRef] [PubMed]

125. Dineshkumar, K.; Aparna, V.; Madhuri, K.Z.; Hopper, W. Biological activity of sporolides A and B from Salinispora tropica: In silico target prediction using ligand-based pharmacophore mapping and in vitro activity validation on HIV-1 reverse transcriptase. Chem. Biol. Drug Des. 2014, 83, 350-361. [CrossRef] [PubMed]

126. Shin, H.J.; Rashid, M.A.; Cartner, L.K.; Bokesch, H.R.; Wilson, J.A.; McMahon, J.B.; Gustafson, K.R. Stellettapeptins A and B, HIV-inhibitory cyclic depsipeptides from the marine sponge Stelleta sp. Tetrahedron Lett. 2015, 56, 4215-4219. [CrossRef] [PubMed]

127. Sun, Y.L.; Wang, J.; Wang, Y.F.; Zhang, X.Y.; Nong, X.H.; Chen, M.; Xu, X.Y. Cytotoxic and antiviral tetramic acid derivatives from the deep-sea-derived fungus Trichobotrys effuse DFFSCS021. Tetrahedron 2015, 71, 9328-9332. [CrossRef]

128. Farrugia, M.; Trotter, N.; Vijayasarathy, S.; Salim, A.A.; Khalil, Z.G.; Lacey, E.; Capon, R.J. Isolation and synthesis of $\mathrm{N}$-acyladenine and adenosine alkaloids from a southern Australian marine sponge, Phoriospongia sp. Tetrahedron Lett. 2014, 55, 5902-5904. [CrossRef]

129. Woo, J.K.; Kim, C.K.; Kim, S.H.; Kim, H.; Oh, D.C.; Oh, K.B.; Shin, J. Gombaspiroketals A-C, sesterterpenes from the sponge Clathria gombawuiensis. Org. Lett. 2014, 16, 2826-2829. [CrossRef]

130. Cantisani, M.; Finamore, E.; Mignogna, E.; Falanga, A.; Nicoletti, G.F.; Pedone, C.; Morelli, G.; Leone, M.; Galdiero, M.; Galdiero, S. Structural insights into and activity analysis of the antimicrobial peptide myxinidin. Antimicrob. Agents Chemother. 2014, 58, 5280-5290. [CrossRef]

131. Kusama, T.; Tanaka, N.; Sakai, K.; Gonoi, T.; Fromont, J.; Kashiwada, Y.; Kobayashi, J. Agelamadins C-E, bromopyrrole alkaloids comprising oroidin and 3-hydroxykynurenine from a marine sponge Agelas sp. Org. Lett. 2014, 16, 5176-5179. [CrossRef]

132. Sun, K.; Li, Y.; Guo, L.; Wang, Y.; Liu, P.; Zhu, W. Indole diterpenoids and isocoumarin from the fungus, Aspergillus flavus, isolated from the prawn, Penaeus vannamei. Mar. Drugs 2014, 12, 3970-3981. [CrossRef] [PubMed] 
133. Nakamura, K.; Kusama, T.; Tanaka, N.; Gonoi, T.; Fromont, J.; Kobayashi, J. 2-Debromonagelamide U, 2-Debromomukanadin G, and 2-Debromonagelamide P from marine sponge Agelas sp. Heterocycles 2015, 90, 425-431.

134. Huang, Q.; Cheng, W.; Long, H.; Liu, H.; van Ofwegen, L.; Lin, W. Subergane-type sesquiterpenes from Gorgonian coral Subergorgia suberosa with antibacterial activities. Helv. Chim. Acta 2015, 98, 1202-1209. [CrossRef]

135. Gotsbacher, M.P.; Karuso, P. New antimicrobial bromotyrosine analogues from the sponge Pseudoceratina purpurea and its predator Tylodina corticalis. Mar. Drugs 2015, 13, 1389-1409. [CrossRef]

136. Hawas, U.W.; El-Desouky, S.; El-Kassem, A.; Elkhateeb, W. Alternariol derivatives from Alternaria alternata, an endophytic fungus residing in red sea soft coral, inhibit HCV NS3/4A protease. Appl. Biochem. Microbiol. 2015, 51, 579-584. [CrossRef]

137. Kubota, T.; Iwai, T.; Sakai, K.; Gonoi, T.; Kobayashi, J. Amphidinins C-F, amphidinolide Q analogues from marine dinoflagellate Amphidinium sp. Org. Lett. 2014, 16, 5624-5627. [CrossRef]

138. Dasyam, N.; Munkacsi, A.B.; Fadzilah, N.H.; Senanayake, D.S.; O'Toole, R.F.; Keyzers, R.A. Identification and bioactivity of 3-epi-xestoaminol $\mathrm{C}$ isolated from the New Zealand brown alga Xiphophora chondrophylla. J. Nat. Prod. 2014, 77, 1519-1523. [CrossRef]

139. Chen, M.; Shao, C.L.; Fu, X.M.; Kong, C.J.; She, Z.G.; Wang, C.Y. Lumazine peptides penilumamides B-D and the cyclic pentapeptide asperpeptide A from a gorgonian-derived Aspergillus sp. fungus. J. Nat. Prod. 2014, 77, 1601-1606. [CrossRef]

140. Chen, M.; Fu, X.M.; Kong, C.J.; Wang, C.Y. Nucleoside derivatives from the marine-derived fungus Aspergillus versicolor. Nat. Prod. Res. 2014, 28, 895-900. [CrossRef]

141. Du, F.Y.; Li, X.M.; Zhang, P.; Li, C.S.; Wang, B.G. Cyclodepsipeptides and other O-containing heterocyclic metabolites from Beauveria felina EN-135, a marine-derived entomopathogenic fungus. Mar. Drugs 2014, 12, 2816-2826. [CrossRef]

142. Eltamany, E.E.; Abdelmohsen, U.R.; Ibrahim, A.K.; Hassanean, H.A.; Hentschel, U.; Ahmed, S.A. New antibacterial xanthone from the marine sponge-derived Micrococcus sp. EG45. Bioorg. Med. Chem. Lett. 2014, 24, 4939-4942. [CrossRef] [PubMed]

143. Song, Y.; Li, Q.; Liu, X.; Chen, Y.; Zhang, Y.; Sun, A.; Zhang, W.; Zhang, J.; Ju, J. Cyclic Hexapeptides from the deep South China sea-derived Streptomyces scopuliridis SCSIO ZJ46 active against pathogenic Gram-positive bacteria. J. Nat. Prod. 2014, 77, 1937-1941. [CrossRef] [PubMed]

144. Tareq, F.S.; Hasan, C.M.; Lee, H.S.; Lee, Y.J.; Lee, J.S.; Surovy, M.Z.; Islam, M.T.; Shin, H.J. Gageopeptins A and $\mathrm{B}$, new inhibitors of zoospore motility of the phytopathogen Phytophthora capsici from a marine-derived bacterium Bacillus sp. 109GGC020. Bioorg. Med. Chem. Lett. 2015, 25, 3325-3329. [CrossRef] [PubMed]

145. Kunz, A.L.; Labes, A.; Wiese, J.; Bruhn, T.; Bringmann, G.; Imhoff, J.F. Nature's lab for derivatization: New and revised structures of a variety of streptophenazines produced by a sponge-derived Streptomyces strain. Mar. Drugs 2014, 12, 1699-1714. [CrossRef] [PubMed]

146. Salvador-Reyes, L.A.; Sneed, J.; Paul, V.J.; Luesch, H. Amantelides A and B, Polyhydroxylated macrolides with differential broad-spectrum cytotoxicity from a Guamanian marine cyanobacterium. J. Nat. Prod. 2015, 78, 1957-1962. [CrossRef] [PubMed]

147. Zhen, X.; Gong, T.; Liu, F.; Zhang, P.C.; Zhou, W.Q.; Li, Y.; Zhu, P. A new analogue of echinomycin and a new cyclic dipeptide from a marine-derived Streptomyces sp. LS298. Mar. Drugs 2015, 13, 6947-6961. [CrossRef]

148. Youssef, D.T.A.; Badr, J.M.; Shaala, L.A.; Mohamed, G.A.; Baer, R.J.; Bamanie, F.H. Ehrenasterol and biemnic acid; new bioactive compounds from the Red sea sponge Biemna ehrenbergi. Phytochem. Lett. 2015, 12, $296-301$. [CrossRef]

149. Smyrniotopoulos, V.; Rae, M.; Soldatou, S.; Ding, Y.; Wolff, C.W.; McCormack, G.; Coleman, C.M.; Ferreira, D.; Tasdemir, D. Sulfated steroid-amino acid conjugates from the Irish marine sponge Polymastia boletiformis. Mar. Drugs 2015, 13, 1632-1646. [CrossRef]

150. Kubota, T.; Watase, S.; Sakai, K.; Fromont, J.; Gonoi, T.; Kobayashi, J. Tyrokeradines G and H, new bromotyrosine alkaloids from an Okinawan Verongid sponge. Bioorg. Med. Chem. Lett. 2015, 25, 5221-5223. [CrossRef]

151. Xu, X.; Yin, L.; Gao, J.; Gao, L.; Song, F. Antifungal bromophenols from marine red alga Symphyocladia latiuscula. Chem. Biodivers. 2014, 11, 807-811. [CrossRef] 
152. Koch, L.; Lodin, A.; Herold, I.; Ilan, M.; Carmeli, S.; Yarden, O. Sensitivity of Neurospora crassa to a marine-derived Aspergillus tubingensis anhydride exhibiting antifungal activity that is mediated by the MAS1 protein. Mar. Drugs 2014, 12, 4713-4731. [CrossRef] [PubMed]

153. Shaala, L.A.; Youssef, D.T. Identification and bioactivity of compounds from the fungus Penicillium sp. CYE-87 isolated from a marine tunicate. Mar. Drugs 2015, 13, 1698-1709. [CrossRef] [PubMed]

154. Maeda, H.; Kanno, S.; Kodate, M.; Hosokawa, M.; Miyashita, K. Fucoxanthinol, metabolite of fucoxanthin, improves obesity-induced inflammation in adipocyte cells. Mar. Drugs 2015, 13, 4799-4813. [CrossRef] [PubMed]

155. Kang, M.C.; Lee, S.H.; Lee, W.W.; Kang, N.; Kim, E.A.; Kim, S.Y.; Lee, D.H.; Kim, D.; Jeon, Y.J. Protective effect of fucoxanthin isolated from Ishige okamurae against high-glucose induced oxidative stress in human umbilical vein endothelial cells and zebrafish model. J. Funct. Foods 2014, 11, 304-312. [CrossRef]

156. Lee, S.H.; Kang, S.M.; Ko, S.C.; Moon, S.H.; Jeon, B.T.; Lee, D.H.; Jeon, Y.J. Octaphlorethol A: A potent alpha-glucosidase inhibitor isolated from Ishige foliacea shows an anti-hyperglycemic effect in mice with streptozotocin-induced diabetes. Food Funct. 2014, 5, 2602-2608. [CrossRef]

157. You, H.N.; Lee, H.A.; Park, M.H.; Lee, J.H.; Han, J.S. Phlorofucofuroeckol A isolated from Ecklonia cava alleviates postprandial hyperglycemia in diabetic mice. Eur. J. Pharmacol. 2015, 752, 92-96. [CrossRef]

158. Safavi-Hemami, H.; Gajewiak, J.; Karanth, S.; Robinson, S.D.; Ueberheide, B.; Douglass, A.D.; Schlegel, A.; Imperial, J.S.; Watkins, M.; Bandyopadhyay, P.K.; et al. Specialized insulin is used for chemical warfare by fish-hunting cone snails. Proc. Natl. Acad. Sci. USA 2015, 112, 1743-1748. [CrossRef]

159. Yamazaki, H.; Takahashi, O.; Kanno, S.; Nakazawa, T.; Takahashi, S.; Ukai, K.; Sumilat, D.A.; Ishikawa, M.; Namikoshi, M. Absolute structures and bioactivities of euryspongins and eurydiene obtained from the marine sponge Euryspongia sp. collected at Iriomote island. Bioorg. Med. Chem. 2015, 23, 797-802. [CrossRef]

160. Xia, X.; Qi, J.; Liu, Y.; Jia, A.; Zhang, Y.; Liu, C.; Gao, C.; She, Z. Bioactive isopimarane diterpenes from the fungus, Epicoccum sp. HS-1, associated with Apostichopus japonicus. Mar. Drugs 2015, 13, 1124-1132. [CrossRef]

161. Shin, B.; Ahn, S.; Noh, M.; Shin, J.; Oh, D.C. Suncheonosides A-D, benzothioate glycosides from a marine-derived Streptomyces sp. J. Nat. Prod. 2015, 78, 1390-1396. [CrossRef]

162. You, M.; Liao, L.; Hong, S.H.; Park, W.; Kwon, D.I.; Lee, J.; Noh, M.; Oh, D.C.; Oh, K.B.; Shin, J. Lumazine peptides from the marine-derived fungus Aspergillus terreus. Mar. Drugs 2015, 13, 1290-1303. [CrossRef] [PubMed]

163. He, W.F.; Liang, L.F.; Cai, Y.S.; Gao, L.X.; Li, Y.F.; Li, J.; Liu, H.L.; Guo, Y.W. Brominated polyunsaturated lipids with protein tyrosine phosphatase-1B inhibitory activity from Chinese marine sponge Xestospongia testudinaria. J. Asian Nat. Prod. Res. 2015, 17, 861-866. [CrossRef] [PubMed]

164. Taira, J.; Tsuchida, E.; Uehara, M.; Kinjyo, Y.; Roy, P.K.; Ueda, K. Dual biological functions of the apoptotic activity and anti-inflammatory effect by alcyonolide congeners from the Okinawan soft coral, Cespitularia sp. Bioorg. Med. Chem. Lett. 2015, 25, 4496-4499. [CrossRef] [PubMed]

165. Guo, S.X.; Zhou, H.L.; Huang, C.L.; You, C.G.; Fang, Q.; Wu, P.; Wang, X.G.; Han, C.M. Astaxanthin attenuates early acute kidney injury following severe burns in rats by ameliorating oxidative stress and mitochondrial-related apoptosis. Mar. Drugs 2015, 13, 2105-2123. [CrossRef] [PubMed]

166. Yang, Y.I.; Jung, S.H.; Lee, K.T.; Choi, J.H. 8,8'-Bieckol, isolated from edible brown algae, exerts its anti-inflammatory effects through inhibition of NF-kappaB signaling and ROS production in LPS-stimulated macrophages. Int. Immunopharmacol. 2014, 23, 460-468. [CrossRef]

167. Fernandes, P.D.; Zardo, R.S.; Figueiredo, G.S.; Silva, B.V.; Pinto, A.C. Anti-inflammatory properties of convolutamydine A and two structural analogues. Life Sci. 2014, 116, 16-24. [CrossRef]

168. Phan, C.S.; Ng, S.Y.; Kim, E.A.; Jeon, Y.J.; Palaniveloo, K.; Vairappan, C.S. Capgermacrenes A and B, bioactive secondary metabolites from a Bornean soft coral, Capnella sp. Mar. Drugs 2015, 13, 3103-3115. [CrossRef]

169. Jimenez-Romero, C.; Mayer, A.M.; Rodriguez, A.D. Dactyloditerpenol acetate, a new prenylbisabolane-type diterpene from Aplysia dactylomela with significant in vitro anti-neuroinflammatory activity. Bioorg. Med. Chem. Lett. 2014, 24, 344-348. [CrossRef]

170. Choi, H.J.; Park, J.H.; Lee, B.H.; Chee, H.Y.; Lee, K.B.; Oh, S.M. Suppression of NF-kappaB by dieckol extracted from Ecklonia cava negatively regulates LPS induction of inducible nitric oxide synthase gene. Appl. Biochem. Biotechnol. 2014, 173, 957-967. [CrossRef] 
171. Kang, N.J.; Koo, D.H.; Kang, G.J.; Han, S.C.; Lee, B.W.; Koh, Y.S.; Hyun, J.W.; Lee, N.H.; Ko, M.H.; Kang, H.K.; et al. Dieckol, a component of Ecklonia cava, suppresses the production of MDC/CCL22 via down-regulating STAT1 pathway in interferon-gamma stimulated HaCaT human keratinocytes. Biomol. Ther. 2015, 23, 238-244. [CrossRef]

172. Lin, Y.Y.; Lin, S.C.; Feng, C.W.; Chen, P.C.; Su, Y.D.; Li, C.M.; Yang, S.N.; Jean, Y.H.; Sung, P.J.; Duh, C.Y.; et al. Anti-inflammatory and analgesic effects of the marine-derived compound excavatolide $B$ isolated from the culture-type Formosan gorgonian Briareum excavatum. Mar. Drugs 2015, 13, 2559-2579. [CrossRef] [PubMed]

173. Chen, N.F.; Huang, S.Y.; Lu, C.H.; Chen, C.L.; Feng, C.W.; Chen, C.H.; Hung, H.C.; Lin, Y.Y.; Sung, P.J.; Sung, C.S.; et al. Flexibilide obtained from cultured soft coral has anti-neuroinflammatory and analgesic effects through the upregulation of spinal transforming growth factor-beta1 in neuropathic rats. Mar. Drugs 2014, 12, 3792-3817. [CrossRef] [PubMed]

174. Kim, M.J.; Lee, H.H.; Jeong, J.W.; Seo, M.J.; Kang, B.W.; Park, J.U.; Kim, K.S.; Cho, Y.S.; Seo, K.I.; Kim, G.Y.; et al. Anti-inflammatory effects of 5-hydroxy-3,6,7,8,3', $4^{\prime}$-hexamethoxyflavone via NF-kappaB inactivation in lipopolysaccharide-stimulated RAW 264.7 macrophage. Mol. Med. Rep. 2014, 9, 1197-1203. [CrossRef] [PubMed]

175. Wijesinghe, W.A.; Kang, M.C.; Lee, W.W.; Lee, H.S.; Kamada, T.; Vairappan, C.S.; Jeon, Y.J. 5ß-Hydroxypalisadin B isolated from red alga Laurencia snackeyi attenuates inflammatory response in lipopolysaccharide-stimulated RAW 264.7 macrophages. Algae 2014, 29, 333-341. [CrossRef]

176. Huang, C.Y.; Sung, P.J.; Uvarani, C.; Su, J.H.; Lu, M.C.; Hwang, T.L.; Dai, C.F.; Wu, S.L.; Sheu, J.H. Glaucumolides A and B, biscembranoids with new structural type from a cultured soft coral Sarcophyton glaucum. Sci. Rep. 2015, 5, 15624. [CrossRef]

177. Yu, D.K.; Lee, B.; Kwon, M.; Yoon, N.; Shin, T.; Kim, N.G.; Choi, J.S.; Kim, H.R. Phlorofucofuroeckol B suppresses inflammatory responses by down-regulating nuclear factor kappaB activation via Akt, ERK, and JNK in LPS-stimulated microglial cells YU2015. Int. Immunopharmacol. 2015, 28, 1068-1075. [CrossRef]

178. Banskota, A.H.; Stefanova, R.; Sperker, S.; Lall, S.P.; Craigie, J.S.; Hafting, J.T.; Critchley, A.T. Polar lipids from the marine macroalga Palmaria palmata inhibit lipopolysaccharide-induced nitric oxide production in RAW264.7 macrophage cells. Phytochemistry 2014, 101, 101-108. [CrossRef]

179. Itoh, T.; Koketsu, M.; Yokota, N.; Touho, S.; Ando, M.; Tsukamasa, Y. Reduced scytonemin isolated from Nostoc commune suppresses LPS/IFNgamma-induced NO production in murine macrophage RAW264 cells by inducing hemeoxygenase-1 expression via the Nrf2/ARE pathway. Food Chem. Toxicol. 2014, 69, 330-338. [CrossRef]

180. Lillsunde, K.E.; Festa, C.; Adel, H.; De, M.S.; Lombardi, V.; Tilvi, S.; Nawrot, D.A.; Zampella, A.; D’Souza, L.; D'Auria, M.V.; et al. Bioactive cembrane derivatives from the Indian ocean soft coral, Sinularia kavarattiensis. Mar. Drugs 2014, 12, 4045-4068. [CrossRef]

181. Thao, N.P.; Luyen, B.T.; Sun, Y.N.; Song, S.B.; Thanh, N.V.; Cuong, N.X.; Nam, N.H.; Kiem, P.V.; Kim, Y.H.; Minh, C.V. NF-kappaB inhibitory activity of polyoxygenated steroids from the Vietnamese soft coral Sarcophyton pauciplicatum. Bioorg. Med. Chem. Lett. 2014, 24, 2834-2838. [CrossRef]

182. Thao, N.P.; Nam, N.H.; Cuong, N.X.; Luyen, B.T.; Tai, B.H.; Kim, J.E.; Song, S.B.; Kiem, P.V.; Minh, C.V.; Kim, Y.H. Inhibition of NF-kappaB transcriptional activation in HepG2 cells by diterpenoids from the soft coral Sinularia maxima. Arch. Pharm. Res. 2014, 37, 706-712. [CrossRef] [PubMed]

183. Quang, T.H.; Ngan, N.T.T.; Ko, W.; Kim, D.C.; Yoon, C.S.; Sohn, J.H.; Yim, J.H.; Kim, Y.C.; Oh, H. Tanzawaic acid derivatives from a marine isolate of Penicillium sp. (SF-6013) with anti-inflammatory and PTP1B inhibitory activities. Bioorg. Med. Chem. Lett. 2014, 24, 5787-5791. [CrossRef] [PubMed]

184. Wang, Y.; Qi, S.; Zhan, Y.; Zhang, N.; Wu, A.A.; Gui, F.; Guo, K.; Yang, Y.; Cao, S.; Hu, Z.; et al. Aspertetranones A-D, putative meroterpenoids from the marine algal-associated fungus Aspergillus sp. ZL0-1b14. J. Nat. Prod. 2015, 78, 2405-2410. [CrossRef] [PubMed]

185. Su, Y.D.; Cheng, C.H.; Chen, W.F.; Chang, Y.C.; Chen, Y.H.; Hwang, T.L.; Wen, Z.H.; Wang, W.H.; Fang, L.S.; Chen, J.J.; et al. Briarenolide J, the first 12-chlorobriarane diterpenoid from an octoral Briareum sp. (Briareidae). Tetrahedron 2014, 55, 6065-6067. [CrossRef]

186. Su, Y.D.; Su, T.R.; Wen, Z.H.; Hwang, T.L.; Fang, L.S.; Chen, J.J.; Wu, Y.C.; Sheu, J.H.; Sung, P.J. Briarenolides K and $\mathrm{L}$, new anti-inflammatory briarane diterpenoids from an octocoral Briareum sp. (Briareidae). Mar. Drugs 2015, 13, 1037-1050. [CrossRef] [PubMed] 
187. Su, Y.D.; Wu, T.Y.; Wen, Z.H.; Su, C.C.; Chen, Y.H.; Chang, Y.C.; Wu, Y.C.; Sheu, J.H.; Sung, P.J. Briarenolides U-Y, New anti-inflammatory briarane diterpenoids from an octocoral Briareum sp. (Briareidae). Mar. Drugs 2015, 13, 7138-7149. [CrossRef] [PubMed]

188. Liaw, C.C.; Cheng, Y.B.; Lin, Y.S.; Kuo, Y.H.; Hwang, T.L.; Shen, Y.C. New briarane diterpenoids from Taiwanese soft coral Briareum violacea. Mar. Drugs 2014, 12, 4677-4692. [CrossRef]

189. Wagner, M.; Abdel-Mageed, W.M.; Ebel, R.; Bull, A.T.; Goodfellow, M.; Fiedler, H.P.; Jaspars, M. Dermacozines H-J isolated from a deep-sea strain of Dermacoccus abyssi from Mariana trench sediments. J. Nat. Prod. 2014, 77, 416-420. [CrossRef]

190. Jiao, W.H.; Xu, T.T.; Zhao, F.; Gao, H.; Shi, G.H.; Wang, J.; Hong, L.L.; Yu, H.B.; Li, Y.S.; Yang, F.; et al. Dysifragilones A-C, unusual sesquiterpene aminoquinones and inhibitors of NO production from the South China sea sponge Dysidea fragilis. Eur. J. Org. Chem. 2015, 2015, 960-966. [CrossRef]

191. Zhao, M.; Cheng, S.; Yuan, W.; Dong, J.; Huang, K.; Sun, Z.; Yan, P. Further new xenicanes from a Chinese collection of the brown alga Dictyota plectens. Chem. Pharm. Bull. 2015, 63, 1081-1086. [CrossRef]

192. Chen, L.C.; Lin, Y.Y.; Jean, Y.H.; Lu, Y.; Chen, W.F.; Yang, S.N.; Wang, H.M.; Jang, I.Y.; Chen, I.M.; Su, J.H.; et al. Anti-inflammatory and analgesic effects of the marine-derived compound comaparvin isolated from the crinoid Comanthus bennetti. Molecules 2014, 19, 14667-14686. [CrossRef] [PubMed]

193. Huang, T.Z.; Chen, B.W.; Huang, C.Y.; Hwang, T.L.; Uvarani, C.; Dai, C.F.; Sung, P.J.; Su, J.H.; Sheu, J.H. Eunicellin-based diterpenoids, hirsutalins S-V, from the Formosan soft coral Cladiella hirsuta. Mar. Drugs 2015, 13, 2757-2769. [CrossRef] [PubMed]

194. Huang, T.Z.; Chen, B.W.; Huang, C.Y.; Hwang, T.L.; Dai, C.F.; Sheu, J.H. Eunicellin-based diterpenoids, hirsutalins N-R, from the formosan soft coral Cladiella hirsuta. Mar. Drugs 2014, 12, 2446-2457. [CrossRef] [PubMed]

195. Chen, B.W.; Uvarani, C.; Huang, C.Y.; Hwang, T.L.; Dai, C.F.; Sheu, J.H. New anti-inflammatory tocopherol-derived metabolites from the Taiwanese soft coral Cladiella hirsuta. Bioorg. Med. Chem. Lett. 2015, 25, 92-95. [CrossRef]

196. Tsai, T.C.; Chen, H.Y.; Sheu, J.H.; Chiang, M.Y.; Wen, Z.H.; Dai, C.F.; Su, J.H. Structural elucidation and structure-anti-inflammatory activity relationships of cembranoids from cultured soft corals Sinularia sandensis and Sinularia flexibilis. J. Agric. Food Chem. 2015, 63, 7211-7218. [CrossRef]

197. TSAI, C.R.; Huang, C.Y.; Chen, B.W.; Tsai, Y.Y.; Shih, S.P.; Hwang, T.L.; Dai, C.F.; Wang, S.Y.; Sheu, J.H. New bioactive steroids from the soft coral Klyxum flaccidum. RSC Adv. 2015, 5, 12546-12554. [CrossRef]

198. Lee, Y.N.; Tai, C.J.; Hwang, T.L.; Sheu, J.H. Krempfielins N-P, new anti-inflammatory eunicellins from a Taiwanese soft coral Cladiella krempfi. Mar. Drugs 2014, 12, 1148-1156. [CrossRef]

199. Tai, C.J.; Chokkalingam, U.; Cheng, Y.; Shih, S.P.; Lu, M.C.; Su, J.H.; Hwang, T.L.; Sheu, J.H. Krempfielins $\mathrm{Q}$ and R, two new eunicellin-based diterpenoids from the soft coral Cladiella krempfi. Int. J. Mol. Sci. 2014, 15, 21865-21874. [CrossRef]

200. Fang, H.Y.; Chokkalingam, U.; Chiou, S.F.; Hwang, T.L.; Chen, S.L.; Wang, W.L.; Sheu, J.H. Bioactive chemical constituents from the brown alga Homoeostrichus formosana. Int. J. Mol. Sci. 2014, 16, 736-746. [CrossRef]

201. Wang, W.; Lee, T.G.; Patil, R.S.; Mun, B.; Yang, I.; Kim, H.; Hahn, D.; Won, D.H.; Lee, J.; Lee, Y.; et al. Monanchosterols A and B, bioactive bicyclosteroids from a Korean sponge Monanchora sp. J. Nat. Prod. 2015, 78, 368-373. [CrossRef]

202. Thao, N.P.; Luyen, B.T.; Koo, J.E.; Kim, S.; Koh, Y.S.; Cuong, N.X.; Nam, N.H.; Van, K.P.; Kim, Y.H.; Van, M.C. Anti-inflammatory components of the Vietnamese starfish Protoreaster nodosus. Biol. Res. 2015, 48, 12. [CrossRef] [PubMed]

203. Pudhom, K.; Teerawatananond, T. Rhytidenones A-F, Spirobisnaphthalenes from Rhytidhysteron sp. AS21B, an Endophytic Fungus. J. Nat. Prod. 2014, 77, 1962-1966. [CrossRef] [PubMed]

204. Lin, W.Y.; Chen, B.W.; Huang, C.Y.; Wen, Z.H.; Sung, P.J.; Su, J.H.; Dai, C.F.; Sheu, J.H. Bioactive cembranoids, sarcocrassocolides P-R, from the Dongsha atoll soft coral Sarcophyton crassocaule. Mar. Drugs 2014, 12, 840-850. [CrossRef]

205. Lin, W.J.; Wu, T.Y.; Su, T.R.; Wen, Z.H.; Chen, J.J.; Fang, L.S.; Wu, Y.C.; Sung, P.J. Terpenoids from the octocoral Sinularia gaweli. Int. J. Mol. Sci. 2015, 16, 19508-19517. [CrossRef] [PubMed]

206. Afiyatullov, S.S.; Leshchenko, E.V.; Sobolevskaya, M.P.; Denisenko, V.A.; Kirichuk, N.N.; Khudyakova, Y.V.; Hoai, T.; Dmitrenok, P.S.; Menchinskaya, E.S.; Pislyagin, E.A.; et al. New eudesmane sesquiterpenes from the marine-derived fungus Penicillium thomii. Phytochem. Lett. 2015, 14, 209-214. [CrossRef] 
207. Lin, K.H.; Tseng, Y.J.; Chen, B.W.; Hwang, T.L.; Chen, H.Y.; Dai, C.F.; Sheu, J.H. Tortuosenes A and B, new diterpenoid metabolites from the Formosan soft coral Sarcophyton tortuosum. Org. Lett. 2014, 16, 1314-1317. [CrossRef]

208. Kwan, J.C.; Liu, Y.; Ratnayake, R.; Hatano, R.; Kuribara, A.; Morimoto, C.; Ohnuma, K.; Paul, V.J.; Ye, T.; Luesch, H. Grassypeptolides as natural inhibitors of dipeptidyl peptidase 8 and T-cell activation. Chembiochem 2014, 15, 799-804. [CrossRef]

209. Wang, Q.; Tang, X.; Luo, X.; de Voogd, N.J.; Li, P.; Li, G. (+)- and (-)-Spiroreticulatine, A Pair of Unusual spiro bisheterocyclic quinoline-imidazole alkaloids from the South China sea sponge Fascaplysinopsis reticulata. Org. Lett. 2015, 17, 3458-3461. [CrossRef]

210. Kicha, A.A.; Kalinovsky, A.I.; Malyarenko, T.V.; Ivanchina, N.V.; Dmitrenok, P.S.; Menchinskaya, E.S.; Yurchenko, E.A.; Pislyagin, E.A.; Aminin, D.L.; Huong, T.T.; et al. Cyclic steroid glycosides from the starfish Echinaster luzonicus: Structures and immunomodulatory activities. J. Nat. Prod. 2015, 78, 1397-1405. [CrossRef]

211. Pislyagin, E.A.; Aminin, D.L.; Silchenko, A.S.; Avilov, S.A.; Andryjashchenko, P.V.; Kalinin, V.I.; Padmakumar, K. Immunomodulatory action of triterpene glycosides isolated from the sea cucumber Actinocucumis typica. Structure-activity relationships. Nat. Prod. Commun. 2014, 9, 771-772. [CrossRef]

212. Wu, Y.Z.; Qiao, F.; Xu, G.W.; Zhao, J.; Teng, J.F.; Li, C.; Deng, W.J. Neuroprotective metabolites from the endophytic fungus Penicillium citrinum of the mangrove Bruguiera gymnorrhiza. Phytochem. Lett. 2015, 12, 148-152. [CrossRef]

213. Hjornevik, L.V.; Froyset, A.K.; Gronset, T.A.; Rungruangsak-Torrissen, K.; Fladmark, K.E. Algal toxin azaspiracid-1 induces early neuronal differentiation and alters peripherin isoform stoichiometry. Mar. Drugs 2015, 13, 7390-7402. [CrossRef] [PubMed]

214. Cavalcante-Silva, L.H.; Falcao, M.A.; Vieira, A.C.; Viana, M.D.; de Araujo-Junior, J.X.; Sousa, J.C.; da Silva, T.M.; Barbosa-Filho, J.M.; Noel, F.; de Miranda, G.E.; et al. Assessment of mechanisms involved in antinociception produced by the alkaloid caulerpine. Molecules 2014, 19, 14699-14709. [CrossRef] [PubMed]

215. Kasheverov, I.E.; Shelukhina, I.V.; Kudryavtsev, D.S.; Makarieva, T.N.; Spirova, E.N.; Guzii, A.G.; Stonik, V.A.; Tsetlin, V.I. 6-bromohypaphorine from marine nudibranch mollusk Hermissenda crassicornis is an agonist of human alpha7 nicotinic acetylcholine receptor. Mar. Drugs 2015, 13, 1255-1266. [CrossRef]

216. Chen, W.F.; Huang, S.Y.; Liao, C.Y.; Sung, C.S.; Chen, J.Y.; Wen, Z.H. The use of the antimicrobial peptide piscidin (PCD)-1 as a novel anti-nociceptive agent. Biomaterials 2015, 53, 1-11. [CrossRef]

217. Wang, S.; Zhao, C.; Liu, Z.; Wang, X.; Liu, N.; Du, W.; Dai, Q. Structural and Functional Characterization of a novel alpha-conotoxin Mr1.7 from Conus marmoreus targeting neuronal nAChR alpha3beta2, alpha9alpha10 and alpha6/alpha3beta2beta3 subtypes. Mar. Drugs 2015, 13, 3259-3275. [CrossRef]

218. Zhou, M.; Wang, L.; Wu, Y.; Liu, J.; Sun, D.; Zhu, X.; Feng, Y.; Qin, M.; Chen, S.; Xu, A. Soluble expression and sodium channel activity of lt16a, a novel framework XVI conotoxin from the M-superfamily. Toxicon 2015, 98, 5-11. [CrossRef]

219. Li, M.; Chang, S.; Yang, L.; Shi, J.; McFarland, K.; Yang, X.; Moller, A.; Wang, C.; Zou, X.; Chi, C.; et al. Conopeptide Vt3.1 preferentially inhibits BK potassium channels containing beta4 subunits via electrostatic interactions. J. Biol. Chem. 2014, 289, 4735-4742. [CrossRef]

220. Lee, S.R.; Pronto, J.R.; Sarankhuu, B.E.; Ko, K.S.; Rhee, B.D.; Kim, N.; Mishchenko, N.P.; Fedoreyev, S.A.; Stonik, V.A.; Han, J. Acetylcholinesterase inhibitory activity of pigment echinochrome A from sea urchin Scaphechinus mirabilis. Mar. Drugs 2014, 12, 3560-3573. [CrossRef]

221. Yamagishi, M.; Hosoda-Yabe, R.; Tamai, H.; Konishi, M.; Imamura, A.; Ishida, H.; Yabe, T.; Ando, H.; Kiso, M. Structure-activity relationship study of the neuritogenic potential of the glycan of starfish ganglioside LLG-3 (double dagger). Mar. Drugs 2015, 13, 7250-7274. [CrossRef]

222. Cassiano, C.; Esposito, R.; Tosco, A.; Zampella, A.; D’Auria, M.V.; Riccio, R.; Casapullo, A.; Monti, M.C. Heteronemin, a marine sponge terpenoid, targets TDP-43, a key factor in several neurodegenerative disorders. Chem. Commun. 2014, 50, 406-408. [CrossRef] [PubMed]

223. Bourne, Y.; Sulzenbacher, G.; Radic, Z.; Araoz, R.; Reynaud, M.; Benoit, E.; Zakarian, A.; Servent, D.; Molgo, J.; Taylor, P.; et al. Marine macrocyclic imines, pinnatoxins A and G: Structural determinants and functional properties to distinguish neuronal alpha7 from muscle alpha1(2)betagammadelta nAChRs. Structure 2015, 23, 1106-1115. [CrossRef] [PubMed] 
224. Rodriguez, A.A.; Salceda, E.; Garateix, A.G.; Zaharenko, A.J.; Peigneur, S.; Lopez, O.; Pons, T.; Richardson, M.; Diaz, M.; Hernandez, Y.; et al. A novel sea anemone peptide that inhibits acid-sensing ion channels. Peptides 2014, 53, 3-12. [CrossRef]

225. Choi, B.W.; Lee, H.S.; Shin, H.C.; Lee, B.H. Multifunctional activity of polyphenolic compounds associated with a potential for Alzheimer's disease therapy from Ecklonia cava. Phytother. Res. 2015, 29, 549-553. [CrossRef] [PubMed]

226. Eltahawy, N.A.; Ibrahim, A.K.; Radwan, M.M.; Zaitone, S.A.; Gomaa, M.; ElSohly, M.A.; Hassanean, H.A.; Ahmed, S.A. Mechanism of action of antiepileptic ceramide from Red sea soft coral Sarcophyton auritum. Bioorg. Med. Chem. Lett. 2015, 25, 5819-5824. [CrossRef] [PubMed]

227. Araoz, R.; Ouanounou, G.; Iorga, B.I.; Goudet, A.; Alili, D.; Amar, M.; Benoit, E.; Molgo, J.; Servent, D. The neurotoxic effect of 13,19-didesmethyl and 13-desmethyl spirolide $C$ phycotoxins is mainly mediated by nicotinic rather than muscarinic acetylcholine receptors. Toxicol. Sci. 2015, 147, 156-167. [CrossRef]

228. Shimizu, H.; Koyama, T.; Yamada, S.; Lipton, S.A.; Satoh, T. Zonarol, a sesquiterpene from the brown algae Dictyopteris undulata, provides neuroprotection by activating the Nrf2/ARE pathway. Biochem. Biophys. Res. Commun. 2015, 457, 718-722. [CrossRef]

229. Tian, L.W.; Feng, Y.; Shimizu, Y.; Pfeifer, T.; Wellington, C.; Hooper, J.N.; Quinn, R.J. Aplysinellamides A-C, bromotyrosine-derived metabolites from an Australian Aplysinella sp. marine sponge. J. Nat. Prod. 2014, 77, 1210-1214. [CrossRef]

230. Franklin, J.B.; Rajesh, R.P. A sleep-inducing peptide from the venom of the Indian cone snail Conus araneosus. Toxicon 2015, 103, 39-47. [CrossRef]

231. Harms, H.; Kehraus, S.; Nesaei-Mosaferan, D.; Hufendieck, P.; Meijer, L.; König, G.M. A beta-42 lowering agents from the marine-derived fungus Dichotomomyces cejpii. Steroids 2015, 104, 182-188. [CrossRef]

232. Neves, J.L.; Lin, Z.; Imperial, J.S.; Antunes, A.; Vasconcelos, V.; Olivera, B.M.; Schmidt, E.W. Small molecules in the cone snail arsenal. Org. Lett. 2015, 17, 4933-4935. [CrossRef] [PubMed]

233. Sirimangkalakitti, N.; Olatunji, O.J.; Changwichit, K.; Saesong, T.; Chamni, S.; Chanvorachote, P.; Ingkaninan, K.; Plubrukarn, A.; Suwanborirux, K. Bromotyrosine alkaloids with acetylcholinesterase inhibitory activity from the Thai sponge Acanthodendrilla sp. Nat. Prod. Commun. 2015, 10, 1945-1949. [CrossRef] [PubMed]

234. Mevers, E.; Matainaho, T.; Allara', M.; Di Marzo, V.; Gerwick, W.H. Mooreamide A: A cannabinomimetic lipid from the marine cyanobacterium Moorea bouillonii. Lipids 2014, 49, 1127-1132. [CrossRef] [PubMed]

235. Bisio, A.; Fedele, E.; Pittaluga, A.; Olivero, G.; Grilli, M.; Chen, J.; Mele, G.; Malafronte, N.; De, T.N.; Leddae, F.; et al. Isolation of hydroxyoctaprenyl-1' $4^{\prime}$-hydroquinone, a new octaprenylhydroquinone from the marine sponge Sarcotragus spinosulus and evaluation of its pharmacological activity on acetylcholine and glutamate release in the rat central nervous system. Nat. Prod. Commun. 2014, 9, 1581-1584. [CrossRef] [PubMed]

236. Nesher, N.; Zlotkin, E.; Hochner, B. The sea anemone toxin AdE-1 modifies both sodium and potassium currents of rat cardiomyocytes. Biochem. J. 2014, 461, 51-59. [CrossRef]

237. Kim, M.J.; Woo, S.W.; Kim, M.S.; Park, J.E.; Hwang, J.K. Anti-photoaging effect of aaptamine in UVB-irradiated human dermal fibroblasts and epidermal keratinocytes. J. Asian Nat. Prod. Res. 2014, 16, 1139-1147. [CrossRef]

238. Minamida, M.; Kumagai, K.; Ulanova, D.; Akakabe, M.; Konishi, Y.; Tominaga, A.; Tanaka, H.; Tsuda, M.; Fukushi, E.; Kawabata, J.; et al. Amphirionin-4 with potent proliferation-promoting activity on bone marrow stromal cells from a marine dinoflagellate Amphidinium species. Org. Lett. 2014, 16, 4858-4861. [CrossRef]

239. Wang, J.Y.; Lee, Y.J.; Chou, M.C.; Chang, R.; Chiu, C.H.; Liang, Y.J.; Wu, L.S. Astaxanthin protects steroidogenesis from hydrogen peroxide-induced oxidative stress in mouse Leydig cells. Mar. Drugs 2015, 13, 1375-1388. [CrossRef]

240. Eguchi, K.; Kato, H.; Fujiwara, Y.; Losung, F.; Mangindaan, R.E.; de Voogd, N.J.; Takeya, M.; Tsukamoto, S. Bastadins, brominated-tyrosine derivatives, suppress accumulation of cholesterol ester in macrophages. Bioorg. Med. Chem. Lett. 2015, 25, 5389-5392. [CrossRef]

241. Kwon, T.H.; Wu, Y.X.; Kim, J.S.; Woo, J.H.; Park, K.T.; Kwon, O.J.; Seo, H.J.; Kim, T.; Park, N.H. 6,6'-Bieckol inhibits adipocyte differentiation through downregulation of adipogenesis and lipogenesis in 3T3-L1 cells. J. Sci. Food Agric. 2015, 95, 1830-1837. [CrossRef] 
242. Alvarez-Mico, X.; Rocha, D.D.; Guimaraes, L.A.; Ambrose, A.; Chapman, E.; Costa-Lotufo, L.V.; La Clair, J.J.; Fenical, W. The hybrid pyrroloisoindolone-dehydropyrrolizine alkaloid (-)-chlorizidine A targets proteins within the glycolytic pathway. Chembiochem 2015, 16, 2002-2006. [CrossRef] [PubMed]

243. Chen, Y.C.; Wen, Z.H.; Lee, Y.H.; Chen, C.L.; Hung, H.C.; Chen, C.H.; Chen, W.F.; Tsai, M.C. Dihydroaustrasulfone alcohol inhibits PDGF-induced proliferation and migration of human aortic smooth muscle cells through inhibition of the cell cycle. Mar. Drugs 2015, 13, 2390-2406. [CrossRef] [PubMed]

244. Lin, S.W.; Huang, S.C.; Kuo, H.M.; Chen, C.H.; Ma, Y.L.; Chu, T.H.; Bee, Y.S.; Wang, E.M.; Wu, C.Y.; Sung, P.J.; et al. Coral-derived compound WA-25 inhibits angiogenesis by attenuating the VEGF/VEGFR2 signaling pathway. Mar. Drugs 2015, 13, 861-878. [CrossRef] [PubMed]

245. Piao, M.J.; Hewage, S.R.; Han, X.; Kang, K.A.; Kang, H.K.; Lee, N.H.; Hyun, J.W. Protective Effect of diphlorethohydroxycarmalol against ultraviolet B radiation-induced DNA damage by inducing the nucleotide excision repair system in HaCaT human keratinocytes. Mar. Drugs 2015, 13, 5629-5641. [CrossRef] [PubMed]

246. Kim, H.K.; Youm, J.B.; Jeong, S.H.; Lee, S.R.; Song, I.S.; Ko, T.H.; Pronto, J.R.; Ko, K.S.; Rhee, B.D.; Kim, N.; et al. Echinochrome A regulates phosphorylation of phospholamban Ser16 and Thr17 suppressing cardiac SERCA2A Ca(2)(+) reuptake. Pfluegers Arch. 2015, 467, 2151-2163. [CrossRef]

247. Jeong, S.H.; Kim, H.K.; Song, I.S.; Noh, S.J.; Marquez, J.; Ko, K.S.; Rhee, B.D.; Kim, N.; Mishchenko, N.P.; Fedoreyev, S.A.; et al. Echinochrome a increases mitochondrial mass and function by modulating mitochondrial biogenesis regulatory genes. Mar. Drugs 2014, 12, 4602-4615. [CrossRef]

248. Jun, Y.J.; Lee, M.; Shin, T.; Yoon, N.; Kim, J.H.; Kim, H.R. Eckol enhances heme oxygenase-1 expression through activation of Nrf2/JNK pathway in HepG2 cells. Molecules 2014, 19, 15638-15652. [CrossRef]

249. Harms, H.; Rempel, V.; Kehraus, S.; Kaiser, M.; Hufendiek, P.; Müller, C.E.; König, G.M. Indoloditerpenes from a marine-derived fungal strain of Dichotomomyces cejpii with antagonistic activity at GPR18 and cannabinoid receptors. J. Nat. Prod. 2014, 77, 673-677. [CrossRef]

250. Liu, D.; Yang, A.; Wu, C.; Guo, P.; Proksch, P.; Lin, W. Lipid-lowering effects of farnesylquinone and related analogues from the marine-derived Streptomyces nitrosporeus. Bioorg. Med. Chem. Lett. 2014, 24, 5288-5293. [CrossRef]

251. Yan, T.; Wu, W.; Su, T.; Chen, J.; Zhu, Q.; Zhang, C.; Wang, X.; Bao, B. Effects of a novel marine natural product: Pyrano indolone alkaloid fibrinolytic compound on thrombolysis and hemorrhagic activities in vitro and in vivo. Arch. Pharm. Res. 2015, 38, 1530-1540. [CrossRef]

252. Mizushina, Y.; Suzuki-Fukudome, H.; Takeuchi, T.; Takemoto, K.; Kuriyama, I.; Yoshida, H.; Kamisuki, S.; Sugawara, F. Formosusin A, a novel specific inhibitor of mammalian DNA polymerase beta from the fungus Paecilomyces formosus. Bioorg. Med. Chem. 2014, 22, 1070-1076. [CrossRef] [PubMed]

253. Kim, K.C.; Piao, M.J.; Zheng, J.; Yao, C.W.; Cha, J.W.; Kumara, M.H.; Han, X.; Kang, H.K.; Lee, N.H.; Hyun, J.W. Fucodiphlorethol $\mathrm{G}$ purified from Ecklonia cava suppresses ultraviolet B radiation-induced oxidative stress and cellular damage. Biomol. Ther. 2014, 22, 301-307. [CrossRef] [PubMed]

254. Kang, N.; Lee, J.H.; Lee, W.; Ko, J.Y.; Kim, E.A.; Kim, J.S.; Heu, M.S.; Kim, G.H.; Jeon, Y.J. Gallic acid isolated from Spirogyra sp. improves cardiovascular disease through a vasorelaxant and antihypertensive effect. Environ. Toxicol. Pharmacol. 2015, 39, 764-772. [CrossRef] [PubMed]

255. Miller, B.; Friedman, A.J.; Choi, H.; Hogan, J.; McCammon, J.A.; Hook, V.; Gerwick, W.H. The marine cyanobacterial metabolite gallinamide A is a potent and selective inhibitor of human cathepsin L. J. Nat. Prod. 2014, 77, 92-99. [CrossRef]

256. Fung, S.Y.; Sofiyev, V.; Schneiderman, J.; Hirschfeld, A.F.; Victor, R.E.; Woods, K.; Piotrowski, J.S.; Deshpande, R.; Li, S.C.; de Voogd, N.J.; et al. Unbiased screening of marine sponge extracts for anti-inflammatory agents combined with chemical genomics identifies girolline as an inhibitor of protein synthesis. ACS Chem. Biol. 2014, 9, 247-257. [CrossRef]

257. Sanchez, J.A.; Alfonso, A.; Leiros, M.; Alonso, E.; Rateb, M.E.; Jaspars, M.; Houssen, W.E.; Ebel, R.; Botana, L.M. Spongionella secondary metabolites regulate store operated calcium entry modulating mitochondrial functioning in SH-SY5Y neuroblastoma cells. Cell. Physiol. Biochem. 2015, 37, 779-792. [CrossRef]

258. Gladkikh, I.; Monastyrnaya, M.; Zelepuga, E.; Sintsova, O.; Tabakmakher, V.; Gnedenko, O.; Ivanov, A.; Hua, K.F.; Kozlovskaya, E. New Kunitz-type HCRG polypeptides from the sea anemone Heteractis crispa. Mar. Drugs 2015, 13, 6038-6063. [CrossRef] 
259. Festa, C.; Cassiano, C.; D'Auria, M.V.; Debitus, C.; Monti, M.C.; De, M.S. Scalarane sesterterpenes from Thorectidae sponges as inhibitors of TDP-43 nuclear factor. Org. Biomol. Chem. 2014, 12, 8646-8655. [CrossRef]

260. Quach, H.T.; Hirano, S.; Fukuhara, S.; Watanabe, T.; Kanoh, N.; Iwabuchi, Y.; Usui, T.; Kataoka, T. Irciniastatin A induces potent and sustained activation of extracellular signal-regulated kinase and thereby promotes ectodomain shedding of tumor necrosis factor receptor 1 in human lung carcinoma A549 cells. Biol. Pharm. Bull. 2015, 38, 941-946. [CrossRef]

261. Kazami, S.; Takaine, M.; Itoh, H.; Kubota, T.; Kobayashi, J.; Usui, T. Iejimalide C is a potent V-ATPase inhibitor, and induces actin disorganization. Biol. Pharm. Bull. 2014, 37, 1944-1947. [CrossRef]

262. DeGroot, D.E.; Franks, D.G.; Higa, T.; Tanaka, J.; Hahn, M.E.; Denison, M.S. Naturally occurring marine brominated indoles are aryl hydrocarbon receptor ligands/agonists. Chem. Res. Toxicol. 2015, 28, 1176-1185. [CrossRef] [PubMed]

263. Shubina, L.K.; Makarieva, T.N.; Yashunsky, D.V.; Nifantiev, N.E.; Denisenko, V.A.; Dmitrenok, P.S.; Dyshlovoy, S.A.; Fedorov, S.N.; Krasokhin, V.B.; Jeong, S.H.; et al. Pyridine nucleosides neopetrosides A and B from a marine Neopetrosia sp. sponge. Synthesis of neopetroside A and its beta-riboside analogue. J. Nat. Prod. 2015, 78, 1383-1389. [CrossRef] [PubMed]

264. Jung, H.A.; Jung, H.J.; Jeong, H.Y.; Kwon, H.J.; Ali, M.Y.; Choi, J.S. Phlorotannins isolated from the edible brown alga Ecklonia stolonifera exert anti-adipogenic activity on 3T3-L1 adipocytes by downregulating C/EBPalpha and PPARgamma. Fitoterapia 2014, 92, 260-269. [CrossRef] [PubMed]

265. Iwamoto, M.; Matsunaga, S.; Oiki, S. Paradoxical one-ion pore behavior of the long beta-helical peptide of marine cytotoxic polytheonamide B. Sci. Rep. 2014, 4, 3636. [CrossRef] [PubMed]

266. Li, Z.S.; Noda, K.; Fujita, E.; Manabe, Y.; Hirata, T.; Sugawara, T. The green algal carotenoid siphonaxanthin inhibits adipogenesis in 3T3-L1 preadipocytes and the accumulation of lipids in white adipose tissue of KK-Ay mice. J. Nutr. 2015, 145, 490-498. [CrossRef]

267. Wu, C.; Chen, R.; Liu, M.; Liu, D.; Li, X.; Wang, S.; Niu, S.; Guo, P.; Lin, W. Spiromastixones inhibit foam cell formation via regulation of cholesterol efflux and uptake in RAW264.7 macrophages. Mar. Drugs 2015, 13, 6352-6365. [CrossRef]

268. Lu, L.; Meehan, M.J.; Gu, S.; Chen, Z.; Zhang, W.; Zhang, G.; Liu, L.; Huang, X.; Dorrestein, P.C.; Xu, Y.; et al. Mechanism of action of thalassospiramides, a new class of calpain inhibitors. Sci. Rep. 2015, 5, 8783. [CrossRef]

269. Zhao, L.Y.; Li, J.; Yuan, F.; Li, M.; Zhang, Q.; Huang, Y.Y.; Pang, J.Y.; Zhang, B.; Sun, F.Y.; Sun, H.S.; et al. Xyloketal B attenuates atherosclerotic plaque formation and endothelial dysfunction in apolipoprotein e deficient mice. Mar. Drugs 2015, 13, 2306-2326. [CrossRef]

270. Su, J.; Chang, C.; Xiang, Q.; Zhou, Z.W.; Luo, R.; Yang, L.; He, Z.X.; Yang, H.; Li, J.; Bei, Y.; et al. Xyloketal B, a marine compound, acts on a network of molecular proteins and regulates the activity and expression of rat cytochrome P450 3a: A bioinformatic and animal study. Drug. Des. Devel. Ther. 2014, 8, 2555-2602.

271. Liang, L.F.; Wang, T.; Cai, Y.S.; He, W.F.; Sun, P.; Li, Y.F.; Huang, Q.; Taglialatela-Scafati, O.; Wang, H.Y.; Guo, Y.W. Brominated polyunsaturated lipids from the Chinese sponge Xestospongia testudinaria as a new class of pancreatic lipase inhibitors. Eur. J. Med. Chem. 2014, 79, 290-297. [CrossRef]

272. Hwang, B.S.; Kim, H.S.; Yih, W.; Jeong, E.J.; Rho, J.R. Acuminolide A: Structure and bioactivity of a new polyether macrolide from dinoflagellate Dinophysis acuminata. Org. Lett. 2014, 16, 5362-5365. [CrossRef] [PubMed]

273. Sun, Y.; Takada, K.; Nogi, Y.; Okada, S.; Matsunaga, S. Lower homologues of ahpatinin, aspartic protease inhibitors, from a marine Streptomyces sp. J. Nat. Prod. 2014, 77, 1749-1752. [CrossRef] [PubMed]

274. Won, T.H.; Kim, C.K.; Lee, S.H.; Rho, B.J.; Lee, S.K.; Oh, D.C.; Oh, K.B.; Shin, J. Amino Acid-derived metabolites from the ascidian Aplidium sp. Mar. Drugs 2015, 13, 3836-3848. [CrossRef] [PubMed]

275. Zhuravleva, O.I.; Sobolevskaya, M.P.; Leshchenko, E.V.; Kirichuk, N.N.; Denisenko, V.A.; Dmitrenok, P.S.; Dyshlovoy, S.A.; Zakharenko, A.M.; Kim, N.Y.; Afiyatullov, S.S. Meroterpenoids from the alga-derived fungi Penicillium thomii Maire and Penicillium lividum Westling. J. Nat. Prod. 2014, 77, 1390-1395. [CrossRef]

276. Ai, W.; Lin, X.P.; Tu, Z.; Tian, X.P.; Lu, X.; Mangaladoss, F.; Zhong, Z.L.; Liu, Y. Axinelline A, a new COX-2 inhibitor from Streptomyces axinellae SCSIO02208. Nat. Prod. Res. 2014, 28, 1219-1224. [CrossRef] 
277. Suzuki, R.; Irie, R.; Harntaweesup, Y.; Tachibana, K.; Holland, P.T.; Harwood, D.T.; Shi, F.; Beuzenberg, V.; Itoh, Y.; Pascal, S.; et al. Brevisulcatic acids, marine ladder-frame polyethers from the red tide dinoflagellate Karenia brevisulcata in New Zealand. Org. Lett. 2014, 16, 5850-5853. [CrossRef]

278. Yang, P.; Liu, D.Q.; Liang, T.J.; Li, J.; Zhang, H.Y.; Liu, A.H.; Guo, Y.W.; Mao, S.C. Bioactive constituents from the green alga Caulerpa racemosa. Bioorg. Med. Chem. 2015, 23, 38-45. [CrossRef]

279. Daletos, G.; de Voogd, N.J.; Müller, W.E.; Wray, V.; Lin, W.; Feger, D.; Kubbutat, M.; Aly, A.H.; Proksch, P. Cytotoxic and protein kinase inhibiting nakijiquinones and nakijiquinols from the sponge Dactylospongia metachromia. J. Nat. Prod. 2014, 77, 218-226. [CrossRef]

280. Mohamed, G.A.; Ibrahim, S.R.M.; Badr, J.M.; Youssef, D.T.A. Didemnaketals D and E, bioactive terpenoids from a Red Sea ascidian Didemnum species. Tetrahedron 2014, 70, 35-40. [CrossRef]

281. Jiao, W.H.; Xu, T.T.; Gu, B.B.; Shi, G.H.; Zhu, Y.; Yang, F.; Han, B.N.; Wang, S.P.; Li, Y.S.; Zhang, W.; et al. Bioactive sesquiterpene quinols and quinones from the marine sponge Dysidea avara. RSC Adv. 2015, 5, 87730-87738. [CrossRef]

282. Zhang, Y.; Fang, H.; Xie, Q.; Sun, J.; Liu, R.; Hong, Z.; Yi, R.; Wu, H. Comparative evaluation of the radical-scavenging activities of fucoxanthin and its stereoisomers. Molecules 2014, 19, 2100-2113. [CrossRef] [PubMed]

283. He, F.; Mai, L.H.; Longeon, A.; Copp, B.R.; Loaec, N.; Bescond, A.; Meijer, L.; Bourguet-Kondracki, M.L. Novel adociaquinone derivatives from the Indonesian sponge Xestospongia sp. Mar. Drugs 2015, 13, 2617-2628. [CrossRef] [PubMed]

284. Yamakuma, M.; Kato, H.; Matsuo, K.; El-Desoky, A.H.; Kawabata, T.; Losung, F.; Mangindaan, R.E.P.; de Voogd, N.J.; Yokosawa, H.; Tsukamoto, S. 1-Hydroxyethylhalenaquinone: A new proteasome inhibitor from the marine sponge Xestospongia sp. Heterocycles 2014, 89, 2605-2610.

285. Ebada, S.S.; Linh, M.H.; Longeon, A.; de Voogd, N.J.; Durieu, E.; Meijer, L.; Bourguet-Kondracki, M.L.; Singab, A.N.; Müller, W.E.; Proksch, P. Dispacamide E and other bioactive bromopyrrole alkaloids from two Indonesian marine sponges of the genus Stylissa. Nat. Prod. Res. 2015, 29, 231-238. [CrossRef]

286. Plisson, F.; Prasad, P.; Xiao, X.; Piggott, A.M.; Huang, X.C.; Khalil, Z.; Capon, R.J. Callyspongisines A-D: Bromopyrrole alkaloids from an Australian marine sponge, Callyspongia sp. Org. Biomol. Chem. 2014, 12, 1579-1584. [CrossRef] [PubMed]

287. Abdjul, D.B.; Yamazaki, H.; Takahashi, O.; Kirikoshi, R.; Mangindaan, R.E.; Namikoshi, M. Two new protein tyrosine phosphatase $1 \mathrm{~B}$ inhibitors, hyattellactones $\mathrm{A}$ and $\mathrm{B}$, from the Indonesian marine sponge Hyattella sp. Bioorg. Med. Chem. Lett. 2015, 25, 904-907. [CrossRef] [PubMed]

288. Piao, S.J.; Jiao, W.H.; Yang, F.; Yi, Y.H.; Di, Y.T.; Han, B.N.; Lin, H.W. New hippolide derivatives with protein tyrosine phosphatase 1B inhibitory activity from the marine sponge Hippospongia lachne. Mar. Drugs 2014, 12, 4096-4109. [CrossRef] [PubMed]

289. Davis, R.A.; Vullo, D.; Supuran, C.T.; Poulsen, S.A. Natural product polyamines that inhibit human carbonic anhydrases. Biomed. Res. Int. 2014, 2014, 374079. [CrossRef] [PubMed]

290. Chianese, G.; Sepe, V.; Limongelli, V.; Renga, B.; D'Amore, C.; Zampella, A.; Taglialatela-Scafati, O.; Fiorucci, S. Incisterols, highly degraded marine sterols, are a new chemotype of PXR agonists. Steroids 2014, 83, 80-85. [CrossRef]

291. Thao, N.P.; Luyen, B.T.; Ngan, N.T.; Dat, L.D.; Cuong, N.X.; Nam, N.H.; Kiem, P.V.; Song, S.B.; Minh, C.V.; Kim, Y.H. Peroxisome proliferator-activated receptor transactivational effects in HepG2 cells of cembranoids from the soft coral Lobophytum crassum Von Marenzeller. Arch. Pharm. Res. 2015, 38, 769-775. [CrossRef]

292. Li, X.L.; He, W.F.; Li, J.; Lan, L.F.; Li, X.W.; Guo, Y.W. New laurane-type sesquiterpenoids from the Chinese red alga Laurencia okamurai Yamada. J. Asian Nat. Prod. Res. 2015, 17, 1146-1152. [CrossRef] [PubMed]

293. Sun, Z.H.; Cai, Y.H.; Fan, C.Q.; Tang, G.H.; Luo, H.B.; Yin, S. Six new tetraprenylated alkaloids from the South China sea gorgonian Echinogorgia pseudossapo. Mar. Drugs 2014, 12, 672-681. [CrossRef] [PubMed]

294. Wu, Z.; Liu, D.; Proksch, P.; Guo, P.; Lin, W. Punctaporonins H-M: Caryophyllene-type sesquiterpenoids from the sponge-associated fungus Hansfordia sinuosae. Mar. Drugs 2014, 12, 3904-3916. [CrossRef] [PubMed]

295. Peng, J.; Gao, H.; Zhang, X.; Wang, S.; Wu, C.; Gu, Q.; Guo, P.; Zhu, T.; Li, D. Psychrophilins E-H and versicotide C, cyclic peptides from the marine-derived fungus Aspergillus versicolor ZLN-60. J. Nat. Prod. 2014, 77, 2218-2223. [CrossRef] 
296. Yang, H.; Liu, D.Q.; Liang, T.J.; Li, J.; Liu, A.H.; Yang, P.; Lin, K.; Yu, X.Q.; Guo, Y.W.; Mao, S.C.; et al. Racemosin C, a novel minor bisindole alkaloid with protein tyrosine phosphatase-1B inhibitory activity from the green alga Caulerpa racemosa. J. Asian Nat. Prod. Res. 2014, 16, 1158-1165. [CrossRef]

297. Cheng, Z.B.; Deng, Y.L.; Fan, C.Q.; Han, Q.H.; Lin, S.L.; Tang, G.H.; Luo, H.B.; Yin, S. Prostaglandin Derivatives: Nonaromatic phosphodiesterase-4 inhibitors from the soft coral Sarcophyton ehrenbergi. J. Nat. Prod. 2014, 77, 1928-1936. [CrossRef]

298. Liang, L.F.; Kurtan, T.; Mandi, A.; Gao, L.X.; Li, J.; Zhang, W.; Guo, Y.W. Sarsolenane and capnosane diterpenes from the Hainan soft coral Sarcophyton trocheliophorum Marenzeller as PTP1B inhibitors. Eur. J. Org. Chem. 2014, 2014, 1841-1847. [CrossRef]

299. Qin, C.; Lin, X.; Lu, X.; Wan, J.; Zhou, X.; Liao, S.; Tu, Z.; Xu, S.; Liu, Y. Sesquiterpenoids and xanthones derivatives produced by sponge-derived fungus Stachybotry sp. HH1 ZSDS1F1-2. J. Antibiot. 2015, 68, 121-125. [CrossRef]

300. Kurihara, H.; Kagawa, Y.; Konno, R.; Kim, S.M.; Takahashi, K. Lipoxygenase inhibitors derived from marine macroalgae. Bioorg. Med. Chem. Lett. 2014, 24, 1383-1385. [CrossRef]

301. Hartmann, A.; Gostner, J.; Fuchs, J.E.; Chaita, E.; Aligiannis, N.; Skaltsounis, L.; Ganzera, M. Inhibition of collagenase by mycosporine-like amino acids from marine sources. Planta Med. 2015, 81, 813-820. [CrossRef]

302. Yang, B.; Wei, X.; Huang, J.; Lin, X.; Liu, J.; Liao, S.; Wang, J.; Zhou, X.; Wang, L.; Liu, Y. Sinulolides A-H, new cyclopentenone and butenolide derivatives from soft coral Sinularia sp. Mar. Drugs 2014, 12, 5316-5327. [CrossRef] [PubMed]

303. Li, Y.; Wu, C.; Liu, D.; Proksch, P.; Guo, P.; Lin, W. Chartarlactams A-P, phenylspirodrimanes from the sponge-associated fungus Stachybotrys chartarum with antihyperlipidemic activities. J. Nat. Prod. 2014, 77, 138-147. [CrossRef] [PubMed]

304. Noda, A.; Sakai, E.; Kato, H.; Losung, F.; Mangindaan, R.E.; de Voogd, N.J.; Yokosawa, H.; Tsukamoto, S. Strongylophorines, meroditerpenoids from the marine sponge Petrosia corticata, function as proteasome inhibitors. Bioorg. Med. Chem. Lett. 2015, 25, 2650-2653. [CrossRef] [PubMed]

305. Gong, J.; Sun, P.; Jiang, N.; Riccio, R.; Lauro, G.; Bifulco, G.; Li, T.J.; Gerwick, W.H.; Zhang, W. New steroids with a rearranged skeleton as (h)P300 inhibitors from the sponge Theonella swinhoei. Org. Lett. 2014, 16, 2224-2227. [CrossRef] [PubMed]

306. He, W.F.; Yao, L.G.; Liu, H.L.; Guo, Y.W. Thunberol, a new sterol from the Chinese brown alga Sargassum thunbergii. J. Asian Nat. Prod. Res. 2014, 16, 685-689. [CrossRef] [PubMed]

307. Centko, R.M.; Steino, A.; Rosell, F.I.; Patrick, B.O.; de Voogd, N.; Mauk, A.G.; Andersen, R.J. Indoleamine 2,3-dioxygenase inhibitors isolated from the sponge Xestospongia vansoesti: Structure elucidation, analogue synthesis, and biological activity. Org. Lett. 2014, 16, 6480-6483. [CrossRef] [PubMed]

308. Makarieva, T.N.; Ogurtsova, E.K.; Denisenko, V.A.; Dmitrenok, P.S.; Tabakmakher, K.M.; Guzii, A.G.; Pislyagin, E.A.; Es'kov, A.A.; Kozhemyako, V.B.; Aminin, D.L.; et al. Urupocidin A: A new, inducing iNOS expression bicyclic guanidine alkaloid from the marine sponge Monanchora pulchra. Org. Lett. 2014, 16, 4292-4295. [CrossRef] [PubMed]

309. Sakai, E.; Kato, H.; Rotinsulu, H.; Losung, F.; Mangindaan, R.E.; de Voogd, N.J.; Yokosawa, H.; Tsukamoto, S. Variabines A and B: New beta-carboline alkaloids from the marine sponge Luffariella variabilis. J. Nat. Med. 2014, 68, 215-219. [CrossRef]

310. Inuzuka, T.; Yamamoto, K.; Iwasaki, A.; Ohno, O.; Suenaga, K.; Kawazoe, Y.; Uemura, D. An inhibitor of the adipogenic differentiation of 3T3-L1 cells, yoshinone A. and its analogs isolated from the marine cyonobacterium Leptolyngbya sp. Tetrahedron Lett. 2014, 55, 6711-6714. [CrossRef]

311. Blunt, J.W.; Copp, B.R.; Keyzers, R.A.; Munro, M.H.; Prinsep, M.R. Marine natural products. Nat. Prod. Rep. 2016, 33, 382-431. [CrossRef]

312. Blunt, J.W.; Copp, B.R.; Keyzers, R.A.; Munro, M.H.; Prinsep, M.R. Marine natural products. Nat. Prod. Rep. 2017, 34, 235-294. [CrossRef] [PubMed]

313. Cheung, R.C.; Ng, T.B.; Wong, J.H. Marine Peptides: Bioactivities and Applications. Mar. Drugs 2015, 13, 4006-4043. [CrossRef] [PubMed]

314. Elissawy, A.M.; El-Shazly, M.; Ebada, S.S.; Singab, A.B.; Proksch, P. Bioactive terpenes from marine-derived fungi. Mar. Drugs 2015, 13, 1966-1992. [CrossRef] [PubMed] 
315. Manivasagan, P.; Kang, K.H.; Sivakumar, K.; Li-Chan, E.C.; Oh, H.M.; Kim, S.K. Marine actinobacteria: An important source of bioactive natural products. Environ. Toxicol. Pharmacol. 2014, 38, 172-188. [CrossRef] [PubMed]

316. Marzec, H.; Blaszczyk, A.; Felczykowska, A.; Hohlfeld, N.; Kobos, J. Baltic cyanobacteria-a source of biologically active compounds. Eur. J. Phycol. 2015, 50, 343-360. [CrossRef]

317. Salvador-Reyes, L.A.; Luesch, H. Biological targets and mechanisms of action of natural products from marine cyanobacteria. Nat. Prod. Rep. 2015, 32, 478-503. [CrossRef]

318. Grienke, U.; Silke, J.; Tasdemir, D. Bioactive compounds from marine mussels and their effects on human health. Food Chem. 2014, 142, 48-60. [CrossRef]

319. Derby, C.D. Cephalopod ink: Production, chemistry, functions and applications. Mar. Drugs 2014, 12, $2700-2730$. [CrossRef]

320. Almeida, M.T.; Moritz, M.I.; Capel, K.C.; Perez, C.D.; Schenkel, E.P. Chemical and biological aspects of octocorals from the Brazilian coast. Rev. Brasil. Farmacogn. 2014, 24, 446-467. [CrossRef]

321. Ioca, L.P.; Allard, P.M.; Berlinck, R.G. Thinking big about small beings-the (yet) underdeveloped microbial natural products chemistry in Brazil. Nat. Prod. Rep. 2014, 31, 646-675. [CrossRef]

322. Hu, Y.; Chen, J.; Hu, G.; Yu, J.; Zhu, X.; Lin, Y.; Chen, S.; Yuan, J. Statistical research on the bioactivity of new marine natural products discovered during the 28 years from 1985 to 2012. Mar. Drugs 2015, 13, 202-221. [CrossRef] [PubMed]

323. Trindade, M.; van Zyl, L.J.; Navarro-Fernandez, J.; Abd, E.A. Targeted metagenomics as a tool to tap into marine natural product diversity for the discovery and production of drug candidates. Front. Microbiol. 2015, 6, 890. [CrossRef] [PubMed]

324. Cragg, G.M.; Grothaus, P.G.; Newman, D.J. New horizons for old drugs and drug leads. J. Nat. Prod. 2014, 77, 703-723. [CrossRef] [PubMed]

325. Newman, D.J.; Cragg, G.M. Marine-sourced anti-cancer and cancer pain control agents in clinical and late preclinical development. Mar. Drugs 2014, 12, 255-278. [CrossRef] [PubMed]

326. Gopal, R.; Seo, C.H.; Park, Y. The role of biophysical parameters in the antilipopolysaccharide activities of antimicrobial peptides from marine fish. Mar. Drugs 2014, 12, 1471-1494. [CrossRef] [PubMed]

327. Kang, H.K.; Seo, C.H.; Park, Y. Marine peptides and their anti-infective activities. Mar. Drugs 2015, 13, 618-654. [CrossRef]

328. Ponnappan, N.; Budagavi, D.P.; Yadav, B.K.; Chugh, A. Membrane-active peptides from marine organisms-antimicrobials, cell-penetrating peptides and peptide toxins: Applications and prospects. Probiotics Antimicrob. Proteins 2015, 7, 75-89. [CrossRef]

329. Xu, L.; Meng, W.; Cao, C.; Wang, J.; Shan, W.; Wang, Q. Antibacterial and antifungal compounds from marine fungi. Mar. Drugs 2015, 13, 3479-3513. [CrossRef]

330. Gogineni, V.; Schinazi, R.F.; Hamann, M.T. Role of marine natural products in the genesis of antiviral agents. Chem. Rev. 2015, 115, 9655-9706. [CrossRef]

331. Moghadamtousi, S.Z.; Nikzad, S.; Kadir, H.A.; AbuBakar, S.; Zandi, K. Potential antiviral agents from marine fungi: An overview. Mar. Drugs 2015, 13, 4520-4538. [CrossRef]

332. Torres, F.A.E.; Passalacqua, T.G.; Velasquez, A.M.A.; de Souza, R.A.; Colepicolo, P.; Graminha, M.A.S. New drugs with antiprozoal activity from marine algae: A review. Rev. Bras. Farmacogn. 2014, 24, 265-276. [CrossRef]

333. Franca, P.H.; Barbosa, D.P.; da Silva, D.L.; Ribeiro, E.A.; Santana, A.E.; Santos, B.V.; Barbosa-Filho, J.M.; Quintans, J.S.; Barreto, R.S.; Quintans-Junior, L.J.; et al. Indole alkaloids from marine sources as potential leads against infectious diseases. Biomed. Res. Int. 2014, 2014, 375423. [CrossRef] [PubMed]

334. Ashok, P.; Ganguly, S.; Murugesan, S. Manzamine alkaloids: Isolation, cytotoxicity, antimalarial activity and SAR studies. Drug Discovery Today 2014, 19, 1781-1791. [CrossRef] [PubMed]

335. Gonzalez, Y.; Torres-Mendoza, D.; Jones, G.E.; Fernandez, P.L. Marine diterpenoids as potential anti-inflammatory agents. Mediators. Inflamm. 2015, 2015, 263543. [CrossRef] [PubMed]

336. Talero, E.; Garcia-Maurino, S.; Avila-Roman, J.; Rodriguez-Luna, A.; Alcaide, A.; Motilva, V. Bioactive compounds isolated from microalgae in chronic inflammation and cancer. Mar. Drugs 2015, 13, 6152-6209. [CrossRef]

337. Planes, N.; Caballero-George, C. Marine and soil derived natural products: A new source of novel cardiovascular protective agents targeting the endothelin system. Planta Med. 2015, 81, 630-636. [CrossRef] 
338. Shin, T.; Ahn, M.; Hyun, J.W.; Kim, S.H.; Moon, C. Antioxidant marine algae phlorotannins and radioprotection: A review of experimental evidence. Acta Histochem. 2014, 116, 669-674. [CrossRef]

339. Shindo, K.; Misawa, N. New and rare carotenoids isolated from marine bacteria and their antioxidant activities. Mar. Drugs 2014, 12, 1690-1698. [CrossRef]

340. Maeda, H. Nutraceutical effects of fucoxanthin for obesity and diabetes therapy: A review. J. Oleo. Sci. 2015, 64, 125-132. [CrossRef]

341. Sharifuddin, Y.; Chin, Y.X.; Lim, P.E.; Phang, S.M. Potential bioactive compounds from seaweed for diabetes management. Mar. Drugs 2015, 13, 5447-5491. [CrossRef]

342. Wu, H.; Niu, H.; Shao, A.; Wu, C.; Dixon, B.J.; Zhang, J.; Yang, S.; Wang, Y. Astaxanthin as a potential neuroprotective agent for neurological diseases. Mar. Drugs 2015, 13, 5750-5766. [CrossRef] [PubMed]

343. Lago, J.; Rodriguez, L.P.; Blanco, L.; Vieites, J.M.; Cabado, A.G. Tetrodotoxin, an Extremely Potent Marine Neurotoxin: Distribution, Toxicity, Origin and Therapeutical Uses. Mar. Drugs 2015, 13, 6384-6406. [CrossRef] [PubMed]

344. Choi, D.Y.; Choi, H. Natural products from marine organisms with neuroprotective activity in the experimental models of Alzheimer's disease, Parkinson's disease and ischemic brain stroke: Their molecular targets and action mechanisms. Arch. Pharm. Res. 2015, 38, 139-170. [CrossRef] [PubMed]

345. Leiros, M.; Alonso, E.; Rateb, M.E.; Houssen, W.E.; Ebel, R.; Jaspars, M.; Alfonso, A.; Botana, L.M. Gracilins: Spongionella-derived promising compounds for Alzheimer disease. Neuropharmacology 2015, 93, 285-293. [CrossRef]

346. Russo, P.; Kisialiou, A.; Lamonaca, P.; Moroni, R.; Prinzi, G.; Fini, M. New drugs from marine organisms in Alzheimer's disease. Mar. Drugs 2016, 14, 5. [CrossRef]

347. Thomas, N.V.; Manivasagan, P.; Kim, S.K. Potential matrix metalloproteinase inhibitors from edible marine algae: A review. Environ. Toxicol. Pharmacol. 2014, 37, 1090-1100. [CrossRef]

348. Beesoo, R.; Neergheen-Bhujun, V.; Bhagooli, R.; Bahorun, T. Apoptosis inducing lead compounds isolated from marine organisms of potential relevance in cancer treatment. Mutat. Res. 2014, 768, 84-97. [CrossRef]

349. Mishra, A.; Tandon, R.; Kesarwani, S.; Singh, R.; Tiwari, G.L. Emerging applications of cyanobacterial ultraviolet protecting compound scytonemin. J. Appl. Phycol. 2015, 27, 1045-1051. [CrossRef]

350. Gammone, M.A.; D'Orazio, N. Anti-obesity activity of the marine carotenoid fucoxanthin. Mar. Drugs 2015, 13, 2196-2214. [CrossRef]

351. Ambati, R.R.; Phang, S.M.; Ravi, S.; Aswathanarayana, R.G. Astaxanthin: Sources, extraction, stability, biological activities and its commercial applications-a review. Mar. Drugs 2014, 12, 128-152. [CrossRef]

352. Vazquez-Rodriguez, S.; Matos, M.J.; Borges, F.; Uriarte, E.; Santana, L. Bioactive coumarins from marine sources: Origin, structural features and pharmacological properties. Curr. Top. Med. Chem. 2015, 15, 1755-1766. [CrossRef] [PubMed]

(C) 2019 by the authors. Licensee MDPI, Basel, Switzerland. This article is an open access article distributed under the terms and conditions of the Creative Commons Attribution (CC BY) license (http://creativecommons.org/licenses/by/4.0/). 